\section{Pacific Northwest}

National Laboratory

Operated by Battelle for the

U.S. Department of Energy

\title{
Evaluation and Testing of Noble Metals Surrogates
}

S.K. Sundaram

A.R. Cooper

J. Holbrock
B. MacIsaac

C. Tschauner

September 2002

Prepared for the U.S. Department of Energy under Contract DE-AC06-76RL01830 


\section{DISCLAIMER}

This report was prepared as an account of work sponsored by an agency of the United States Government. Neither the United States Government nor any agency thereof, nor Battelle Memorial Institute, nor any of their employees, makes any warranty, expressed or implied, or assumes any legal liability or responsibility for the accuracy, completeness, or usefulness of any information, apparatus, product, or process disclosed, or represents that its use would not infringe privately owned rights. Reference herein to any specific commercial product, process, or service by trade name, trademark, manufacturer, or otherwise does not necessarily constitute or imply its endorsement, recommendation, or favoring by the United States Government or any agency thereof, or Battelle Memorial Institute. The views and opinions of authors expressed herein do not necessarily state or reflect those of the United States Government or any agency thereof.

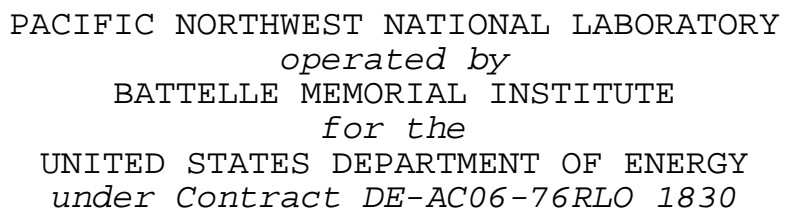

Printed in the United States of America

Available to DOE and DOE contractors from the

Office of Scientific and Technical Information, P.O. Box 62, Oak Ridge, TN 37831;

prices available from (615) 576-8401.

Available to the public from the National Technical Information Service, U.S. Department of Commerce, 5285 Port Royal Rd., Springfield, VA 22161 
PNNL-13681

\title{
Evaluation and Testing of Noble Metals Surrogates
}

\author{
S. K. Sundaram Brett C. MacIsaac \\ Alan R. Cooper Candice H. Trader \\ Jeremy J. Holbrook \\ Pacific Northwest National Laboratory, Richland, WA 99352
}

September 2002

Prepared for the U.S. Department of Energy

under Contract DE-AC06-76RLO 1830.

Pacific Northwest National Laboratory

Richland, Washington 99352 


\begin{abstract}
This report summarizes the results of testing and evaluation of noble metal surrogates that will support testing of noble metals in melters. The candidate system, potential surrogates, model glass systems, and test conditions have been chosen based on the existing reported data in literature as well as expertise existing at various sites, thermodynamics, physical properties, and cost of materials. The methodology involves testing interaction of $\mathrm{RuO}_{2}$ and $\mathrm{WO}_{3}$ and other surrogates in the test melt followed by characterization of the bulk glass and oxide-glass melt interfaces. The report explains different techniques used for studying settling, crystallization, rheology, and partitioning of noble metals or surrogates or spinel phases in the selected systems. The report presents and discusses how these results support the selection of the suitable surrogate for $\mathrm{RuO}_{2}$. Finally the report concludes with identification of the best-suited surrogate (solubility and redox surrogate $\mathrm{WO}_{3}$ and conductivity surrogate $\mathrm{Cr}_{2} \mathrm{O}_{3}$ ) proposed and makes suitable recommendations for the follow up melter test activities.
\end{abstract}




\section{Summary}

The formation and settling of noble metals in high-level waste (HLW) glass melts poses a major challenge to the vitrification technology. Precipitation of noble metals in these joule-heated melters can lead to operational difficulties and premature failure of the melter through electrical shorting and enhanced corrosion of the electrodes. Additionally, the noble metals are known to act as nucleation sites for the precipitation and growth of spinel (crystalline) phases, which in turn will settle to the bottom of the melter and cause the viscosity of the melt to increase in that region. Use of actual noble metals and compounds for melter testing is not cost effective. Pacific Northwest National Laboratory (PNNL) and Savannah River Technology Center (SRTC) have undertaken efforts to identify suitable surrogates for noble metals to facilitate extensive melter testing that will provide key processing data. This report summarizes the results of the experimental testing evaluation of noble metal surrogates performed at PNNL.

Initial selection of model glass test systems, noble metals, potential surrogates, and test conditions was done based on the existing data and expertise at DOE various sites (West Valley, Savannah River, and Hanford), thermodynamics, physical properties, and cost of materials. A simplified version of HLW glass (MS-7) and a modified neutralized caustic acid waste (NCAW) glass compositions were used in this study. Overview of existing literature on noble metals in waste melts and melter testing indicated that $\mathrm{RuO}_{2}$ was the most commonly detected phase present. Hence, the present testing was focused at $\mathrm{RuO}_{2}$ and its potential suitable surrogates. The potential surrogates considered and studied were $\mathrm{WO}_{3}, \mathrm{Cr}_{2} \mathrm{O}_{3}$, $\mathrm{NiCr}_{2} \mathrm{O}_{4}$, and Inconel 600. From chemical stability and density perspectives, the W-O system showed the promise of serving as a surrogate for $\mathrm{Ru}$ as well as $\mathrm{RuO}_{2} . \mathrm{WO}_{2}\left(12.11 \mathrm{~g} / \mathrm{cm}^{3}\right)$ could act as a surrogate for $\mathrm{Ru}\left(12.30 \mathrm{~g} / \mathrm{cm}^{3}\right)$ under reducing conditions. Alternatively, $\mathrm{WO}_{3}\left(7.20 \mathrm{~g} / \mathrm{cm}^{3}\right)$ could act as a surrogate for $\mathrm{RuO}_{2}\left(6.97 \mathrm{~g} / \mathrm{cm}^{3}\right)$ under oxidizing conditions. Therefore, the surrogate testing was focused at $\mathrm{WO}_{3}$. The testing included: 1) double-crucible settling study, 2) viscosity and rheology, 3) crystallization study, 4) high temperature optical microscopy, and 5) partition study.

Double crucible settling studies indicated more spinel crystals formed at $950^{\circ} \mathrm{C}$ and started settling at $1000^{\circ} \mathrm{C}$, with $\mathrm{RuO}_{2}$ as well as $\mathrm{WO}_{3}$ in MS-7 glass. Figure S. 1 compares the thin section of the inner crucibles with $\mathrm{RuO}_{2}$ and $\mathrm{WO}_{3}$ heat-treated at $900-1000^{\circ} \mathrm{C}$ for $19-13 \mathrm{~h}$. SEM, EDS, and XRD data have supported this observation. XRD data confirmed formation of Trevorite $\left(\mathrm{NiFe}_{2} \mathrm{O}_{4}\right)$ phase. No other major phase was detected. Ru was found to partition readily in the spinel phase, as compared to $\mathrm{W}$.

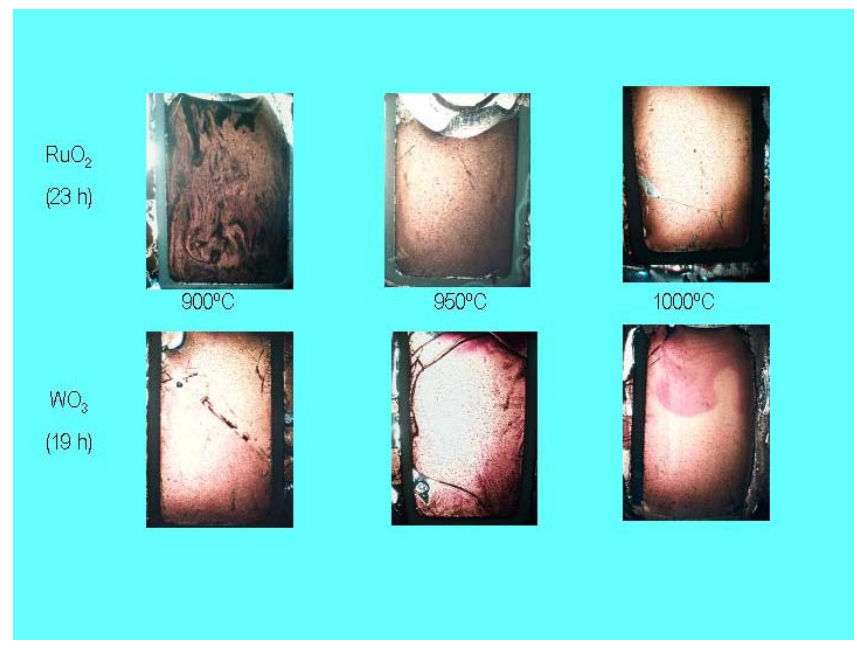

Figure S.1. $\mathrm{RuO}_{2}$ vs. $\mathrm{WO}_{3}-$ Temperature Effect (0.5 wt.\% in MS-7) 
Crystallization study (heat-treatment followed by XRD measurements) showed that addition $(0.5$ wt.\%) of $\mathrm{RuO}_{2}$ or $\mathrm{WO}_{3}$ to MS-7 resulted in formation of Trevorite. Residual undissolved $\mathrm{RuO}_{2}$ was detected in the glass containing $\mathrm{RuO}_{2}$. No $\mathrm{WO}_{3}$ was detected by XRD in the glass containing $\mathrm{WO}_{3}$. The difference was attributed to higher solubility of $\mathrm{WO}_{3}$ in the glass, as compared to $\mathrm{RuO}_{2}$.

An order of magnitude increase in viscosity values was observed as addition of $\mathrm{NiCr}_{2} \mathrm{O}_{4}$ (one of potential surrogates studied in this project) increased from $1 \mathrm{wt} . \%$ to $10 \mathrm{wt} . \%$ in modified NCAW glass melts, as shown in Figure S.2. This also resulted in an increase in shear stress of rotating spindle in rheology testing. This data clearly established the consequences of increased spinel formation and accumulation in this system.

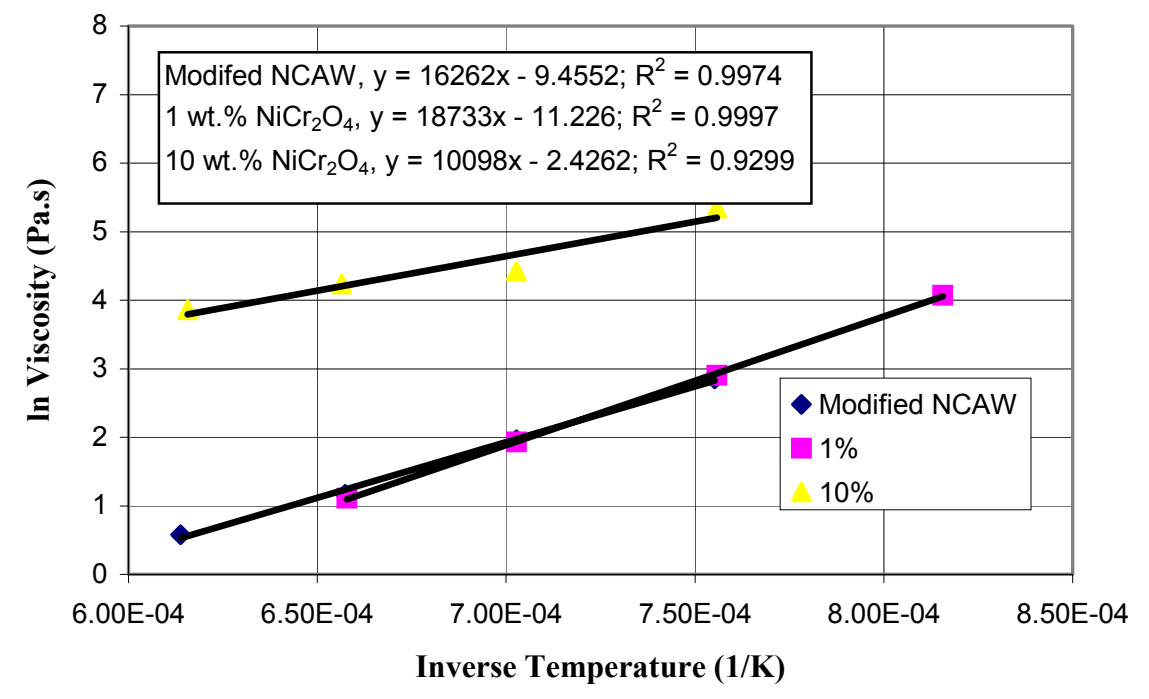

Figure S.2. Effect of Addition of $\mathrm{NiCr}_{2} \mathrm{O}_{4}$ on Viscosity of the Modified-NCAW Melt

High temperature optical microscopy results showed floating nodular aggregates of $\mathrm{RuO}_{2}$ at higher temperature $\left(>900^{\circ} \mathrm{C}\right)$ due to its insolubility in the MS-7 melt (Figure S.3 (a)). On the contrary, $\mathrm{NiCr}_{2} \mathrm{O}_{4}$ dissolved completely in the test melt (Figure S.3 (b)).
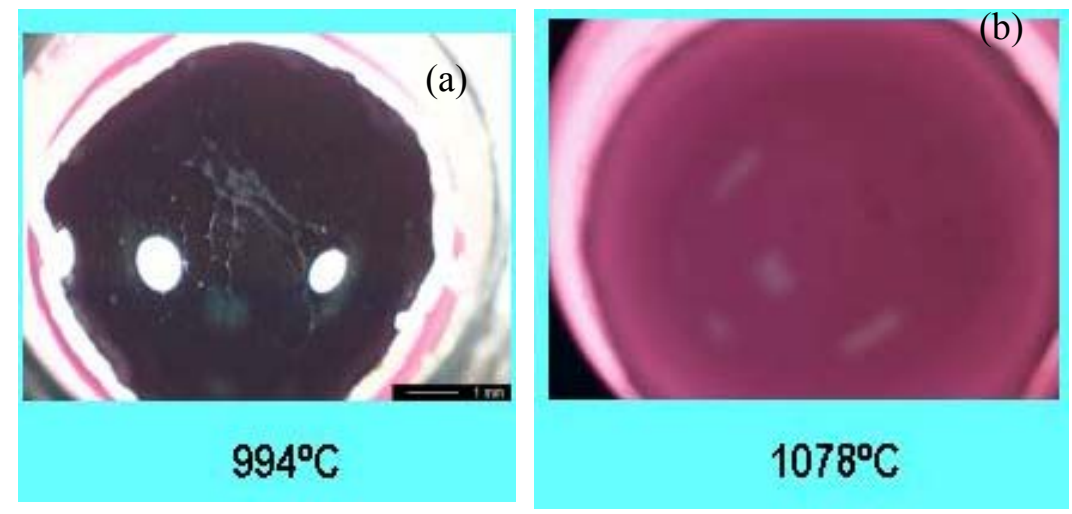

Figure S.3. High Temperature Optical Microscopy of (a) $\mathrm{RuO}_{2}$ and (b) $\mathrm{NiCr}_{2} \mathrm{O}_{4}$ in $\mathrm{MS}-7 \mathrm{Melt}$ 
Partitioning study of noble metal species $\left(\mathrm{Ru}\right.$ and $\mathrm{RuO}_{2}$ ) and the surrogate species $\left(\mathrm{W}\right.$ and $\left.\mathrm{WO}_{3}\right)$ between spinel (nonstoichiometric $\mathrm{MgAl}_{2} \mathrm{O}_{4}$ ) and model glass melt (MS-7) indicated striking similarity between $\mathrm{RuO}_{2}$ and $\mathrm{WO}_{3}$, as shown in Figure $\mathrm{S} .4$ (a) and (b), respectively. The sequence of the events was:

1) The glass melt reacted with the spinel forming a reaction layer at the spinel-glass interfacial region. Some $\mathrm{Ru}$ or $\mathrm{W}$ partitioned in spinel in this reaction layer.

2) Excess $\mathrm{Ru}$ or $\mathrm{W}$ remained near the interfacial region and in bulk glass.

3) Spinel segments began to dislodge from the bulk spinel, drifted into the melt and eventually dissolved into the glass melt.

4) Some $\mathrm{Ru}$-containing and $\mathrm{W}$-rich regions remained in the glass side of the interfacial region.

5) Spinel (either $\mathrm{MgAl}_{2} \mathrm{O}_{4}$ or Trevorite or a combination of these two) recrystallized in the glass melt.
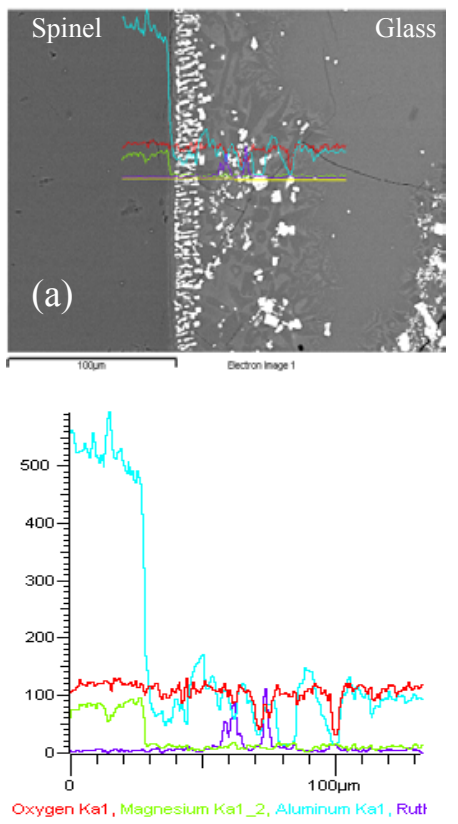
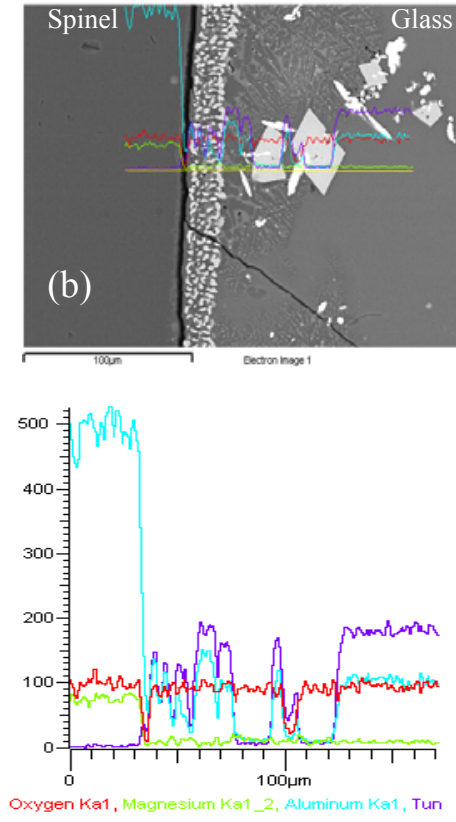

Figure S.4. SEM-EDS of (a) $\mathrm{RuO}_{2}$ and (b) $\mathrm{WO}_{3}$ in MS-7 Melt $\left(0.5\right.$ wt.\%, $\left.1000^{\circ} \mathrm{C}, 23 \mathrm{~h}\right)$

Top: Back-scattered SEM image with line EDS superimposed, Bottom: Line EDS scan 
AC conductivity data clearly indicated that $\mathrm{Cr}_{2} \mathrm{O}_{3}$ showed conductivity data closely matched that of $\mathrm{RuO}_{2}$, as shown in Figure S.5. $\mathrm{Cr}_{2} \mathrm{O}_{3}$ was recommended as a conductivity surrogate.
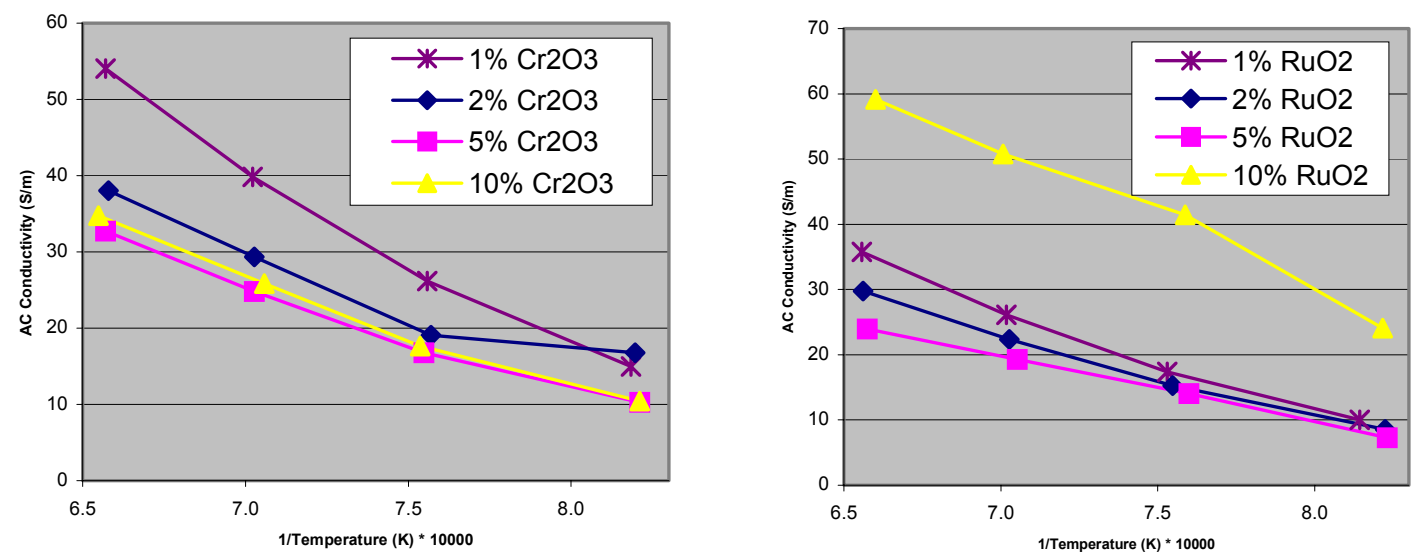

Figure S.5. AC conductivity of $\mathrm{Cr}_{2} \mathrm{O}_{3}$ (left) and $\mathrm{RuO}_{2}$ (right)

From the thermodynamic stability and density perspectives, $\mathrm{RuO}_{2}$ and $\mathrm{WO}_{3}$, showed a good match. Based on our results on these aspects, $\mathrm{WO}_{3}$ was recommended as a chemical surrogate for $\mathrm{RuO}_{2}$. A research-scale melter (RSM) test was also recommended before testing the surrogate in an engineering scale melter. 


\section{Glossary}

$\begin{array}{ll}\eta & \text { viscosity } \\ \text { ASTM } & \text { American Society for Testing and Materials } \\ \text { DOE } & \text { U.S. Department of Energy } \\ \text { DWPF } & \text { Defense Waste Processing Facility } \\ \text { EA } & \text { Environmental Assessment } \\ \text { EDS } & \text { energy dispersive spectroscopy } \\ \text { FY } & \text { Fiscal Year } \\ \text { HAW } & \text { high-activity waste } \\ \text { HLW } & \text { high-level waste } \\ \text { NCAW } & \text { neutralized caustic acid waste } \\ \text { OES } & \text { optical emission spectroscopy } \\ \text { RSM } & \text { research-scale melter } \\ \text { SEM } & \text { scanning electron microscopy } \\ \text { T } & \text { temperature } \\ \text { TFA } & \text { Tanks Focus Area } \\ \text { XRD } & \text { X-ray diffraction }\end{array}$




\section{Acknowledgments}

The authors would like to acknowledge Denny Bickford for technical guidance, Joe Perez and Pavel Hrma for useful discussion, Michael Schweiger and Jarrod Crum for helping the students Candice Trader, Alan Cooper, and Jeremy Holbrook, Craig Habeger for particle size measurements, Jim Coleman for SEM-EDS work, and Nat Canfield and Dave McCready for XRD work. The authors would also like to acknowledge Ron Goles for technical review, Nancy Foote for prompt editing, and William Holtzscheiter for management and guidance. This study was funded by the Department of Energy's

Office of Science and Technology through the Tanks Focus Area. Pacific Northwest National Laboratory is operated for the U.S. Department of Energy by Battelle under Contract DE-AC06-76RLO 1830. 


\section{Contents}

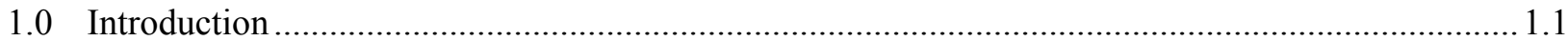

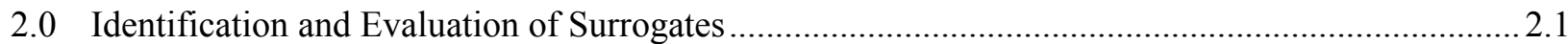

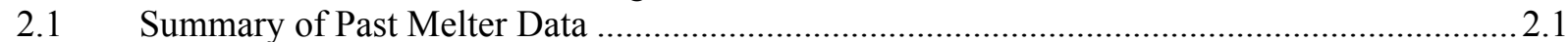

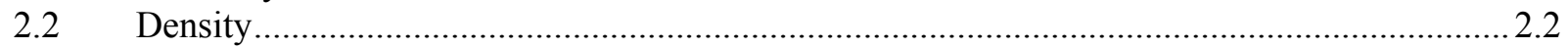

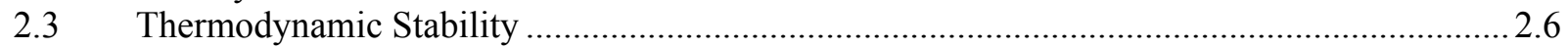

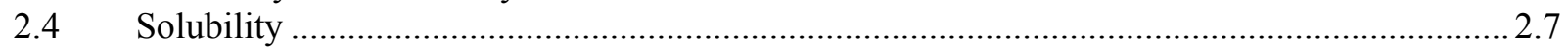

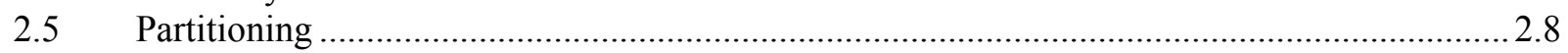

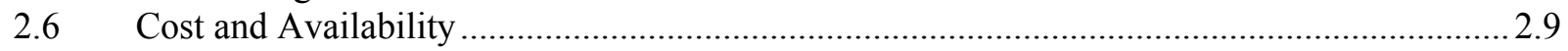

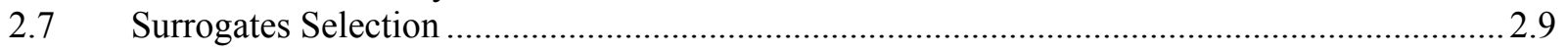

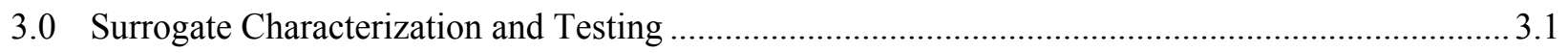

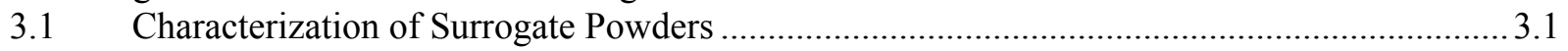

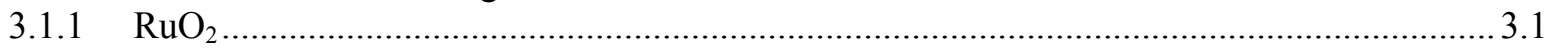

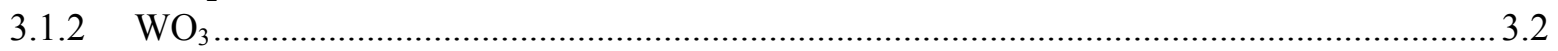

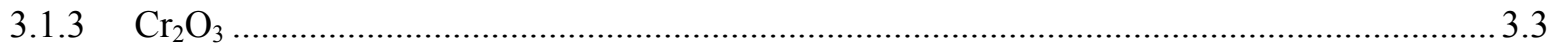

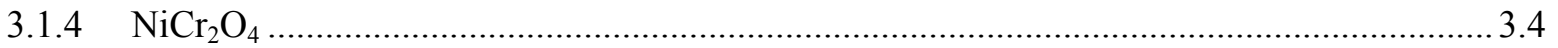

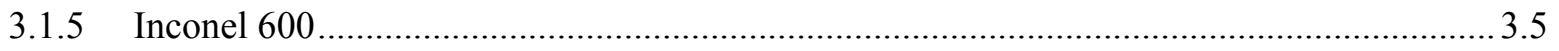

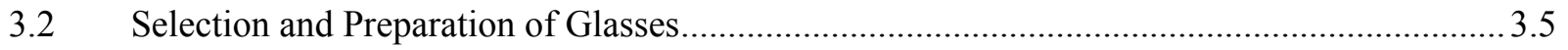

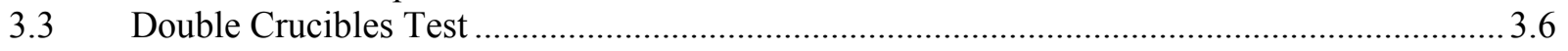

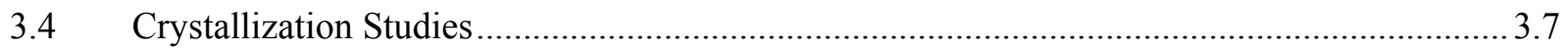

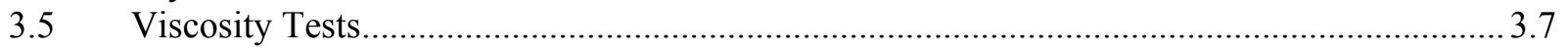

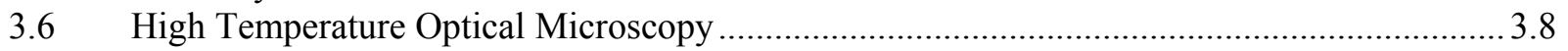

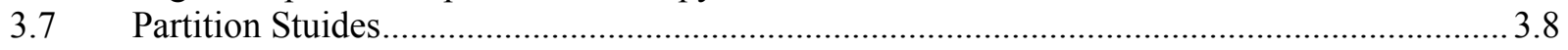

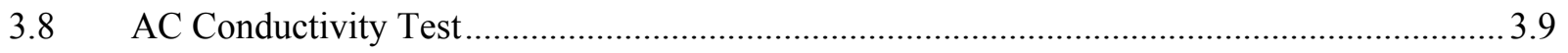

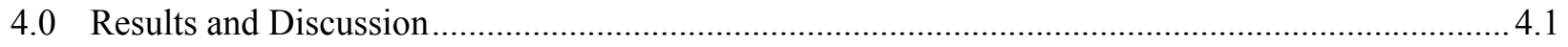

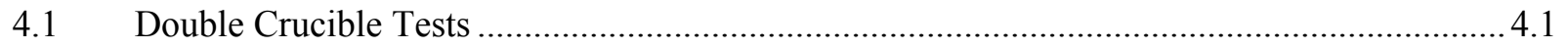

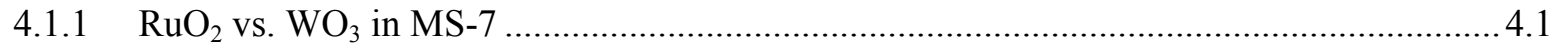

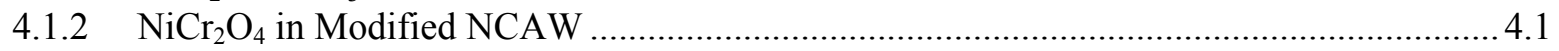

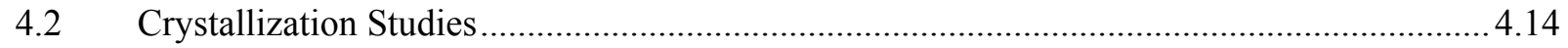

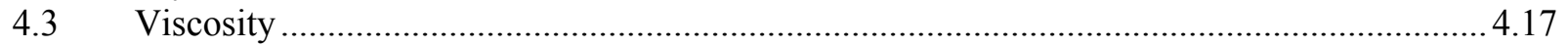

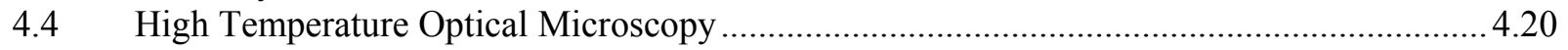

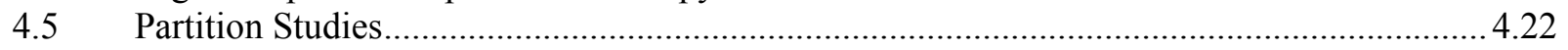

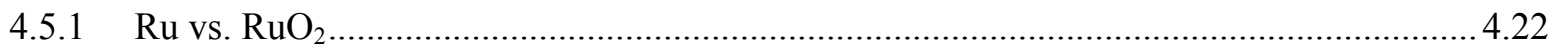

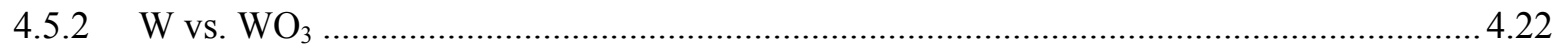

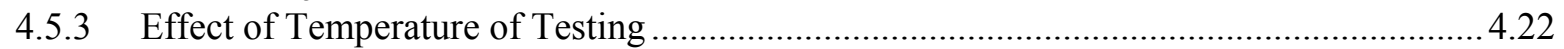

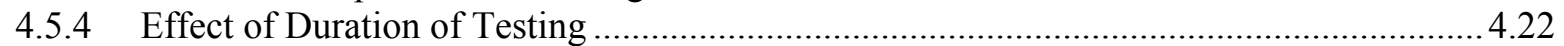

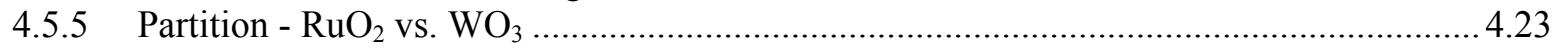

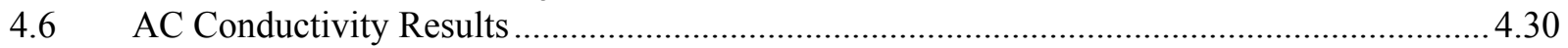

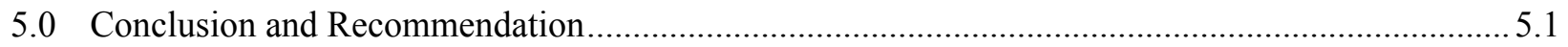

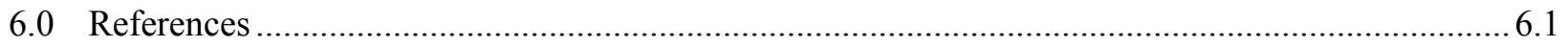




\section{Figures}

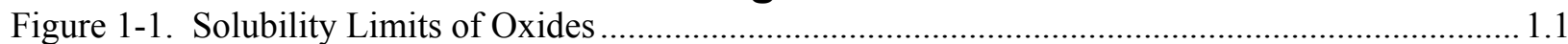

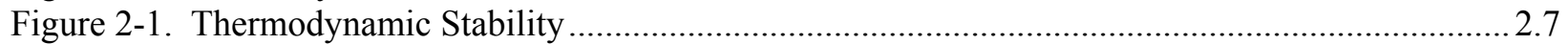

Figure 2-2. The Henry's Law Limit for W in Silicate Melt at $1400^{\circ} \mathrm{C}$ (Ertel et al., 1996) .....................2.8

Figure 3-1. a) Particle Size, b) SEM, c) Point EDS area, and d) EDS Data of $\mathrm{RuO}_{2}$ Powder .................. 3.1

Figure 3-2. a) Particle Size, b) SEM, c) Point EDS area, and d) EDS Data of $\mathrm{WO}_{3}$ Powder................... 3.2

Figure 3-3. a) Particle Size, b) SEM, c) Point EDS area, and d) EDS Data of $\mathrm{Cr}_{2} \mathrm{O}_{3}$ Powder .................3.3

Figure 3-4. a) Particle Size, b) SEM, c) Point EDS area, and d) EDS Data of $\mathrm{NiCr}_{2} \mathrm{O}_{4}$ Powder .............. 3.4

Figure 3-5. a) Particle Size, b) SEM, c) Point EDS area, and d) EDS Data of Inconel 600 Powder ........ 3.5

Figure 3-6. Double Crucible Test (Klouzek et al. 2001) ...................................................................... 3.7

Figure 3-7. Hot Optical Microscopy Stage ........................................................................................ 3.8

Figure 3-8. Capsule and Sample Preparation for Partition Study ........................................................... 3.9

Figure 4-1. $\mathrm{RuO}_{2}$ vs. $\mathrm{WO}_{3}$ - Time Effect $(0.5$ wt.\% in MS-7) .......................................................... 4.2

Figure 4-2. $\mathrm{RuO}_{2}$ vs. $\mathrm{WO}_{3}-$ Temperature Effect $(0.5 \mathrm{wt} \%$ in MS-7) ….............................................. 4.3

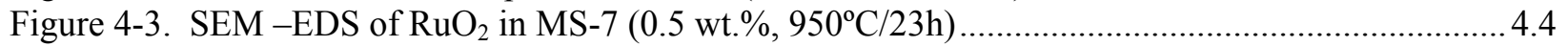

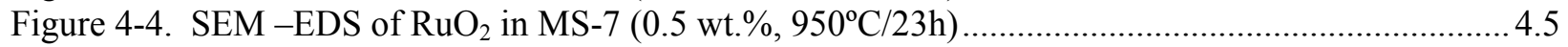

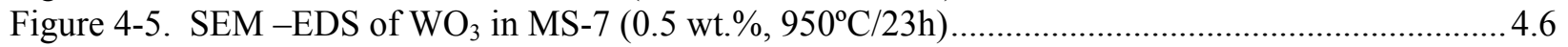

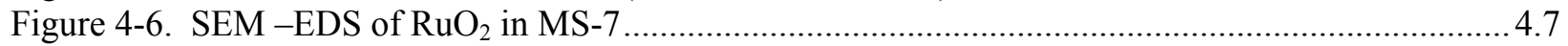

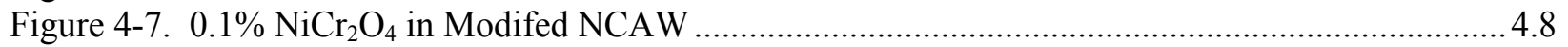

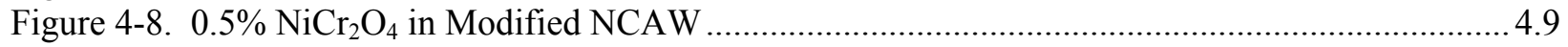

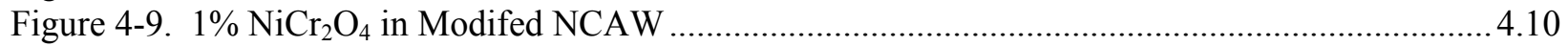

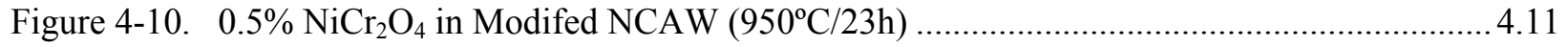

Figure 4-11. $\quad 0.5 \% \mathrm{NiCr}_{2} \mathrm{O}_{4}$ in Modifed NCAW $\left(950^{\circ} \mathrm{C} / 23 \mathrm{~h}\right)$ - Different Region .............................. 4.12

Figure 4-12. $0.5 \% \mathrm{NiCr}_{2} \mathrm{O}_{4}$ in Modifed NCAW $\left(950^{\circ} \mathrm{C} / 23 \mathrm{~h}\right)$ - Different Region ............................... 4.13

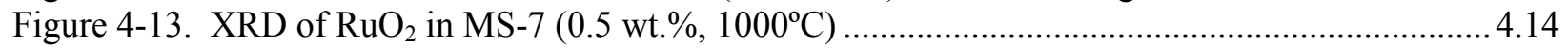

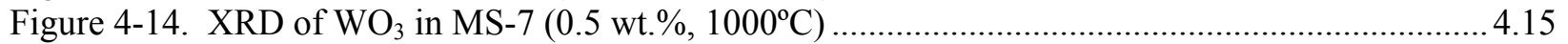

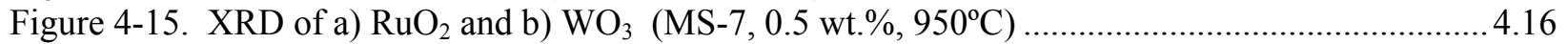

Figure 4-16. Temperature Dependence of Viscosity of Modified NCAW ............................................ 4.17

Figure 4-17. Temperature Dependence of Viscosity of Modified NCAW with 1 wt. $\% \mathrm{NiCr}_{2} \mathrm{O}_{4} \ldots \ldots \ldots .4 .18$

Figure 4-18. Temperature Dependence of Viscosity of Modified NCAW with 10 wt.\% $\mathrm{NiCr}_{2} \mathrm{O}_{4} \ldots \ldots . .4 .18$

Figure 4-19. (a) Shear Stress and (b) Viscosity of Modified NCAW with 10 wt. $\% \mathrm{NiCr}_{2} \mathrm{O}_{4} \ldots \ldots \ldots \ldots \ldots .19$

Figure 4-20. High Temperature Optical Micrographs (1 wt.\% $\mathrm{RuO}_{2}$ in $\left.\mathrm{MS}-7\right)$................................... 4.20

Figure 4-21. High Temperature Optical Micrographs (1 wt.\% $\mathrm{NiCr}_{2} \mathrm{O}_{4}$ in MS-7) ............................ 4.21

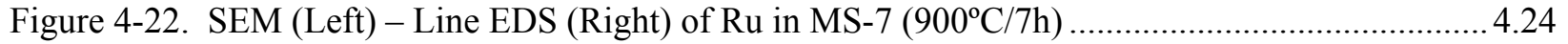

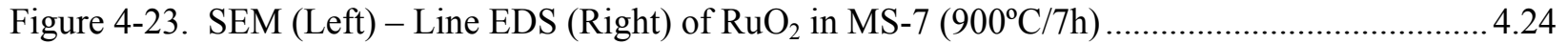

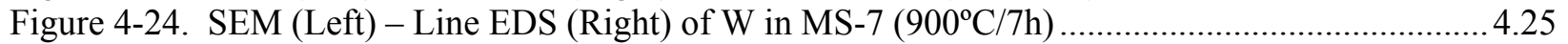

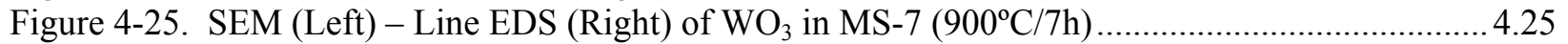

Figure 4-26. SEM (Left) - Line EDS (Right) of $\mathrm{RuO}_{2}$ in MS-7 $\left(900^{\circ} \mathrm{C} / 7 \mathrm{~h}\right)$...................................... 4.26

Figure 4-27. SEM (Left) - Line EDS (Right) of $\mathrm{RuO}_{2}$ in MS-7 $\left(1000^{\circ} \mathrm{C} / 7 \mathrm{~h}\right)$....................................26

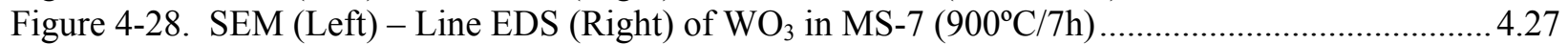

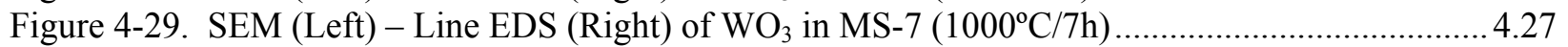

Figure 4-30. SEM (Top) - Line EDS (Bottom) of $\mathrm{RuO}_{2}$ in MS-7 $\left(1000^{\circ} \mathrm{C}\right)$ for (a) $7 \mathrm{~h}$, (b) $15 \mathrm{~h}$, (c) $19 \mathrm{~h}$,

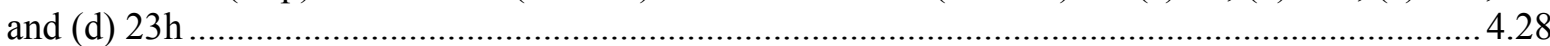

Figure 4-31. SEM (Top) - Line EDS (Bottom) of $\mathrm{WO}_{3}$ in MS-7 $\left(1000^{\circ} \mathrm{C}\right)$ for (a) $7 \mathrm{~h}$, (b) $15 \mathrm{~h}$, (c) $19 \mathrm{~h}$, and

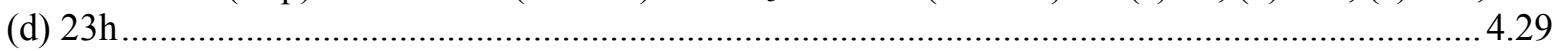

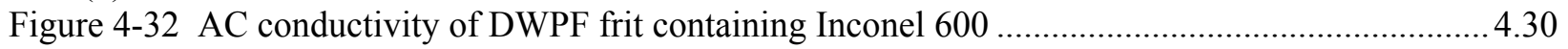

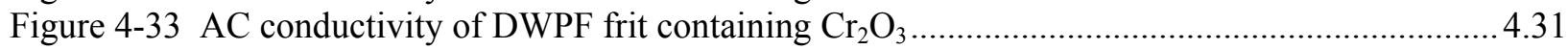

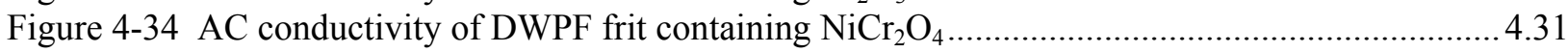

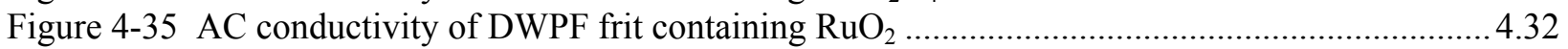

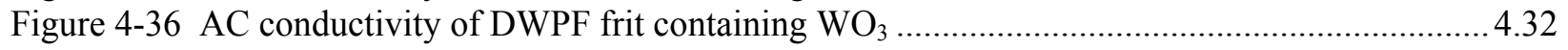




\section{Tables}

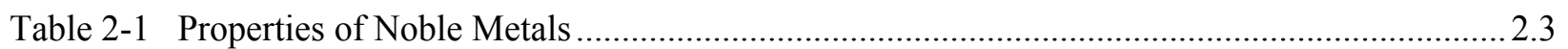

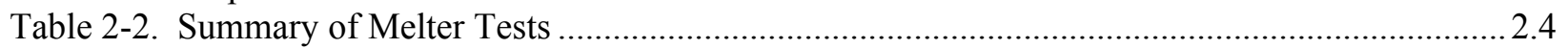

Table 2-3. Potential Surrogates For $\mathrm{RuO}_{2}$ Based On Density $\left(6.97 \mathrm{~g} / \mathrm{cm}^{3} \pm 10 \%\right)$................................. 2.5

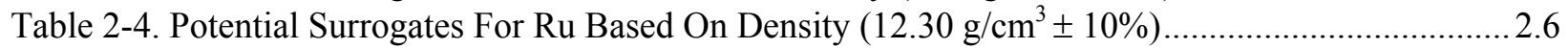

Table 2-5. Summary of Platinum-Group Element Spinel/Melt Partition Coefficients, Run Conditions, and

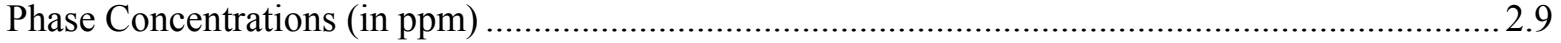

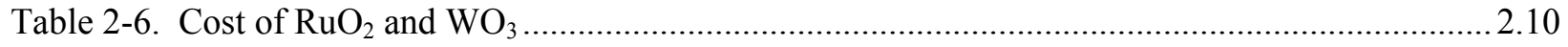

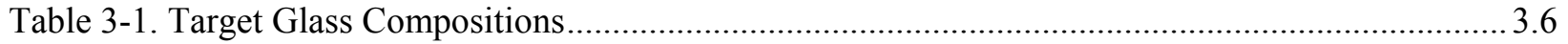

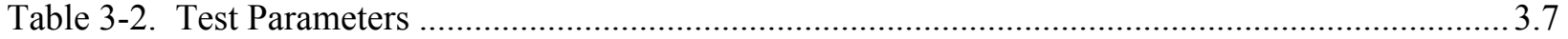




\subsection{Introduction}

The noble metals rhodium $(\mathrm{Rh})$, ruthenium $(\mathrm{Ru})$, and palladium $(\mathrm{Pd})$ are fission products that partition to the waste sludges after the acid wastes from the processing of spent fuel are made alkaline. In some cases these metals can approach concentrations on the order of 0.1 mass $\%$ in the waste sludges, while the solubilities of the metal or metal oxide in glass melts are reported to be about 0.01 mass \%. The actual solubility in the melt depends on the glass composition, redox, and temperature of the melt. The densities of the metal and oxides are substantially higher than the glass melt $\left[\sim 10 \cdot 10^{3} \mathrm{~kg} / \mathrm{m}^{3} \mathrm{vs} .2 .5 \cdot 10^{3}\right.$ $\mathrm{kg} / \mathrm{m}^{3}$ ] and tend to settle to the bottom of the melter. If the accumulation of these metals becomes great enough, a low resistance path for electrical current is established and an electrical short results in premature failure of the melter if no method is present to remove the accumulated metals. This early failure has been a concern at the Savannah River Site, West Valley, and Hanford. In the case of West Valley operations, the power fluctuations observed have been attributed to noble metals accumulation in the melter. A sludge sampler was designed and deployed by Pacific Northwest National Laboratory (PNNL) team.

Actual failure of a glass melter at Dessel, Belgium was attributed to noble metal accumulation and subsequent shorting of the electrodes. Additionally, these noble metals and metal oxides usually precipitate as very fine particles, which serve as excellent nucleation sites for other species in the glass melt that are at their solubility limits, e.g. spinels. Solubility limits of oxides are presented in Figure 1.1. It is known the solubility of noble metals in the glass melts is small (shown as 0 in Figure 1.1). But, solubility studies of noble metals in waste glass melts are limited.

Figure 1-1. Solubility Limits of Oxides

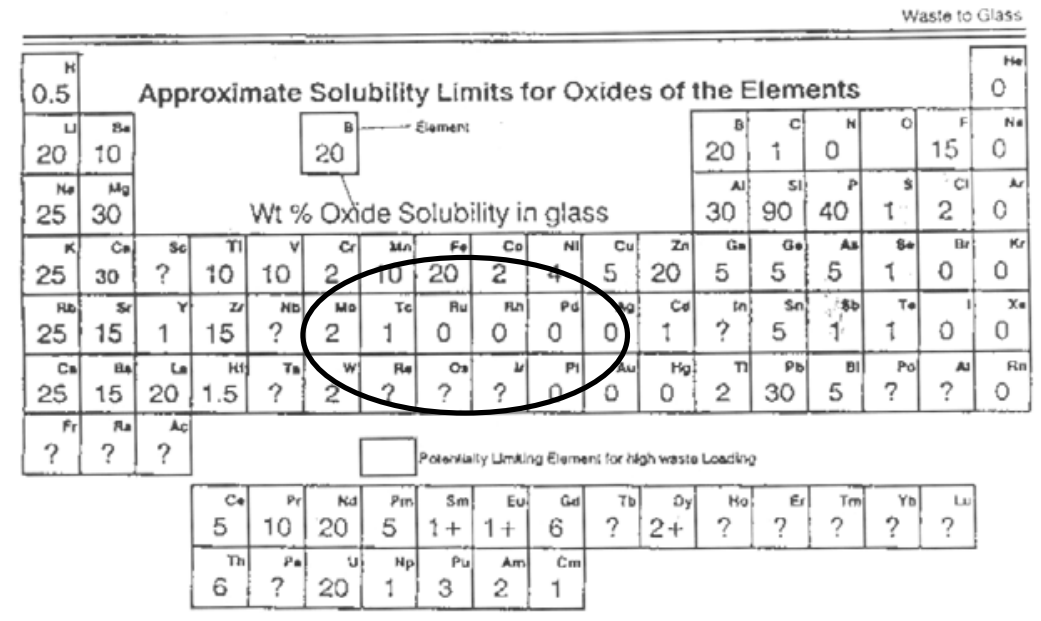

While fundamental understanding of dissolution and structural incorporation of noble metals is still mostly qualitative in nature, significant level of testing has been done in melters in the USA and other countries. The melter data are valuable in the sense they emulate conditions that are close to the actual melter processing conditions and they also provide guidelines for design and scale-up studies. Therefore, it is worthwhile to conduct melter tests to collect necessary processing data.

Use of actual expensive noble metals in melter tests will result in significant impact on cost of tests. Additionally, the noble metals may not be available in a timely manner for testing. Therefore, one 
needs to use inexpensive surrogates for noble metals. In response to this need, the Tanks Focus Area (TFA) supports the present effort. The main objectives of the present task are: 1) Identify potential noble metals surrogates, 2) Evaluate their performances in representative waste glass melts in the laboratory, and 3) Recommend suitable surrogates for testing in melters. This report summarizes the results of the task. 


\subsection{Identification and Evaluation of Surrogates}

A suitable noble metals surrogate needs to meet stringent requirements. Table 2.1 shows a summary of the properties of the noble metals. In identifying and evaluating a surrogate, attempt will be taken to meet as many requirements as possible. We have listed the basic requirements of a suitable noble metals surrogate here:

1. Density of the surrogate

2. Thermodynamic stability of the surrogate

3. Solubility of the surrogate in glass melts

4. Partitioning of the surrogate between glass and crystalline phases

5. Chemical interaction of the surrogate with other waste constituents

6. Interaction of the surrogate with other crystalline phases (e.g., spinels)

7. Availability

8. Cost

Given the above list of requirements, it is less likely there exists a surrogate that meets all these requirements. Our identification and evaluation processes are described in the following sections. The requirement 4 is briefly addressed. The requirements 5 and 6 have not been considered for simplicity and budget considerations.

\subsection{Summary of Past Melter Data}

A summary of past melter testing data is presented in this section to establish the state of knowledge in this area as well as to determine the technical scope of the present task. Three major melter test campaigns testing noble metals have been completed in the past: 1) PNNL test, 2) German melter test, and 3) Integrated DWPF (Defense Waste Processing Facility) Melter System (IDMS). Noble metals have been included in glass development studies since some of the earliest waste solidification and vitrification work at PNNL (Sundaram and Perez, 2000). The insolubility of noble metals in glasses was observed at those early stages and was also known from the literature; however, the effect this insolubility could have on melter operation was not known. Early works in 1970s included crucible and laboratoryscale tests. Since then, five major studies, gradient furnace testing (GFT), research scale melter (RSM) testing, engineering scale melter (ESM) testing, modeling, and engineering analysis, were completed at PNNL. German melter tests (1980s and 1990s) showed that the accumulation of noble metals could be greatly decreased by increasing the slope of the melter floor. When using a flat-bottom melter with a bottom drain, approximately 65 percent of the noble metals fed were retained in the melter. However, with a $75^{\circ} / 60^{\circ}$ sloped melter floor, net deposits of noble metals were not detected by measuring changes in electrical resistance at the end of each pour through the bottom drain. After comparing two systems for glass pouring, the bottom drain was found to be more efficient than the overflow system in discharging noble metals. For $\mathrm{Ru}$, retention was 10.3 percent using the bottom drain and 41.4 percent with the overflow system. Air sparging was also tested to determine its effects on noble metals accumulation. With a melter having $45^{\circ}$-sloped floor, agitating the molten glass resulted in a decrease of Ru retention from 38 percent to 24 percent, and a decrease of Pd retention from 45 percent to 3 percent. However, in tests with a $75^{\circ} / 60^{\circ}$ sloped floor, it was found that air sparging was not effective enough at suspending noble metal particles to allow discharge through the overflow system. A thorough investigation of the behavior of noble metal deposits and a complete analysis of the individual particles was also performed. It was concluded that the removal of Rh from the simulant waste stream had no effect on the size and sedimentation of other noble metals. 
The IDMS was designed as a pilot-scale test facility for the DWPF. Before testing with the IDMS, two short-term noble metals campaigns with a 1/100th scale mini-melter revealed a need for extended noble metals testing. Numerous test runs with the IDMS melter addressed the designs of the DWPF feed preparation system, offgas system, and the melter itself. The IDMS engineering-scale melter is prototypic of the DWPF melter. It was designed with a melt surface area of $0.29 \mathrm{~m}^{2}$ (approximately 1/9th of the DWPF surface area), and a melt volume of $0.20 \mathrm{~m}^{3}$. The IDMS has conducted a total of 16 noble metalrelated runs with four different types of wastes sludges (Blend, HM, PUREX, and NCAW) containing various amounts of noble metals. Some of the sludge compositions were modified in order to judge the effects of components such as mercury and nitrite (Hutson et al. 1991; Hutson 1992; Hutson 1993).

Table 2.2 summarizes the noble metals found in various melter runs. The summary clearly indicates that the most commonly found species is $\mathrm{RuO}_{2}$ in the melter. $\mathrm{Ru}$ has always been found in association with $\mathrm{RuO}_{2}$ and other noble metals. Therefore, $\mathrm{Ru}-\mathrm{RuO}_{2}$ system was studied for surrogate evaluation and testing.

\subsection{Density}

As the settling is a physical phenomenon, density criterion is first considered. In order to closely simulate and study the suspension and settling characteristics, the surrogate must have density values comparable to that of the noble metal or oxide. The density of $\mathrm{RuO}_{2}$ is $6.97 \mathrm{~g} / \mathrm{cm}^{3}$ and $\mathrm{Ru}, 12.30 \mathrm{~g} / \mathrm{cm}^{3}$.

The down-selection was done in two or three steps. First the elements and compounds with density values within $\pm 10 \%$ of the density values of $\mathrm{Ru}$ and $\mathrm{RuO}_{2}$ were listed. The candidates were evaluated for hazards and stability. The next stage was to narrow the range down to $\pm 5 \%$ and the evaluation was repeated. In the case of $\mathrm{Ru}$, third stage narrowed the range down to $\pm 3 \%$. The results are summarized in Tables $2.3\left(\mathrm{RuO}_{2}\right)$ and 2.4 for $\mathrm{Ru} . \mathrm{WO}_{3}\left(7.20 \mathrm{~g} / \mathrm{cm}^{3}\right)$ and $\mathrm{WO}_{2}\left(12.11 \mathrm{~g} / \mathrm{cm}^{3}\right)$ were selected as surrogates for $\mathrm{RuO}_{2}$ and $\mathrm{Ru}$, respectively. 


\section{Table 2-1 Properties of Noble Metals}

\begin{tabular}{|c|c|c|c|c|c|c|c|c|c|}
\hline Property & Iron & Cobalt & Nickel & Ruthenium & Rhodium & Palladium & Osmium & Iridium & Platinum \\
\hline Atomic Weight & 55.845 & 58.9332 & 58.6934 & 101.07 & 102.9055 & 106.42 & 190.23 & 192.217 & 195.087 \\
\hline $\mathrm{mp}\left({ }^{\circ} \mathrm{C}\right)$ & 1538 & 1495 & 1455 & 2334 & 1964 & 1554.9 & 3033 & 2446 & 1768.4 \\
\hline $\mathrm{bp}\left({ }^{\circ} \mathrm{C}\right)$ & 2861 & 2927 & 2913 & 4150 & 3695 & 2963 & 5012 & 4428 & 3825 \\
\hline Density $\left(\mathrm{g} / \mathrm{cm}^{3}\right)$ & 7.87 & 8.86 & 8.9 & 12.1 & 12.4 & 12 & 22.59 & 22.5 & 21.5 \\
\hline Density $\left(\mathrm{g} / \mathrm{cm}^{3}\right) @ \mathrm{mp}$ & 6.98 & 7.75 & 7.81 & 10.65 & 10.7 & 10.38 & 20 & 19 & 19.77 \\
\hline Heat Capacity $(\mathrm{J} / \mathrm{g} \mathrm{K}) @ 25^{\circ} \mathrm{C}$ & 0.449 & 0.421 & 0.444 & 0.328 & 0.243 & 0.246 & 0.13 & 0.131 & 0.133 \\
\hline Thermal Conductivity (cal $/ \mathrm{s} . \mathrm{cm} .{ }^{\circ} \mathrm{C}$ ) & 0.19 & 0.1653 & 0.198 & & 0.36 & & & & \\
\hline Spec. Heat (J/g K) & 0.449 & 0.421 & 0.444 & 0.238 & 0.243 & 0.246 & 0.13 & 0.131 & 0.133 \\
\hline Enthalpy of Fusion $(\mathrm{kJ} / \mathrm{mol})$ & 13.81 & 16.2 & 17.48 & 38.59 & 26.59 & 16.74 & 57.85 & 41.12 & 22.17 \\
\hline Heat of Vaporization (kcal/g-atom) & 84.6 & 1500 & 91 & 148 & 127 & 90 & 162 & 152 & 122 \\
\hline Electrical Resistivity $\left(10^{-8} \Omega\right) @, 273 \mathrm{~K}$ & 8.57 & 5.6 & 6.16 & 7.1 & 4.3 & 9.78 & 8.1 & 4.7 & 9.6 \\
\hline Electronegativity (Paulings) & 1.83 & 1.88 & 1.91 & 2.2 & 2.28 & 2.2 & 2.2 & 2.2 & 2.2 \\
\hline Covalent Radius (Angstroms) & 1.17 & 1.16 & 1.15 & 1.25 & 1.25 & 1.28 & 1.26 & 1.27 & 1.3 \\
\hline Linear Coefficient of Expansion $\left(\mathrm{k}^{-1}\right)$ & $11.8 \times 10^{-6}$ & $13.0 \times 10^{-6}$ & $13.4 \times 10^{-6}$ & $6.4 \times 10^{-6}$ & $8.2 \times 10^{-6}$ & $11.8 \times 10^{-6}$ & $5.1 \times 10^{-6}$ & $6.4 \times 10^{-6}$ & $8.8 \times 10^{-6}$ \\
\hline Electrical Resistivity (u $\Omega-\mathrm{cm})$ & 9.71 & 6.34 & 6.844 & 7.2 & 4.5 & 9.93 & 8.12 & 5.11 & 9.85 \\
\hline Crystal Structure & cubic, bc & hexagonal & cubic, fc & hexagonal & cubic, fc & cubic, fc & hexagonal & cubic, fc & cubic, fc \\
\hline
\end{tabular}

CRC Handbook, 81st Edition

Alfa Aesar: Research Chemicals, Metals and Materials......1997-98 
Table 2-2. Summary of Melter Tests

\begin{tabular}{|c|c|c|c|c|c|c|}
\hline \multirow[t]{2}{*}{$\begin{array}{l}\text { Metal or } \\
\text { Compound }\end{array}$} & \multicolumn{2}{|c|}{$\begin{array}{c}\text { PNNL Findings } \\
\text { (1) }\end{array}$} & \multicolumn{2}{|c|}{$\begin{array}{c}\text { German Findings } \\
(2)\end{array}$} & \multicolumn{2}{|c|}{$\begin{array}{c}\text { IDMS Findings } \\
\text { (3) }\end{array}$} \\
\hline & $\underline{\text { Particle Size }}$ & Composition & $\underline{\text { Particle Size }}$ & Composition & Particle Size & Composition \\
\hline $\mathbf{R u}$ & $\begin{array}{l}\text { Submicron, } \\
\text { spheres }\end{array}$ & $\begin{array}{l}30-70 \% \text { retention, } \\
\text { present as } \mathrm{RuO}_{2}\end{array}$ & $\begin{array}{l}2.0 \text { - } 5.0 \text { micron } \\
\text { spheres }\end{array}$ & $11 \mathrm{wt} \%$ & & $\begin{array}{c}\text { Between } 0.16-7.74 \\
\text { wt. } \% \text {, present as }\end{array}$ \\
\hline $\mathbf{R h}$ & $\begin{array}{l}<10 \text { micron, } \\
\text { spheres }\end{array}$ & 1 to 2 microns & $\begin{array}{l}1.5-2.0 \text { micron } \\
\text { spheres }\end{array}$ & $6 \mathrm{wt} \%$ & & $\begin{array}{c}\text { Between } 0.026-1.21 \\
\text { wt } \%\end{array}$ \\
\hline $\mathbf{P d}$ & $\begin{array}{l}\text { Submicron to } 10 \\
\text { micron, spheres }\end{array}$ & $1.0 \mathrm{wt} \%$ & $\begin{array}{l}1.5-2.0 \text { micron } \\
\text { spheres }\end{array}$ & $5 \mathrm{wt} \%$ & & $\begin{array}{c}\text { Between } 0.031-0.17 \\
\text { wt } \%\end{array}$ \\
\hline $\mathrm{RuO}_{2}$ & $\begin{array}{l}<10 \text { micron } \\
\text { needles }\end{array}$ & 1.4 wt $\%$ & $\begin{array}{c}2.0 \text { - } 5.0 \text { micron, } \\
\text { needles }\end{array}$ & $0.05-0.1 \mathrm{wt} \%$ & & $\begin{array}{c}\text { Between } 0.16-7.74 \\
\text { wt } \%\end{array}$ \\
\hline Spinels & $\begin{array}{l}2 \text { to } 4 \text { micron, } \\
\text { cubic }\end{array}$ & & & & & $\begin{array}{r}\text { Between } 27-66 \\
\text { wt. } \%, \text { Cr-rich } \\
\end{array}$ \\
\hline
\end{tabular}

(1) - Vitrification studies conducted at PNL (Jensen et al. 1983) from "Preliminary Melter Performance Assessment Report", PNL-9822/UC-721.

(2) - From "Virtification of Noble Metals Containing NCAW Simulant with an Engineering Scale Melter (ESM)" (W. Grunwald et al. 1993).

(3) - From "Inspection and Analysis of the Integrated DWPF Melter System (IDMS) After Seven Years of Continuous Operation",

WSRC-MS-99-0036 (C.M. Jantzen and D. Lambert, 1994). 
Table 2-3. Potential Surrogates For $\mathrm{RuO}_{2}$ Based On Density $\left(6.97 \mathrm{~g} / \mathrm{cm}^{3} \pm 10 \%\right)$

\begin{tabular}{|c|c|}
\hline Metal or Compound & Density $\left(\mathrm{g} / \mathrm{cm}^{3}\right)$ \\
\hline Americium (III) Bromide & 6.85 \\
\hline Americium (IV) Fluoride & 7.23 \\
\hline Antimony & 6.68 \\
\hline Antimony (III, V) Oxide & 6.64 \\
\hline Arsenic (III) Telluride & 6.50 \\
\hline Barium Stannate & 7.24 \\
\hline Bismuth Basic Carbonate & 6.86 \\
\hline Bismuth Oxychloride & 7.72 \\
\hline Bismuth Selenide & 7.50 \\
\hline Bismuth Sulfide & 6.78 \\
\hline Bismuth Telluride & 7.74 \\
\hline Cadmium Antimonide & 6.92 \\
\hline Cadmium Iodide & 6.48 \\
\hline Cadmium Titanate & 6.50 \\
\hline Cerium & 6.77 \\
\hline Cerium (III) Carbide & 6.90 \\
\hline Cerium (IV) Oxide & 7.65 \\
\hline Chromium Arsenide & 7.04 \\
\hline Chromium Carbide & 6.68 \\
\hline Chromium Nitride & 6.80 \\
\hline Chromium (III) Telluride & 7.00 \\
\hline Cobalt Arsenide $\left(\mathrm{CoAs}_{2}\right)$ & 7.20 \\
\hline Cobalt Arsenide $\left(\mathrm{CoAs}_{3}\right)$ & 6.84 \\
\hline Cobalt Boride (CoB) & 7.25 \\
\hline Cobalt (II) Selenide & 7.65 \\
\hline Copper (I) Selenide & 6.84 \\
\hline Copper (II) Telluride & 7.09 \\
\hline Copper (II) Tungstate & 7.50 \\
\hline Dysprosium Boride & 6.98 \\
\hline Dysprosium (III) Hydride & 7.10 \\
\hline Erbium Boride & 7.00 \\
\hline Erbium Silicide & 7.26 \\
\hline Erbium Telluride & 7.11 \\
\hline Europium (III) Oxide & 7.42 \\
\hline Gadolinium (III) Oxide & 7.07 \\
\hline Halfnium Fluoride & 7.10 \\
\hline Halfnium Silicide & 7.60 \\
\hline Holmium Fluoride & 7.66 \\
\hline Holmium Silicide & 7.10 \\
\hline Indium (III) Oxide & 7.18 \\
\hline Indium (III) Iodide & 7.40 \\
\hline Iron Boride $\left(\mathrm{Fe}_{2} \mathrm{~B}\right)$ & 7.30 \\
\hline Iron Boride (FeB) & 7.00 \\
\hline Iron Phosphide & 6.80 \\
\hline Iron Tungstate & 7.51 \\
\hline Lead (II) Bromide & 6.69 \\
\hline Lead (II) Carbonate & 6.60 \\
\hline Lead (II) Chloride Fluoride & 7.05 \\
\hline Lead (II) Hydroxide & 7.59 \\
\hline Lead (II) Molybdate & 6.70 \\
\hline Lead (II) Oxide Hydrate & 7.41 \\
\hline
\end{tabular}

Lead (II) Phosphate $\quad 7.01$

Lead (II) Selenite $\quad 7.00$

Lead (II) Sulfide $\quad 7.60$

Lead (IV) Fluoride $\quad 6.70$

Lutetium Boride $\quad 7.00$

Magnesium Tungstate $\quad 6.84$

Manganese $\quad 7.30$

Manganese Antimonide (MnSb) $\quad 6.90$

Manganese Antimonide ( $\left.\mathrm{Mn}_{7} \mathrm{Sb}\right) \quad 7.00$

Manganese Boride $\quad 7.20$

Manganese Carbide $\quad 6.89$

Manganese Tungstate $\quad 7.20$

Mercury (I) Chloride $\quad 7.16$

Molybdenum Phosphide $\quad 7.34$

Molybdenum (IV) Selenide $\quad 6.90$

Neodymium $\quad 7.01$

Neodymium Oxide $\quad 7.24$

Neodymium Telluride $\quad 7.00$

Nickel Bromide $\quad 7.13$

Nickel Phosphide $\quad 7.33$

Nickel Selenide $\quad 7.20$

Niobium (II) Oxide $\quad 7.30$

Praseodymium Oxide $\quad 6.90$

Praseodymium Telluride $\quad 7.00$

$\begin{array}{ll}\text { Promethium } & 7.26\end{array}$

Rhenium (IV) Fluoride $\quad 7.49$

Rhodium (IV) Oxide $\quad 7.20$

Samarium $\quad 7.52$

Samarium (III) Telluride $\quad 7.31$

Silver (I) Oxide $\quad 7.20$

Silver (I) Sulfide $\quad 7.23$

Tantalum Aluminide $\quad 7.02$

Tantalum (IV) Sulfide $\quad 6.86$

Tellurium Dichloride $\quad 6.90$

Thallium (I) Carbonate $\quad 7.11$

Thallium (I) Chloride $\quad 7.00$

Thallium (I) Iodide $\quad 7.10$

Thallium (I) Selenide $\quad 6.88$

Thorium Boride $\quad 6.99$

Thorium Sulfide $\quad 7.30$

Tin (white) $\quad 7.27$

Tin (IV) Oxide $\quad 6.85$

Tungsten (VI) Oxide $\quad \mathbf{7 . 2 0}( \pm \mathbf{5 \%})$

Ytterbium $\quad 6.90$

Zinc $\quad 7.14$

\begin{tabular}{ll} 
Zirconium Nitride & 7.09 \\
\hline
\end{tabular}

Pink - Solıhle in $\mathrm{H}_{\imath} \mathrm{O}$ or Glass Melt

Blue - Toxic

Yellow - Radioactive

Green - Non-oxide (unlikely surrogate) 
Table 2-4. Potential Surrogates For Ru Based On Density $\left(12.30 \mathrm{~g} / \mathrm{cm}^{3} \pm 10 \%\right)$

\begin{tabular}{|c|c|}
\hline Metal or Compound & Density $\left(\mathrm{g} / \mathrm{cm}^{3}\right)$ \\
\hline Halfnium & 13.31 \\
\hline Halfnium Carbide & 12.20 \\
\hline Palladium & 12.02 \\
\hline Tungsten Dioxide & $12.11( \pm 3 \%)$ \\
\hline Americium Dioxide & 11.68 \\
\hline Iridium Dioxide & 11.67 \\
\hline Lead & 11.34 \\
\hline Neptunium Dioxide & 11.11 \\
\hline Osmium Dioxide (brown) & 11.37 \\
\hline Plutonium Dioxide & 11.46 \\
\hline Rhenium Dioxide & 11.40 \\
\hline Rhodium & 12.40 \\
\hline Tantallum Diboride & 11.15 \\
\hline Thallium & 11.85 \\
\hline Thorium & 11.70 \\
\hline Uranium Diboride & 12.70 \\
\hline Uranium Dicarbide & 11.28 \\
\hline Uranium Hydride & 10.95 \\
\hline Uranium Dioxide & 10.96 \\
\hline $\begin{array}{l}\text { Red - Soluble in } \mathrm{H}_{2} \mathrm{O} \text { or Glass Melt } \\
\text { Blue - Toxic } \\
\text { Yellow - Radioactive } \\
\text { Green - Non-oxide (unlikely surrogate) }\end{array}$ & \\
\hline
\end{tabular}

\subsection{Thermodynamic Stability}

The thermodynamic calculation was performed using $\mathrm{F} * \mathrm{~A} * \mathrm{C} * \mathrm{~T}^{\mathrm{a}}$. The free energy of formation of the oxides as a function of temperature is shown in Figure 2.1. $\mathrm{WO}_{2}$ and $\mathrm{WO}_{3}$ are relatively more stable than $\mathrm{RuO}_{2}$ over a temperature range of $0-1600^{\circ} \mathrm{C}$. Note that these free energy values are for ideal states at ambient pressure. With change in the melter atmosphere, the redox equilibrium will shift. W-O system shows the promise of serving as a surrogate for $\mathrm{Ru}$ as well as $\mathrm{RuO}_{2}$. As shown below, $\mathrm{WO}_{2}\left(12.11 \mathrm{~g} / \mathrm{cm}^{3}\right)$ can act as a surrogate for $\mathrm{Ru}\left(12.30 \mathrm{~g} / \mathrm{cm}^{3}\right)$ under reducing conditions. Alternatively, $\mathrm{WO}_{3}\left(7.20 \mathrm{~g} / \mathrm{cm}^{3}\right)$ can act as a surrogate for $\mathrm{RuO}_{2}\left(6.97 \mathrm{~g} / \mathrm{cm}^{3}\right)$ under oxidizing conditions.

$\begin{array}{lll}\text { Reduction } & \leftrightarrow & \text { Oxidation } \\ \mathrm{Ru}\left(12.30 \mathrm{~g} / \mathrm{cm}^{3}\right) & \leftrightarrow & \mathrm{RuO}_{2}\left(6.97 \mathrm{~g} / \mathrm{cm}^{3}\right) \\ \mathrm{WO}_{2}\left(12.11 \mathrm{~g} / \mathrm{cm}^{3}\right) & \leftrightarrow & \mathrm{WO}_{3}\left(7.20 \mathrm{~g} / \mathrm{cm}^{3}\right)\end{array}$

\footnotetext{
${ }^{\mathrm{a}} \mathrm{F} * \mathrm{~A} * \mathrm{C} * \mathrm{~T}=$ Facility for the Analysis of Chemical Thermodynamics, Ecole Polytechnique, Universit] of Montr] al, Canada.
} 


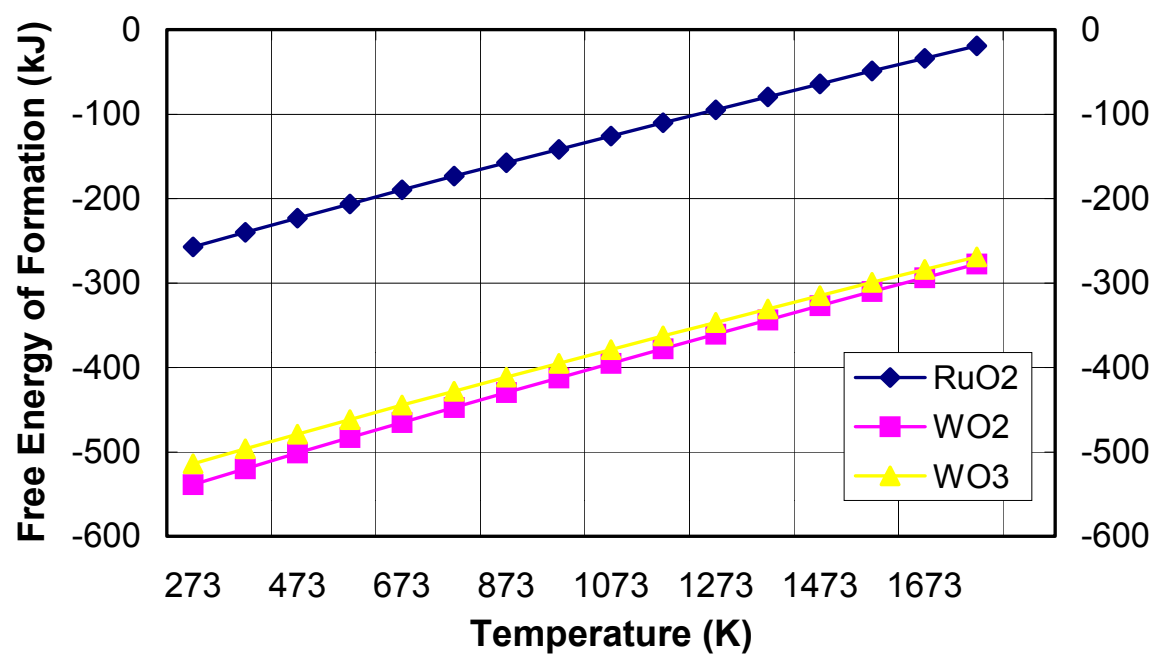

Figure 2-1. Thermodynamic Stability

\subsection{Solubility}

Ruthenium $(\mathrm{Ru})$ and other platinum group of metals are sparingly soluble in glass-forming melts. However, measurable amounts of chemically dissolved $\mathrm{Ru}$ (about 100-2000 ppm) have been reported to dissolve in soda-silica glass melts (Mukerji and Biswas, 1967). The solubility appears to be enhanced with rising temperatures and higher $\mathrm{Na}_{2} \mathrm{O} / \mathrm{SiO}_{2}$ compositional ratios. The solubility of ruthenium in phosphate glasses approaches $10000 \mathrm{ppm}$ of $\mathrm{Ru}$ at $1000^{\circ} \mathrm{C}$ (Biswas and Mukerji, 1968). In these melts, the process by which $\mathrm{Ru}$ as $\mathrm{RuO}_{2}$ goes into the melt solution has been first linked to the indirect reaction of the $\mathrm{RuO}_{2}$ with singly bonded oxygens of the melt network.

The solubility of $\mathrm{Ru}$ has been then linked to the stabilization of certain oxidation states of $\mathrm{Ru}$ (redox chemistry) in simple glasses. Ru displays ten oxidation states in its compounds and complexes (Bailar et al., 1973). Every positive oxidation state to +8 is known as the neutral and -2 states.

Absorption spectra of glasses colored by $\mathrm{Ru}$ indicate the presence of $\mathrm{Ru}(\mathrm{III})$ and $\mathrm{Ru}(\mathrm{IV})$ dissolved in acidic silicate glasses, $\mathrm{Ru}(\mathrm{IV})$ and $\mathrm{Ru}(\mathrm{VI})$ in basic silicate glasses, $\mathrm{Ru}(\mathrm{VI})$ and $\mathrm{Ru}(\mathrm{VII})$ in soda phosphate glasses, $\mathrm{Ru}(\mathrm{VI})$ and $\mathrm{Ru}(\mathrm{VI})$ in lead phosphate glasses as well as borophosphate glasses and $\mathrm{Ru}(\mathrm{III})$ and $\mathrm{Ru}(\mathrm{IV}$ ) in borosilicate glasses (Mukerji and Biswas, 1971; Mukerji, 1972). The colors of these glasses range from pink to yellow to green depending on the composition and synthesis conditions owing to the various $\mathrm{Ru}$ oxidation states. Electron spin resonance (ESR) data indicate the absence of $\mathrm{Ru}(\mathrm{V})$ and the presence of $\mathrm{Ru}(\mathrm{III})$ and $\mathrm{Ru}(\mathrm{IV})$ in borosilicates manufactured at $1500^{\circ} \mathrm{C}$ (Mukerji, 1975). High $\mathrm{Ru}$ solubilities always correspond to the occurrence of $\mathrm{Ru}(\mathrm{VI})$ in the glasses, indicating that $\mathrm{Ru}(\mathrm{VI})$ is the species most easily accommodated within the glass melt structure. Schreiber and coworkers (Schreiber et al., 1986) have investigated the amount of Ru dissolved in a borosilcate glass system as a function of amount of $\mathrm{Ru}$, redox additives, time, and melt temperature and atmosphere. In all the cases, the Ru solubility has been less than about $0.001 \mathrm{wt} . \%$, the approximate limit of detection in the glasses. Insoluble $\mathrm{RuO}_{2}$ has always been found in these glasses. These results have not substantiated the results by Muherji and Biswas ((Mukerji and Biswas, 1967; Biswas and Mukerji, 1968; Mukerji and Biswas, 1971; Mukerji, 1972; Mukerji, 1975).

Generally solubility is studied by dissolving the dopant in a glass melt characterizing the glass post mortem. Two somewhat different techniques used to obtain solubility of species in glass melts are: 1) the stirred crucible method (Dingwell et al., 1994) and 2) the wire loop method (Holzheid et al., 1994; 
Borisov et al., 1994). The principal advantage of the stirred crucible technique is that changes in oxygen fugacity $\left(f \mathrm{O}_{2}\right)$ and temperature (or composition) can be performed in a stepwise fashion without interruption of the experiment, and the response of the samples can be monitored by taking samples at any time. This can be used to demonstrate the achievement of equilibrium by time series and by reversals both in temperature and in $\mathrm{fO}_{2}$. However, the relatively long times needed to achieve equilibrium with this method makes its use undesirable at higher temperatures $\left(>1500^{\circ} \mathrm{C}\right)$, where the time spent at temperature needs to be as short as possible to minimize the inevitable deterioration of the gas-mixing furnace under extreme conditions. Therefore, the conventional wire-loop technique is used at 1600 and $1700^{\circ} \mathrm{C}$. Ertel and coworkers (Ertel et al., 1996) have determined the solubility of tungsten (W) in a haplobasaltic melt as a function of $f \mathrm{O}_{2}$ in the temperature range of $1300-1700^{\circ} \mathrm{C}$, using the above the two techniques. According to this work, $\mathrm{W}$ dissolves in the melt with a quadrivalent (4+) formal oxidation state over the entire range of $\mathrm{O}_{2}$ and temperature investigated. The solubility of $\mathrm{W}$ decreases strongly with increasing temperature at constant $f \mathrm{O}_{2}$. W concentrations range form $20 \mathrm{ppm}$ to $17 \mathrm{wt} \%$. The solution of $\mathrm{WO}_{2}$ in the melt may be described by Henry's Law (shown in Figure 2.2) up to remarkably high temperatures (e.g., $14 \mathrm{wt} \%$ at $1500^{\circ} \mathrm{C}$ ). In the Figure 2.2, the hatched area shows the range in which the Henry's Limit is obeyed.

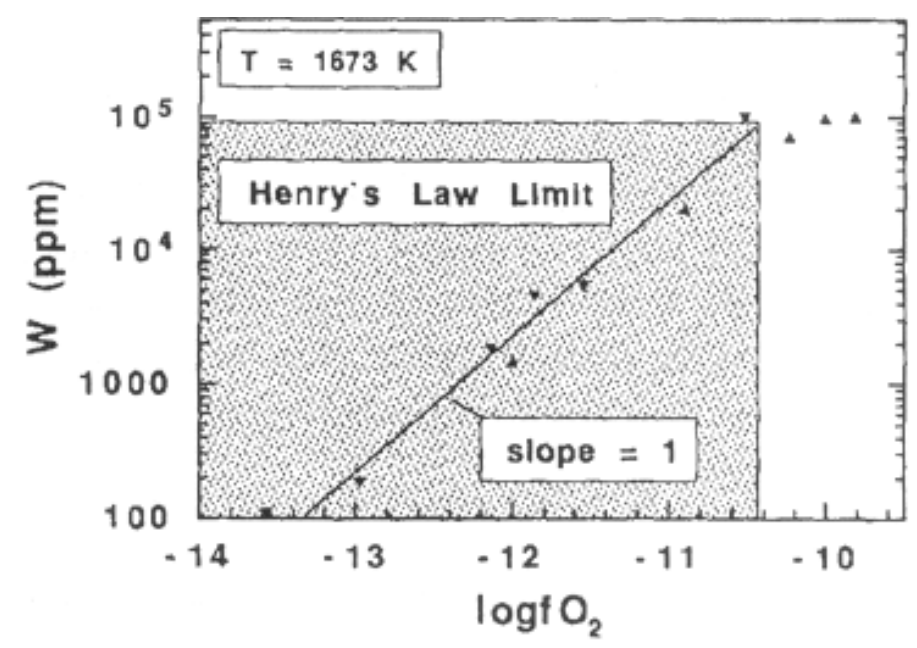

Figure 2-2. The Henry's Law Limit for $W$ in Silicate Melt at $1400^{\circ} \mathrm{C}$ (Ertel et al., 1996)

As the present task's main goal is to identify suitable surrogate for noble metals, the exact solubility of noble metals has not been determined. A systematic study of the Ru solubility in high-level waste glass compositions is needed to understand its precise role in processing HLW glass compositions.

\subsection{Partitioning}

Spinel phases are consistently found to be concentrators of platinum group of elements (PGE) in geochemistry. Capobianco and Drake have studied the partitioning of PGE between spinel and silicate melt. The experimental details are given elsewhere (Capobianco and Drake, 1990). The silicate melt is from the $\mathrm{CaO}-\mathrm{Al}_{2} \mathrm{O}_{3}-\mathrm{MgO}-\mathrm{SiO}_{2}$ system. The bulk glass melt composition is temperature dependent because of the spinel capsule dissolves into the sample at higher temperature. The starting capsule material is a very non-stoichiometric spinel (approximately $90 \mathrm{wt} \% \mathrm{Al}_{2} \mathrm{O}_{3}, 10 \mathrm{wt} \% \mathrm{MgO}$ ), which at testing conditions exsolves into corundum and a spinel with less excess $\mathrm{Al}_{2} \mathrm{O}_{3}$. Table 2.5 summarizes experimentally determined spinel/melt partition coefficients for $\mathrm{Pd}, \mathrm{Ru}$, and $\mathrm{Rh}$, the PGE contents of phases of interest, and experimental run conditions. 
Table 2-5. Summary of Platinum-Group Element Spinel/Melt Partition Coefficients, Run Conditions, and Phase Concentrations (in ppm)

\begin{tabular}{lccccc}
\hline & $\mathbf{D}^{\mathbf{x} / \mathbf{m e l t}}$ & $\mathbf{T}\left({ }^{\mathbf{0}} \mathbf{C}\right)$ & Spinel & Glass & Atmosphere \\
\hline Ru & $25(9)^{1}$ & 1450 & $7900(300)^{2}$ & $320(120)^{2}$ & Air \\
& $22(9)^{1}$ & 1290 & $5900(400)^{2}$ & $270(110)^{2}$ & Air \\
\hline Rh & $78(15)^{1}$ & 1450 & $4300(460)^{2}$ & $55(9)^{3}$ & Air \\
& $90(10)^{4}$ & 1300 & $50^{*}-73700 \dagger$ & $50^{*}-980 \dagger$ & Oxygen \\
\hline Pd & $<0.02$ & 1450 & $25^{*}$ & $1120(100)$ & Oxygen \\
\hline
\end{tabular}

${ }^{1}$ error in phase concentrations propagated through to quotient, D;

${ }^{2}$ standard deviation of electron probe analyses; ${ }^{3}$ single PIXE analysis and associated counting statistical error; ${ }^{4}$ standard deviation of D's calculated from analyses of immediately adjacent phases; *electron probe detection limit; trange of concentrations within single run

In the case of these melts, $\mathrm{RuO}_{2}$ is present in the $1300^{\circ} \mathrm{C}$ runs, while at $1450^{\circ} \mathrm{C}$ only $\mathrm{Ru}$ has been found in the run products. The amount of $\mathrm{Ru}$ in the spinel is not sensitive to temperature and is fairly uniform in the unattached euhedral spinels. The partition coefficients of $\mathrm{D}^{\mathrm{Ru}}$ values of $22-25 \pm 9$ indicate that $\mathrm{Ru}$ is significantly compatible in spinel in these melts.

The results of a preliminary study of partition of $\mathrm{Ru}$ and $\mathrm{W}$ in contact with spinel and a model glass are summarized in this report. Further study of partition of Ru in high-level waste glass compositions is needed.

\subsection{Cost and Availability}

The $\mathrm{RuO}_{2}$ and surrogate $\mathrm{WO}_{3}$ were purchased from Johnson Matthey and Alfa Aesar, respectively. The costs are compared in Table 2.5. $\mathrm{RuO}_{2}$ cost 25-30 times more than $\mathrm{WO}_{3}$. For the quantities ordered (100-500 grams), availability was not a problem. Large amounts of $\mathrm{RuO}_{2}$ could face supply problem.

\subsection{Surrogates Selection}

Thermodynamic and cost considerations clearly favor $\mathrm{WO}_{3}{ }^{\mathrm{b}}$ as a potential surrogate for $\mathrm{RuO}_{2}{ }^{\mathrm{c}}$. In addition, $\mathrm{Cr}_{2} \mathrm{O}_{3}, \mathrm{NiCr}_{2} \mathrm{O}_{4}$, and Inconel 600 have also been considered ${ }^{\mathrm{d}}$. Sources of $\mathrm{Cr}_{2} \mathrm{O}_{3}{ }^{\mathrm{e}}$ in melter environments are refractories and oxidation by-products of the electrode used (Inconel 690). $\mathrm{NiCr}_{2} \mathrm{O}_{4}{ }^{\mathrm{f}}$ is a basic spinel compound that has been identified in many melters and laboratory studies. Inconel $600^{\mathrm{g}}$ has chemical similarity to the electrode used in melters, Inconel 690.

\footnotetext{
${ }^{\mathrm{b}}$ Alfa Aesar

c Johnson Matthey

${ }^{\mathrm{d}}$ Personal communication with Mr. Denny Bickford at SRTC

${ }^{\mathrm{e}}$ Fisher Scientific

${ }^{\mathrm{f}}$ Alfa Aesar

${ }^{\mathrm{g}}$ GNK Sinter Metals, 22501 Gohlmann Parkway, Richton Park, IL 60471
} 
Table 2-6. Cost of $\mathrm{RuO}_{2}$ and $\mathrm{WO}_{3}$

\begin{tabular}{lll}
\multicolumn{2}{l}{ Chemical Name: } & Ruthenium oxide \\
Formula: & RuO $_{2}$ & \\
& Description & Typical Purity(\%) \\
& -100 mesh & 99.9 \\
Pricing: & Quantity (g) & Price (U.S. \$) \\
& 2 & 50.00 \\
& 10 & 166.00 \\
Chemical Name: & 50 & 768.00 \\
Formula: & WO & Tungsten oxide \\
& Description & Typical Purity (\%) \\
& $3-12$ mm pieces & 99.99 \\
& (sintered, yellow-green) & $($ vac. dep. grade) \\
& Quantity (g) & Price (U.S. \$) \\
& 50 & 50.00 \\
Pricing: & 200 & 130.00 \\
& 500 & 246.00 \\
& &
\end{tabular}




\subsection{Surrogate Characterization and Testing}

\subsection{Characterization of Surrogate Powders}

As-received powders were characterized using particle size analyzer, scanning electron microscopy (SEM), and energy dispersive spectrometry (EDS). No attempt was made to grind these materials down to specific particle size range or distribution due to preliminary nature of this investigation. These results are discussed in this section.

\subsection{1 $\mathrm{RuO}_{2}$}

$\mathrm{RuO}_{2}$ shows a narrow particle size range of about 100-400 $\mu \mathrm{m}$ with a peak around $275 \mu \mathrm{m}$. The spongy particulates show uniform distribution and some segregation.
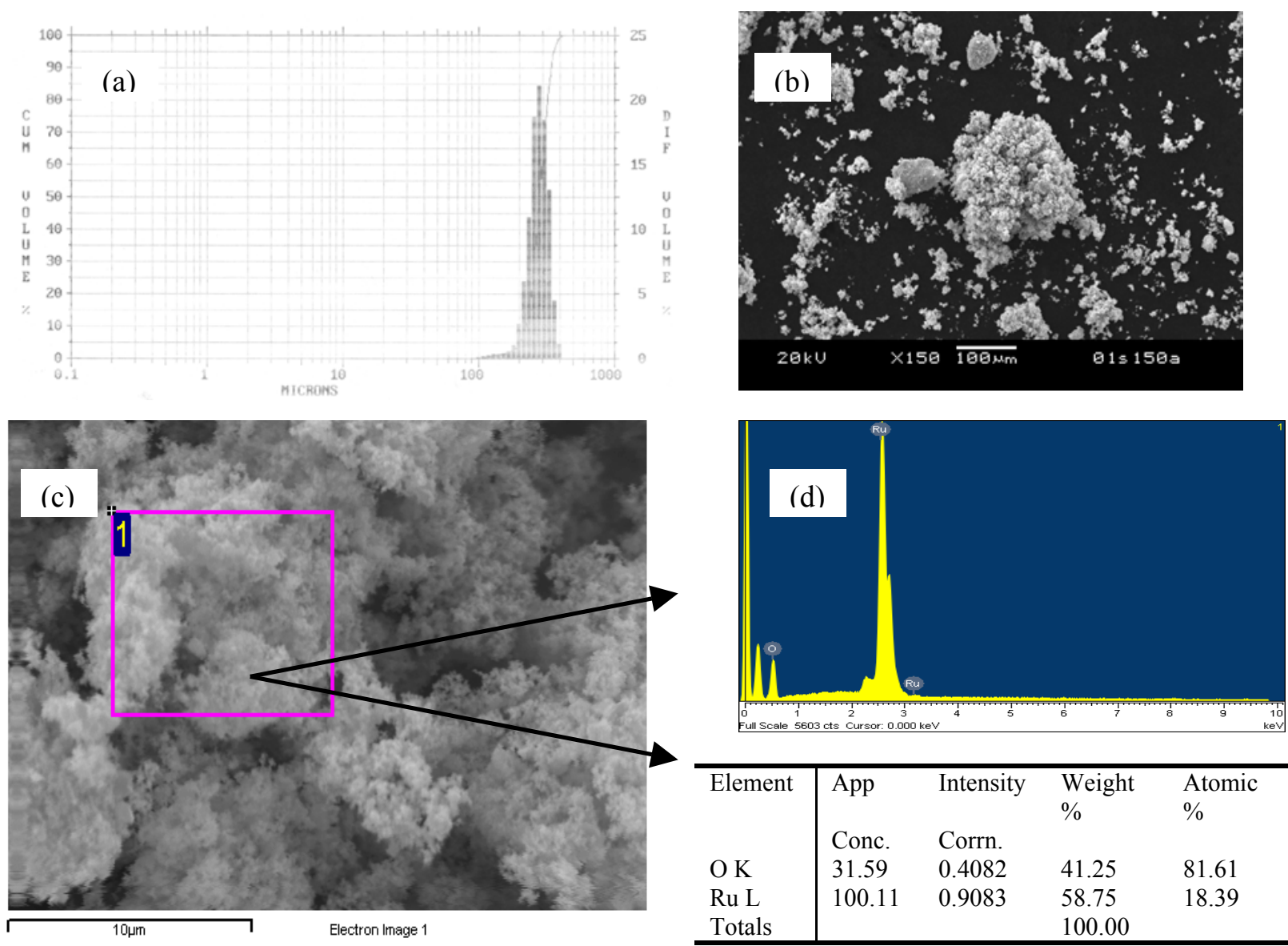

Figure 3-1. a) Particle Size, b) SEM, c) Point EDS area, and d) EDS Data of $\mathrm{RuO}_{2}$ Powder 


\subsection{2 $\mathrm{WO}_{3}$}

$\mathrm{WO}_{3}$ shows a wide particle size range of about 10-500 $\mu \mathrm{m}$ with three peaks around 20,60 , and $300 \mu \mathrm{m}$. The particulates have finer granular texture.
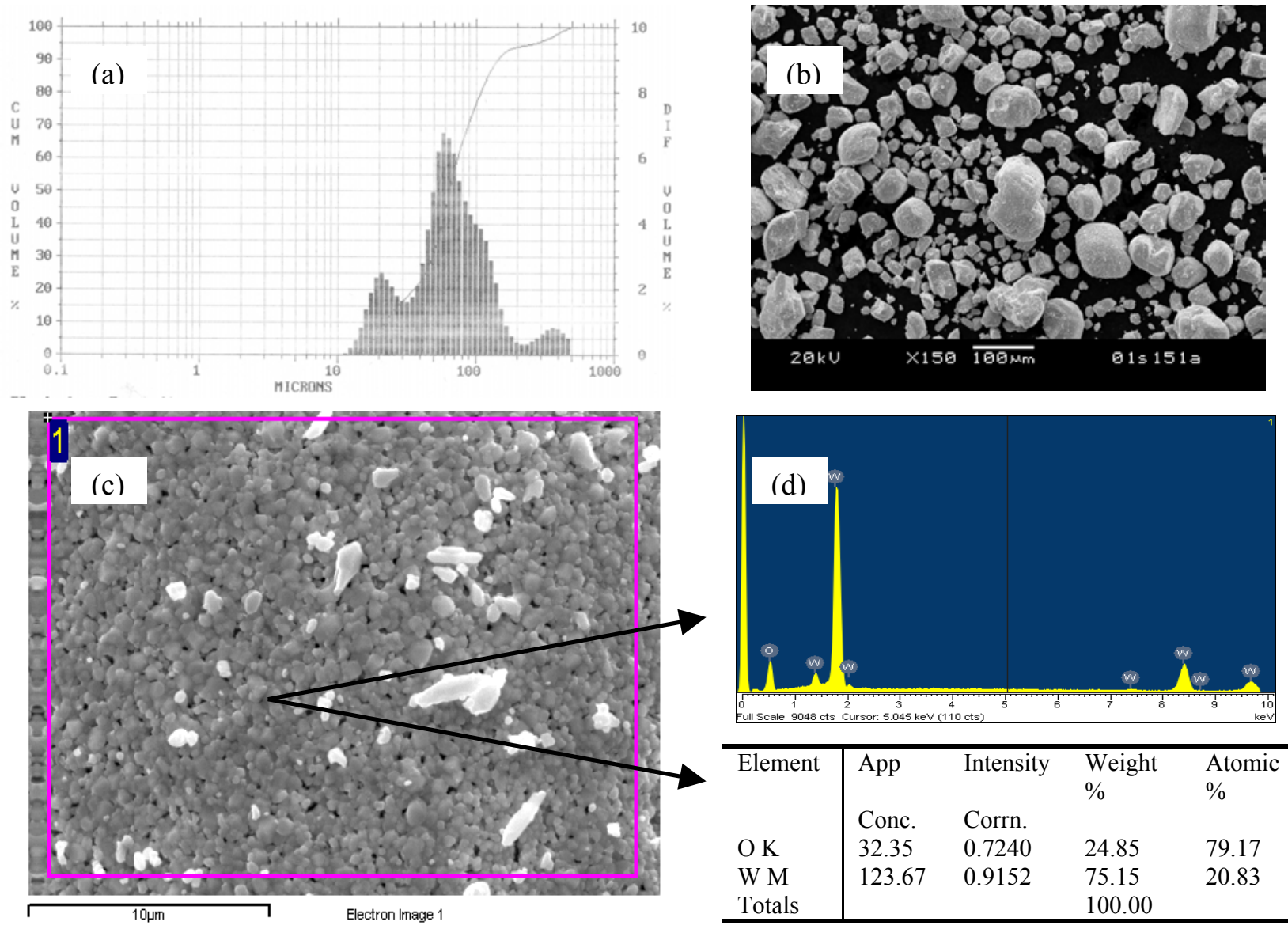

\begin{tabular}{l|llll}
\hline Element & App & Intensity & $\begin{array}{l}\text { Weight } \\
\%\end{array}$ & $\begin{array}{l}\text { Atomic } \\
\%\end{array}$ \\
& Conc. & Corrn. & & \\
O K & 32.35 & 0.7240 & 24.85 & 79.17 \\
W M & 123.67 & 0.9152 & 75.15 & 20.83 \\
Totals & & & 100.00 & \\
\hline
\end{tabular}

Figure 3-2. a) Particle Size, b) SEM, c) Point EDS area, and d) EDS Data of $\mathrm{WO}_{3}$ Powder 


\subsection{3 $\mathrm{Cr}_{2} \mathrm{O}_{3}$}

$\mathrm{Cr}_{2} \mathrm{O}_{3}$ shows a particle size range of about $0.2-5 \mu \mathrm{m}$ with two peaks around $0.8 \mu \mathrm{m}$. The spongy particulates show some segregation.
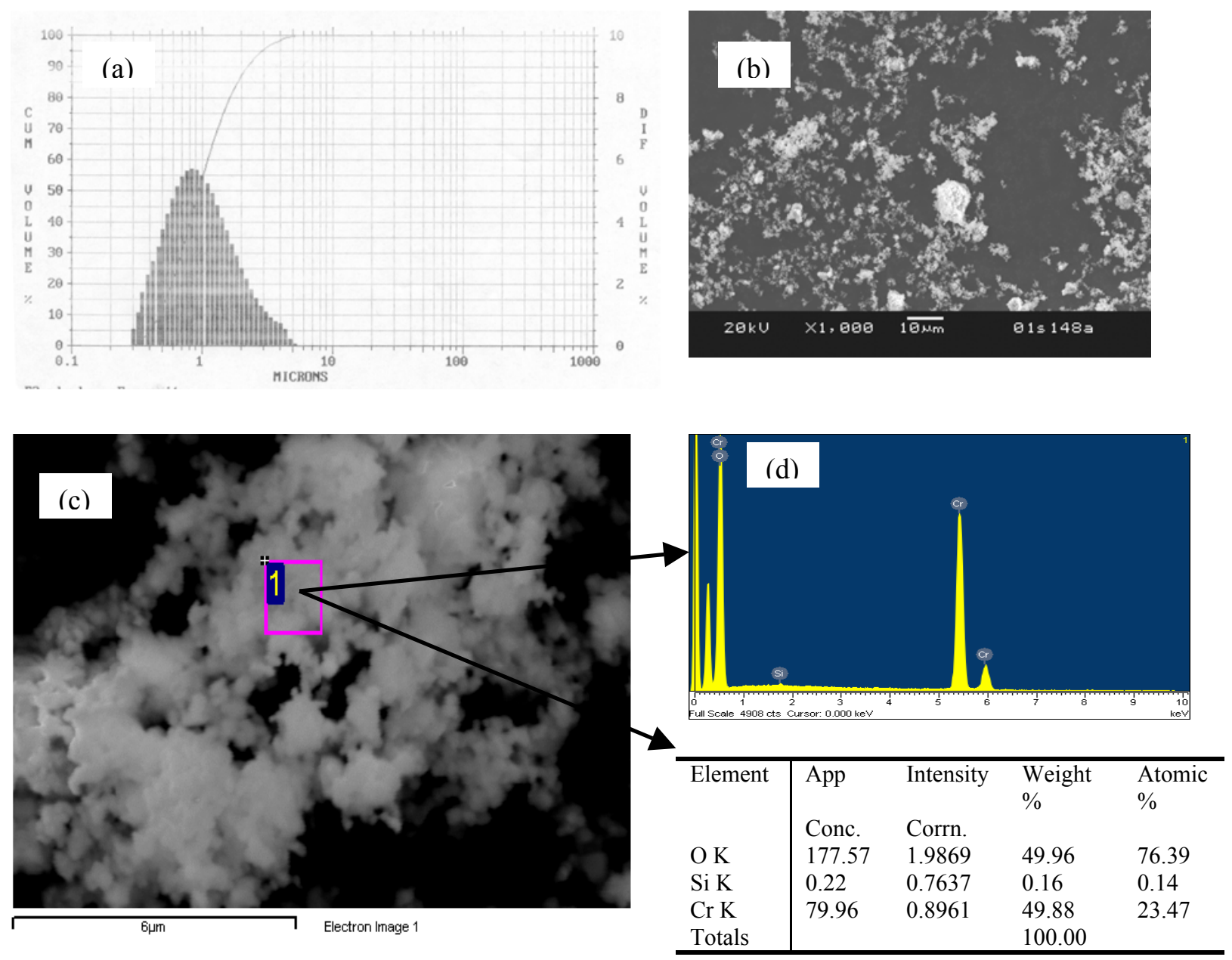

Figure 3-3. a) Particle Size, b) SEM, c) Point EDS area, and d) EDS Data of $\mathrm{Cr}_{2} \mathrm{O}_{3} \mathrm{Powder}$ 


\subsection{4 $\mathrm{NiCr}_{2} \mathrm{O}_{4}$}

$\mathrm{NiCr}_{2} \mathrm{O}_{4}$ shows the widest particle size range of about $0.25-500 \mu \mathrm{m}$ with three distinct peaks around $0.4 .5,120$, and $450 \mu \mathrm{m}$. The spongy particulates show some segregation.
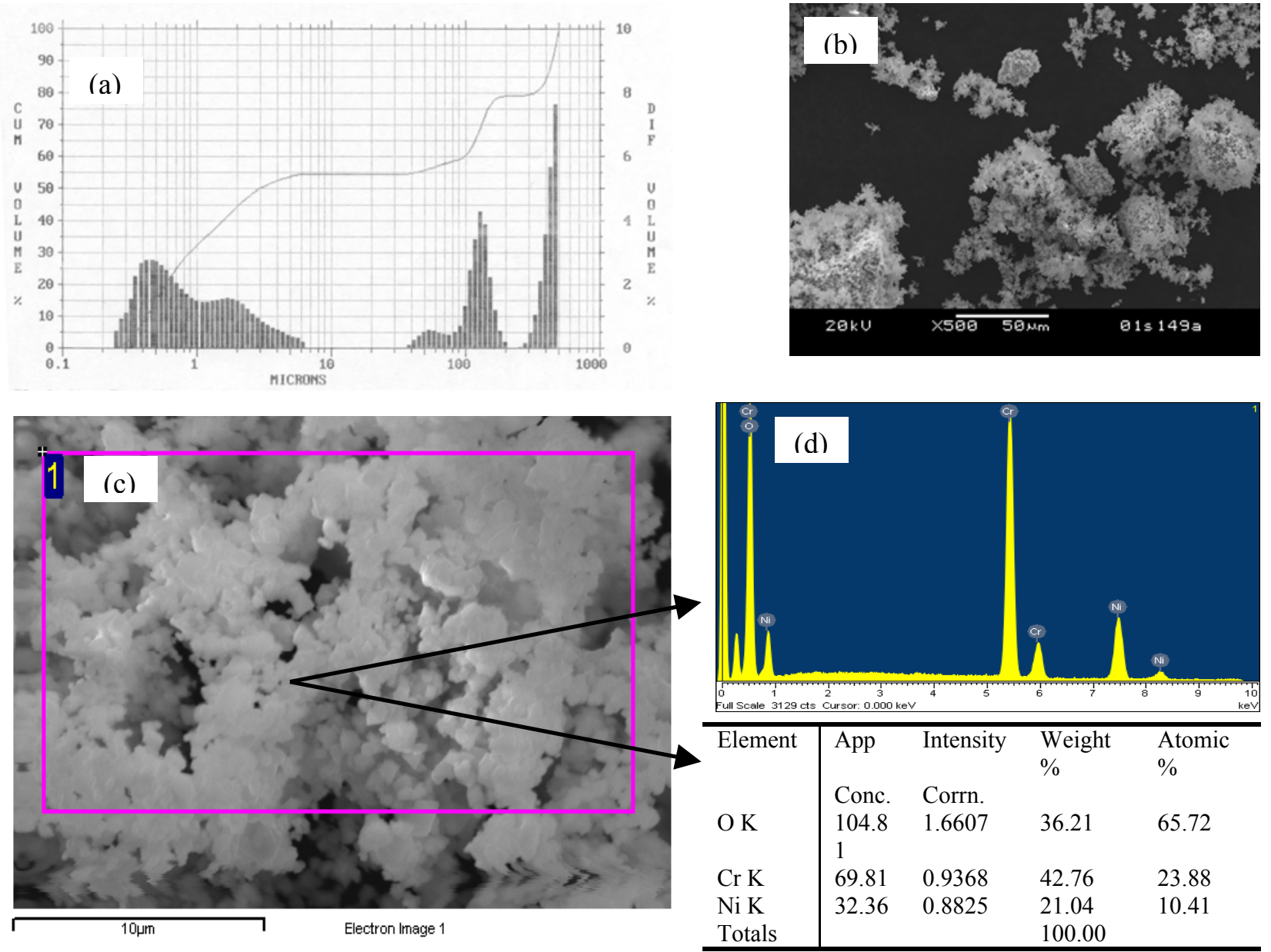

Figure 3-4. a) Particle Size, b) SEM, c) Point EDS area, and d) EDS Data of $\mathrm{NiCr}_{2} \mathrm{O}_{4} \mathrm{Powder}$ 


\subsubsection{Inconel 600}

Inconel 600 shows a sharp particle size range of about 100-500 $\mu \mathrm{m}$ with one peak around 350 $\mu \mathrm{m}$. The rounded particulates show granular texture.
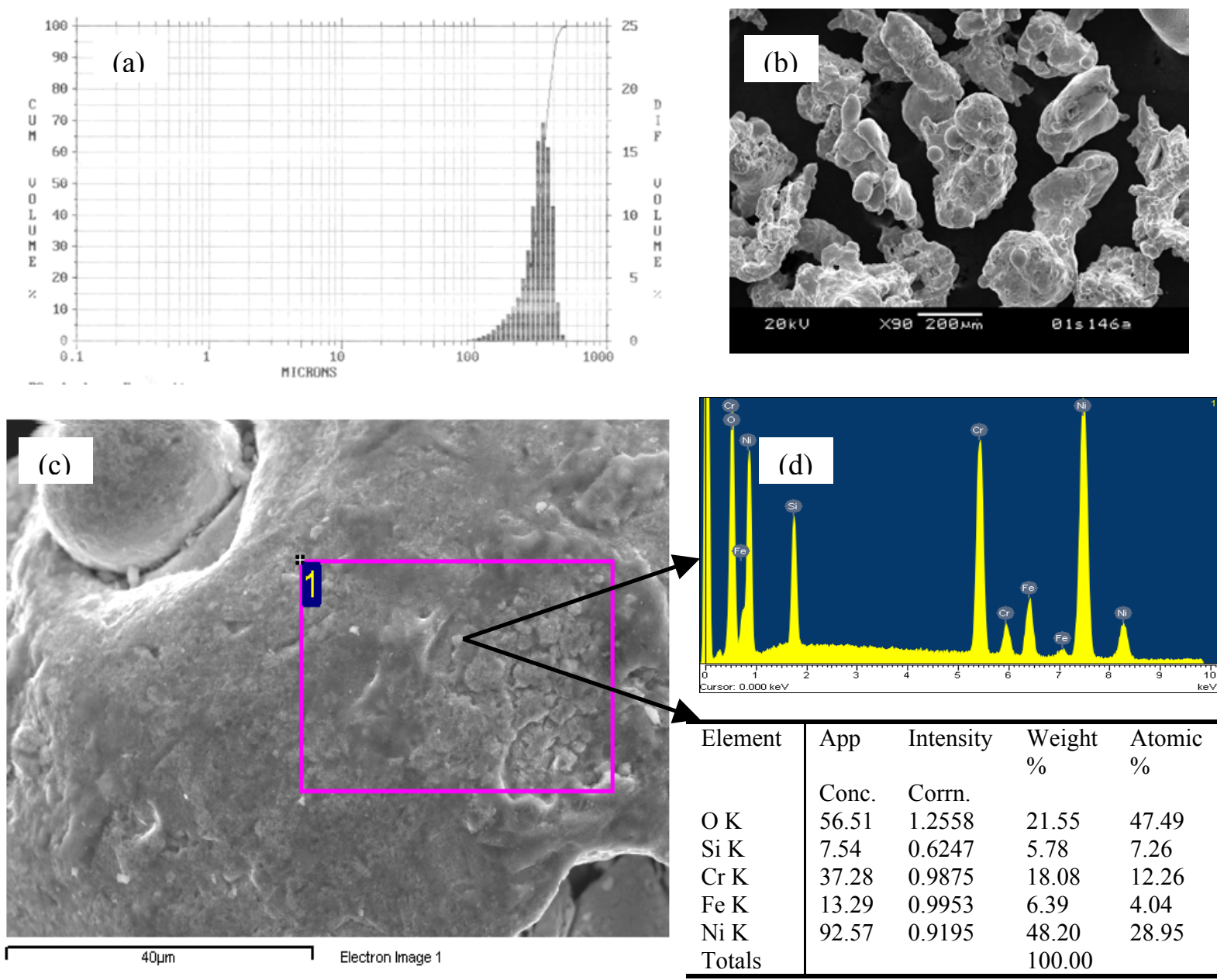

Figure 3-5. a) Particle Size, b) SEM, c) Point EDS area, and d) EDS Data of Inconel 600 Powder

\subsection{Selection and Preparation of Glasses}

Two glasses, shown in Table 3.1, were chosen for this study. MS-7 (a simplified version of a typical Hanford HLW glass with a liquidus temperature, $\mathrm{T}_{\mathrm{L}}$, of $1078^{\circ} \mathrm{C}$ ) was chosen as it had been used as a model high-level waste glass in recent spinel settling studies at PNNL. Modified NCAW was chosen as several melter studies had already reported using this composition.

Glasses were made from oxides, carbonates, and boric acid. These batch chemicals were milled for $5 \mathrm{~min}$ in an agate mill and melted for $1 \mathrm{~h}$. The glass was quenched on a steel pour plate, then ground in a tungsten carbide mill for 4 min and remelted to ensure homogeneity. 
Table 3-1. Target Glass Compositions

MS-7

\begin{tabular}{|c|c|}
\hline Oxide & Wt \% \\
\hline $\mathrm{Al}_{2} \mathrm{O}_{3}$ & 8.00 \\
\hline $\mathrm{B}_{2} \mathrm{O}_{3}$ & 7.00 \\
\hline $\mathrm{Cr}_{2} \mathrm{O}_{3}$ & 0.30 \\
\hline $\mathrm{Fe}_{2} \mathrm{O}_{3}$ & 11.50 \\
\hline $\mathrm{Li}_{2} \mathrm{O}$ & 4.54 \\
\hline $\mathrm{MgO}$ & 0.60 \\
\hline $\mathrm{MnO}$ & 0.50 \\
\hline $\mathrm{Na}_{2} \mathrm{O}$ & 15.30 \\
\hline $\mathrm{NiO}$ & 0.95 \\
\hline $\mathrm{SiO}_{2}$ & 45.31 \\
\hline $\mathrm{ZrO}_{2}$ & 6.00 \\
\hline Total & 100.00 \\
\hline
\end{tabular}

\section{Modified NCAW}

\begin{tabular}{lc}
\hline Oxide & Wt \% \\
\hline $\mathrm{SiO}_{2}$ & 52.97 \\
$\mathrm{~B}_{2} \mathrm{O}_{3}$ & 14.99 \\
$\mathrm{Li}_{2} \mathrm{O}$ & 5.34 \\
$\mathrm{Al}_{2} \mathrm{O}_{3}$ & 2.57 \\
$\mathrm{CaO}$ & 0.23 \\
$\mathrm{CdO}$ & 0.87 \\
$\mathrm{CeO}_{2}$ & 0.18 \\
$\mathrm{Cl}^{-}$ & 0.08 \\
$\mathrm{Cr}_{2} \mathrm{O}_{3}$ & 0.07 \\
$\mathrm{Cs}_{2} \mathrm{O}$ & 0.17 \\
$\mathrm{CuO}$ & 0.07 \\
$\mathrm{Fe}_{2} \mathrm{O}_{3}$ & 8.06 \\
$\mathrm{La}_{2} \mathrm{O}_{3}$ & 0.19 \\
$\mathrm{MgO}$ & 0.10 \\
$\mathrm{MnO}_{2}$ & 0.61 \\
$\mathrm{MoO}_{3}$ & 0.16 \\
$\mathrm{Na}_{2} \mathrm{O}$ & 6.10 \\
$\mathrm{Nd}_{2} \mathrm{O}_{3}$ & 0.99 \\
$\mathrm{NiO}_{2}$ & 0.66 \\
$\mathrm{P}_{2} \mathrm{O}_{5}$ & 0.25 \\
$\mathrm{PbO}_{2}$ & 0.20 \\
$\mathrm{ReO}_{2}$ & 0.10 \\
$\mathrm{RuO}_{2}$ & 0.11 \\
$\mathrm{SiO}_{2}$ & 0.14 \\
$\mathrm{SO}_{3}$ & 0.19 \\
$\mathrm{TiO}_{2}$ & 0.19 \\
$\mathrm{ZnO}_{2 \mathrm{ZO}}$ & 0.10 \\
$\mathrm{Trtal}_{2}$ & 4.31 \\
\hline & $\mathbf{1 0 0 . 0 0}$ \\
\hline
\end{tabular}

\subsection{Double Crucibles Test}

Klouzek and coworkers (Klouzek et al. 2001) used a double crucible assembly, a smaller alumina crucible placed inside a larger silica crucible (shown in Figure 3.6). This assembly was used to minimize Marangoni convection and bubble generation within the inner crucible (LaMont and Hrma, 1998). MS-7 glass melt was poured into preheated crucibles until the top of the inner crucible was just covered with the 
melt. The crucible assembly was then placed back into the furnace at $1220^{\circ} \mathrm{C}$. After $20 \mathrm{~min}$., the temperature was lowered to the test temperatures, for increasing time intervals (up to $30 \mathrm{~h}$ ), and then cooled. The test conditions are listed in Table 3.2. Vertical thin sections were prepared to investigate the area inside the alumna crucible. Crystals were studied using an Olympus PMG3 microscope and Clemex Image Analyzer.

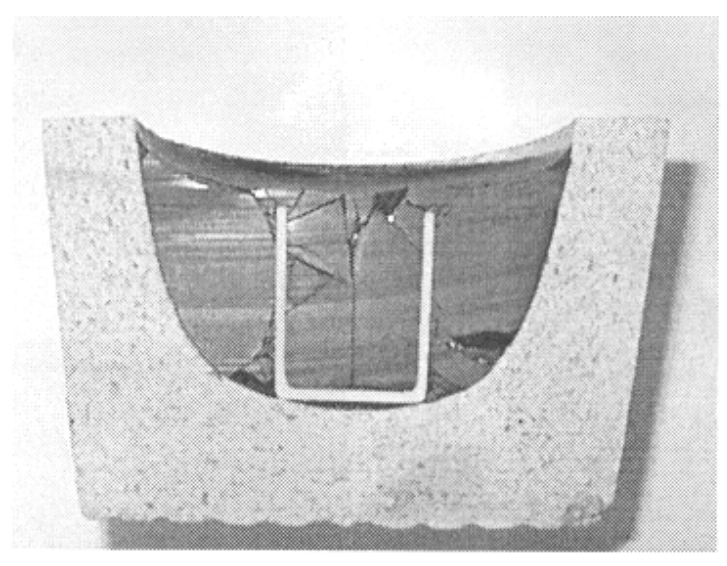

Figure 3-6. Double Crucible Test (Klouzek et al. 2001)

Table 3-2. Test Parameters

\begin{tabular}{lc}
\hline Parameters & Values \\
\hline Oxides & $\mathrm{RuO}_{2}, \mathrm{WO}_{3}$ \\
Concentrations (nominal wt \%) & $0.005,0.5,1.0$ \\
Temperature $\left({ }^{\circ} \mathrm{C}\right)$ & $900,950,1000$ \\
Time (hours) & $7,15,19,23$ \\
\hline
\end{tabular}

In addition, $\mathrm{NiCr}_{2} \mathrm{O}_{4}$ was also tested to a limited extent $\left(0.1\right.$ and $0.5 \mathrm{wt} \%$ at $950^{\circ} \mathrm{C}$ and $1050^{\circ} \mathrm{C}$ for 15-23 h.) in modified NCAW glass melt. Quick tests showed that $\mathrm{Cr}_{2} \mathrm{O}_{3}$ dissolved easily into the model systems and Inconel 600 powders settled shortly after their addition to the test melts. Therefore, $\mathrm{Cr}_{2} \mathrm{O}_{3}$ and Inconel 600 were not further investigated.

\subsection{Crystallization Studies}

In order to compare the role of $\mathrm{RuO}_{2}$ and $\mathrm{WO}_{3}$ in spinel crystallization (Plaisted et al. 2001), samples of MS-7 glass with $0.5 \mathrm{wt} \%$ of $\mathrm{RuO}_{2}$ or $\mathrm{WO}_{3}$ for crystallization studies were heat-treated in $2 \times 2$ $\times 2 \mathrm{~cm}$ platinum crucibles at 900,950 , and $1000^{\circ} \mathrm{C}$ for $7-23 \mathrm{~h}$. The heat-treated samples were characterized by using x-ray diffraction (XRD). Qualitative XRD data are presented in this report.

\subsection{Viscosity Tests}

Modified NCAW glass was used for these tests. The rheology of the melts containing 1 and 10 wt. $\%$ of $\mathrm{NiCr}_{2} \mathrm{O}_{4}$, was studied using a Brookfield digital rotating viscometer with a disk spindle (Mika and Hrma 2000). The temperature ranged from $1050^{\circ} \mathrm{C}$ to $1350^{\circ} \mathrm{C}$, and the spindle speed, from 0.005 to 1 RPS. Before each measurement, the sample was held for $90 \mathrm{~min}$ at the measuring temperature. The idle time for spindle-speed change was $5 \mathrm{~min}$ and for temperature change $30 \mathrm{~min}$. The lower surface of the 
spindle was about $13 \mathrm{~mm}$ above the crucible bottom. The shear stress ( $\tau=M / 2 \pi R_{d} L$, where $M=$ torque, $\mathrm{R}_{\mathrm{d}}=$ spindle radius, $7.3 \mathrm{~mm}$, and $\mathrm{L}=$ spindle height, $2 \mathrm{~mm}$ ) was determined ${ }^{\mathrm{h}}$.

\subsection{High Temperature Optical Microscopy}

High temperature optical microscopy was used to study the suspension of $\mathrm{RuO}_{2}$ and $\mathrm{NiCr}_{2} \mathrm{O}_{4}$. The hot stage designed and developed in-house (shown in Figure 3.7) was used. The stage was place on the platform of the optical microscope (Metallux II, Leco Corporation) with the crucible with the test glass. Test melt (MS-7) with $1 \mathrm{wt} . \%$ of $\mathrm{RuO}_{2}$ or $\mathrm{NiCr}_{2} \mathrm{O}_{4}$ powder added was observed from room temperature to about $1100^{\circ} \mathrm{C}$. The melt changes were photographed.

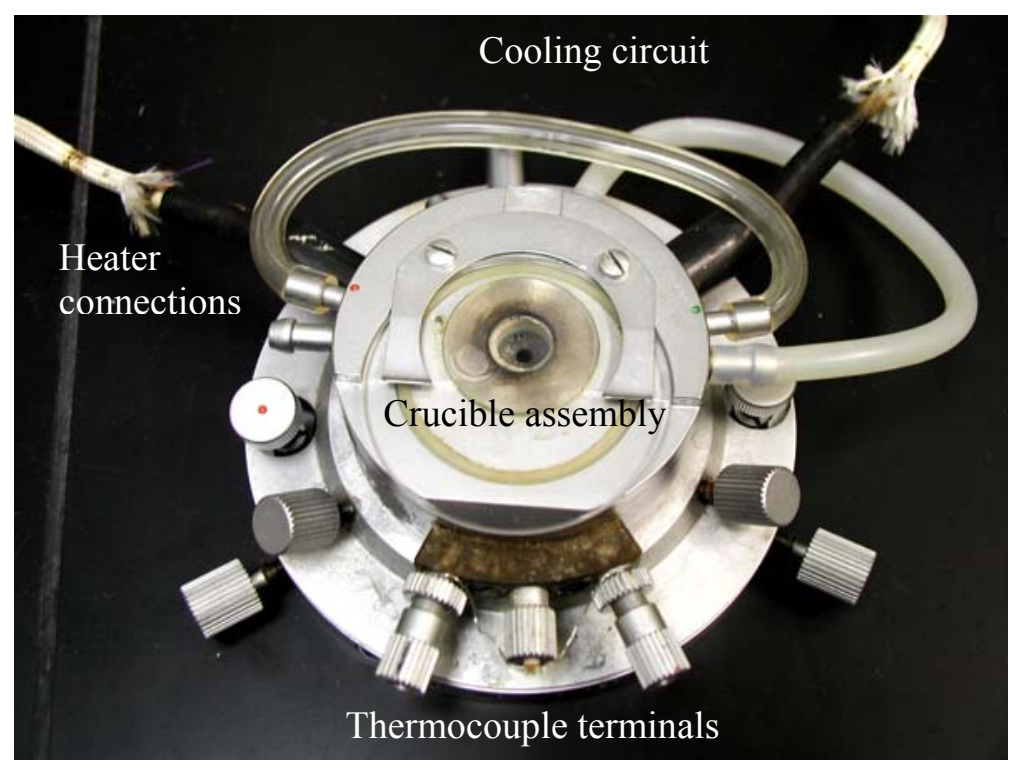

Figure 3-7. Hot Optical Microscopy Stage

\subsection{Partition Stuides}

Partitioning of noble metal species $\left(\mathrm{Ru}\right.$ and $\left.\mathrm{RuO}_{2}\right)$ and the surrogate species $\left(\mathrm{W}\right.$ and $\left.\mathrm{WO}_{3}\right)$ between spinel $\left(\mathrm{MgAl}_{2} \mathrm{O}_{4}\right)$ and model glass melt (MS-7) was studied following the same technique followed by Capobianco and Drake (Capobianco and Drake, 1990). Capsules made from single crystal synthesized spinel boules (grown by the flame fusion method, i.e., Verneuil process) commercially available. The capsule spinel was chosen for its easy availability and its prior use for partition study. The starting capsule is non-stoichiometric spinel $\left(90 \mathrm{wt} . \% \mathrm{Al}_{2} \mathrm{O}_{3}\right.$ and $\left.10 \mathrm{wt} . \% \mathrm{MgO}\right)$. In the preparation of the spinel capsule, a slice was cut from the boule and a hole was drilled into the slice (Figure 3.8 (a) - (c)). Then, the hole was packed with the glass powder with suitable additive and suspended using platinum wire wound around an alumina rod (Figure 3.8(d)). Several samples were assembled in a ceramic trough, as shown in Figure 3.8(e).

About 2 gm of MS-7 glass was mixed with 0.5 wt. $\%$ of the species $\left(\mathrm{Ru}, \mathrm{RuO}_{2}, \mathrm{~W}, \mathrm{WO}_{3}\right)$ and placed into the capsule. The assembly of capsules were heated to $1220^{\circ} \mathrm{C}$ and held at that temperature for

\footnotetext{
${ }^{\mathrm{h}}$ Brookfield Viscometer Guide, Brookfield Engineering Laboratories, Brookfield, MA, USA.

${ }^{\mathrm{i}}$ Supplier: Morion Company, Birghton, MA, USA.
} 
$20 \mathrm{~min}$. Then, the temperature was decreased to the test temperatures $\left(900^{\circ} \mathrm{C}\right.$ and $\left.1000^{\circ} \mathrm{C}\right)$ for $7-23 \mathrm{~h}$. After the completion of the heat-treatment, the capsule was cooled to room temperature and sectioned at the middle. The cross section of the capsule with the glass melt was prepared for SEM and EDS. EDS scans (along a line at and across the spinel-melt interfacial region) were done to determine the extent of the spinel-melt interaction and chemistry change across the interface.
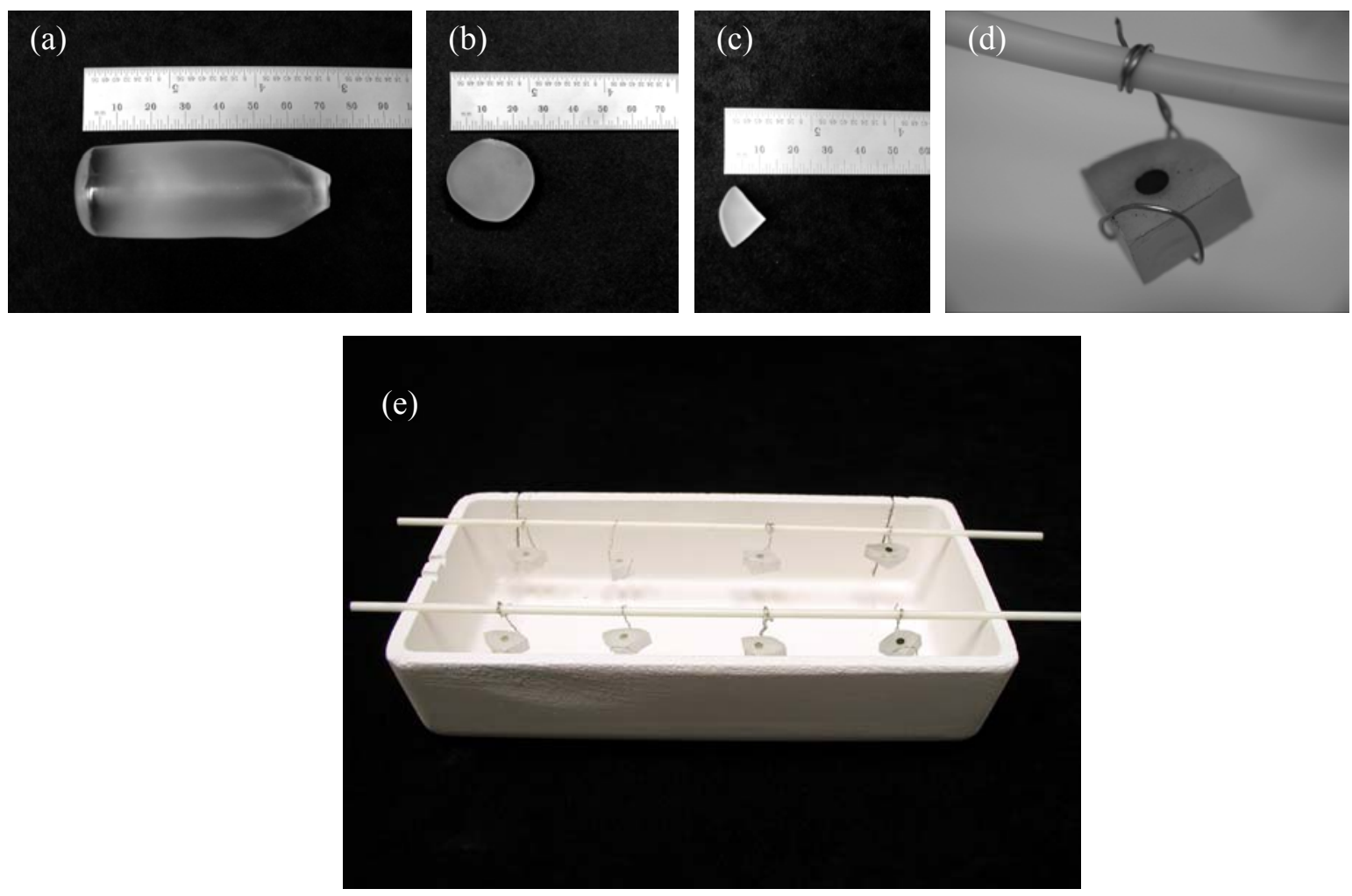

Figure 3-8. Capsule and Sample Preparation for Partition Study

\subsection{AC Conductivity Test}

AC electrical conductivity (at $60 \mathrm{~Hz}$ ) of the DWPF frit glass samples with 1, 2, 5, and $10 \mathrm{wt} . \%$ of the conductivity surrogates (Inconel $600, \mathrm{Cr}_{2} \mathrm{O}_{3}, \mathrm{NiCr}_{2} \mathrm{O}_{4}$ ), $\mathrm{RuO}_{2}$ and $\mathrm{WO}_{3}$ at $950-1250^{\circ} \mathrm{C}$ was measured using two-probe technique. 


\subsection{Results and Discussion}

\subsection{Double Crucible Tests}

\subsection{1 $\mathrm{RuO}_{2}$ vs. $\mathrm{WO}_{3}$ in $\mathrm{MS}-7$}

Figure 4.1 shows the thin sections of the inner crucible containing the test glasses with $0.5 \mathrm{wt} . \%$ $\mathrm{RuO}_{2}$ or $\mathrm{WO}_{3}$ at test temperatures for $7-23 \mathrm{~h}$. At $900^{\circ} \mathrm{C}, \mathrm{RuO}_{2}$, spinel crystals formed sparingly. In the case of $\mathrm{WO}_{3}$, more spinel crystals (dark spots) were clearly seen at $950^{\circ} \mathrm{C}$, especially after $19 \mathrm{~h}$. The temperature effect was more pronounced. In either case, more spinel crystals formed at $950^{\circ} \mathrm{C}$ and started settling at $1000^{\circ} \mathrm{C}$, as shown in Figure 4.2.

Selected areas of the samples (especially near the wall of the inner crucible) were characterized using SEM and EDS. Figures 4.3 and 4.4 show features of sample containing $0.5 \mathrm{wt} . \%$ of $\mathrm{RuO}_{2}$ heattreated at $950^{\circ} \mathrm{C}$ for $23 \mathrm{~h}$. Area 1 in Figure 4.3 represents bulk glass region. No measurable Ru was detected in this region. This was interpreted to be due to low solubility of $\mathrm{RuO}_{2}$ in glass as well as the detectability limit of the EDS technique. Spinel crystals (about $2-5 \mu \mathrm{m}$ size) were seen in the sample. The crystal on right side of Figure 4.3 was Fe-Ni spinel with about 3.56 wt.\% of Ru. In Figure 4.4, the crystal on the left side was Fe-Ni spinel with no detectable Ru. The area marked 4 on the right side of Figure 4.4 was an alkali silicate phase containing Fe and $\mathrm{Zr}$ along with about $7.65 \mathrm{wt} . \%$ of $\mathrm{Ru}$.

Figure 4.5 shows features of sample containing $0.5 \mathrm{wt} . \%$ of $\mathrm{WO}_{3}$ heat-treated at $950^{\circ} \mathrm{C}$ for $23 \mathrm{~h}$. Area 1 represents bulk glass region. The crystal was Fe-Ni spinel (about 20-50 $\mu \mathrm{m}$ size). No measurable $\mathrm{W}$ was detected in these regions. This was also interpreted to be due to low solubility of $\mathrm{RuO}_{2}$ in glass as well as the detectability limit of the EDS technique. On comparing these observations with Figures 4.3 and 4.4, the data suggested $\mathrm{RuO}_{2}$ partitioned in spinel more readily.

Figure 4.6 shows features of sample containing $1 \mathrm{wt} . \%$ of $\mathrm{RuO}_{2}$ heat-treated at $950^{\circ} \mathrm{C}$ for $23 \mathrm{~h}$. Area 1 represents bulk glass region. Islands of segregated Ru-rich regions were observed. These regions clearly indicated supersaturation of the melt with $\mathrm{Ru}$. Based on these results, all partition studies (section 4.5 ) used $0.5 \mathrm{wt} . \%$ of $\mathrm{RuO}_{2}$ or $\mathrm{WO}_{3}$.

\subsection{2 $\mathrm{NiCr}_{2} \mathrm{O}_{4}$ in Modified $\mathrm{NCAW}$}

Figures 4.7, 4.8, and 4.9 show the thin sections of test glasses containing $0.1,0.5$, and $1 \mathrm{wt} . \%$ of $\mathrm{NiCr}_{2} \mathrm{O}_{4}$ at test temperatures for 15-25 h, respectively. In the case of $0.1 \mathrm{wt} \%$ (Figure 4.7), the spinel crystals (dark spots) appeared after $15 \mathrm{~h}$ but reduced in number after $23 \mathrm{~h}$, suggesting redissolution of the crystals in the melts. Relatively more spinel crystals were observed with $0.5 \mathrm{wt} \%$ of $\mathrm{NiCr}_{2} \mathrm{O}_{4}$ (Figure 4.8). Addition of more $\mathrm{NiCr}_{2} \mathrm{O}_{4}$ (Figure 4.9) resulted in segregation of the crystals.

Figures 4.10-4.12 show SEM-EDS data of different regions for the sample containing $0.5 \mathrm{wt} . \%$ of $\mathrm{NiCr}_{2} \mathrm{O}_{4}$ heat-treated at $950^{\circ} \mathrm{C}$ for $23 \mathrm{~h}$. In Figure 4.10, region 1 represents the bulk glass. Several Ni-Cr spinel crystals clustered together. Different regions showed in Figures 4.11 and 4.12 contained various levels of $\mathrm{Ru}$. As the test glass contained $0.11 \mathrm{wt} . \% \mathrm{RuO}_{2}$, these observations supported our conclusion in the previous section (4.1.1) that Ru precipitated more readily in the presence of spinel. 


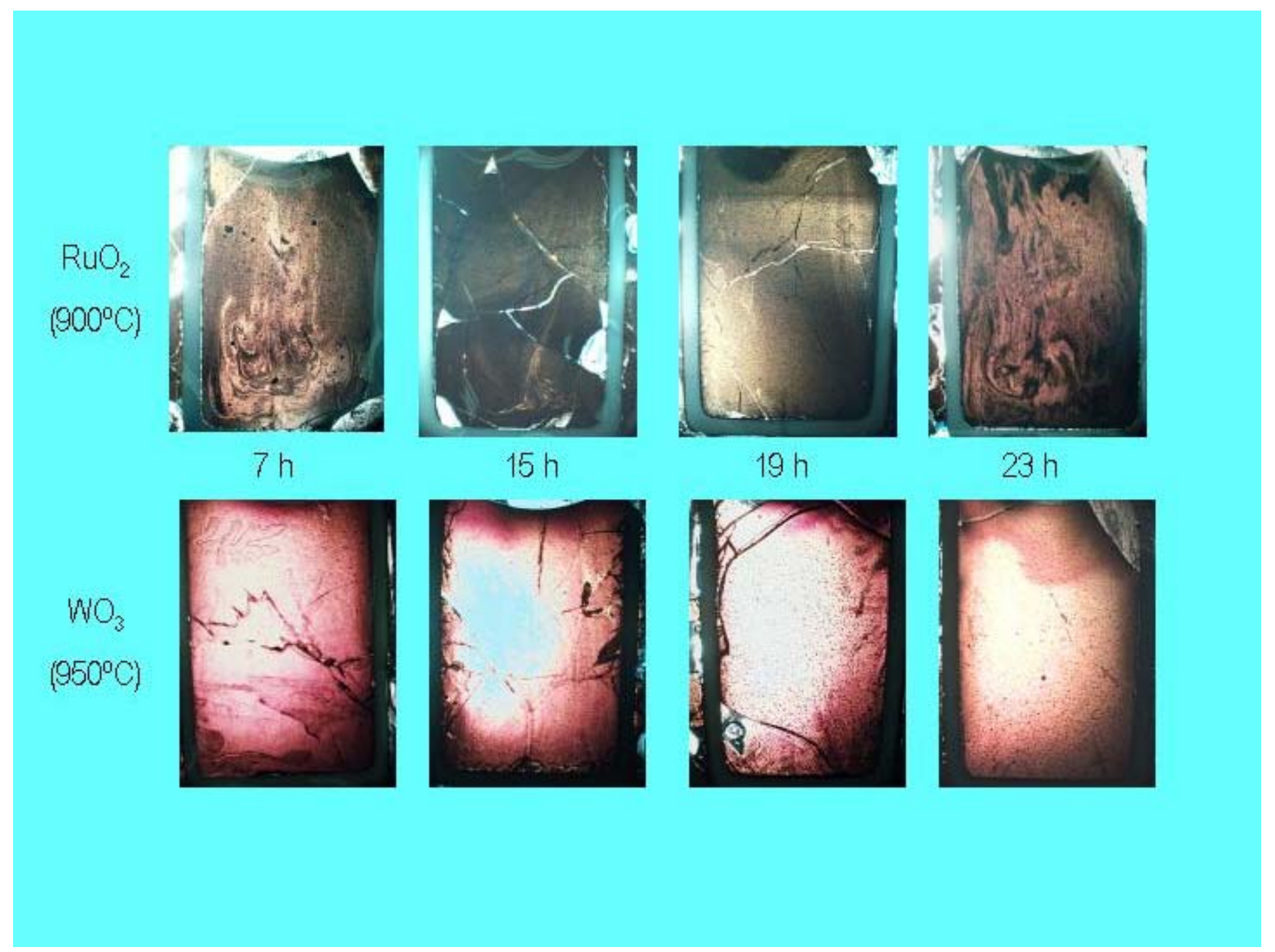

Figure 4-1. $\mathrm{RuO}_{2}$ vs. $\mathrm{WO}_{3}-$ Time Effect (0.5 wt.\% in MS-7) 


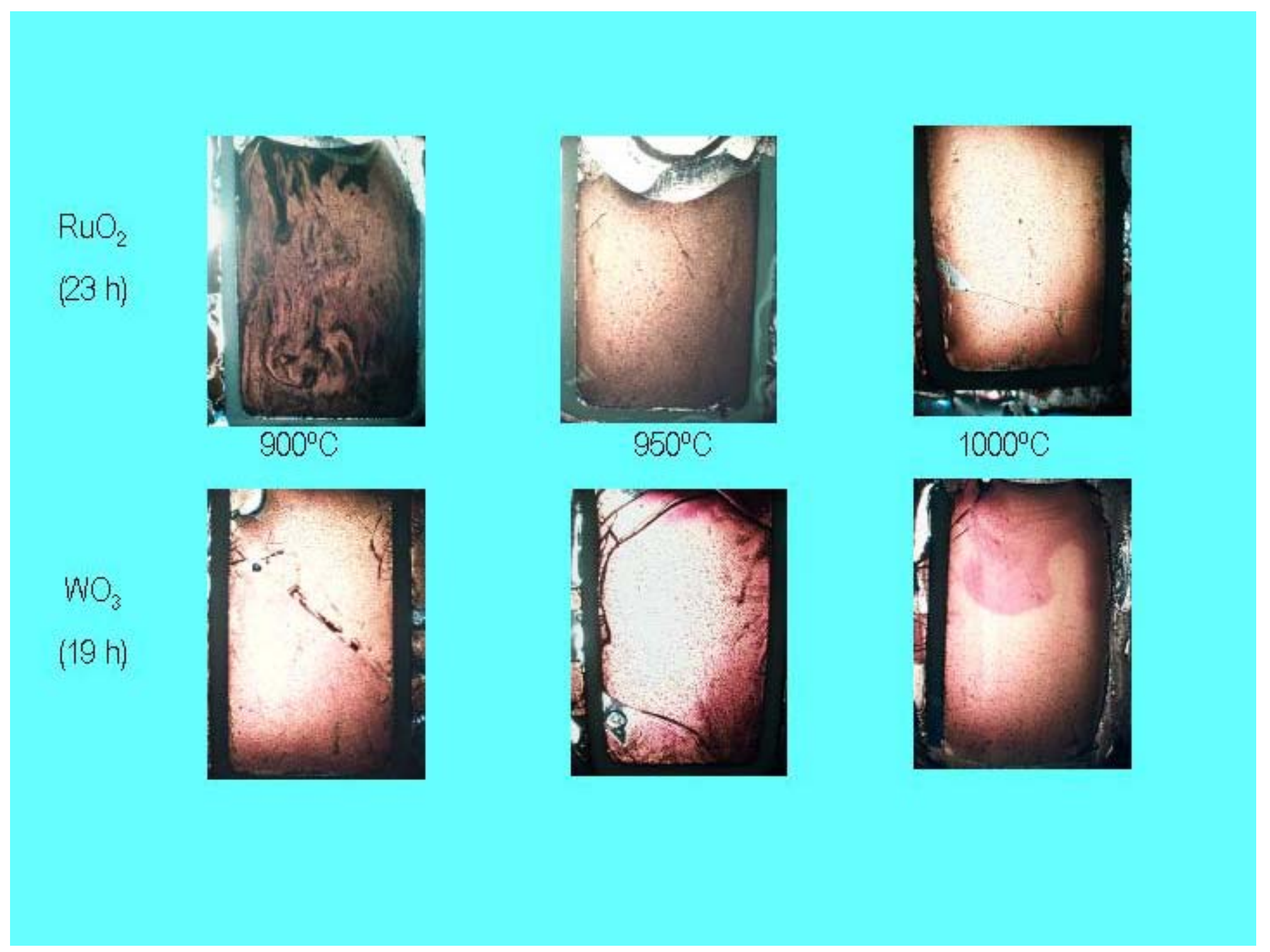

Figure 4-2. $\mathrm{RuO}_{2}$ vs. $\mathrm{WO}_{3}-$ Temperature Effect (0.5 wt. \% in MS-7) 


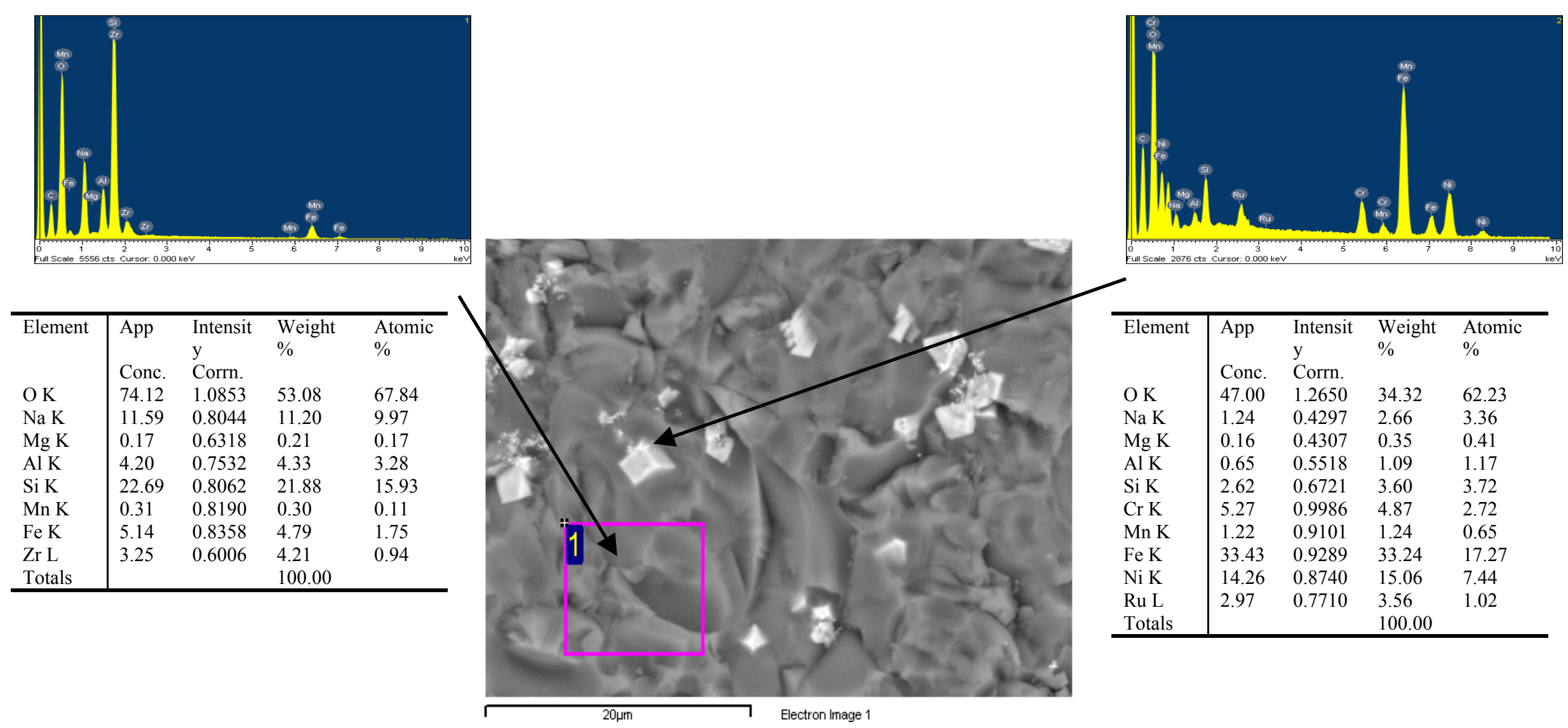

Figure 4-3. $\mathrm{SEM}-\mathrm{EDS}$ of $\mathrm{RuO}_{2}$ in $\mathrm{MS}-7\left(0.5 \mathrm{wt} . \%, 950^{\circ} \mathrm{C} / 23 \mathrm{~h}\right)$ 

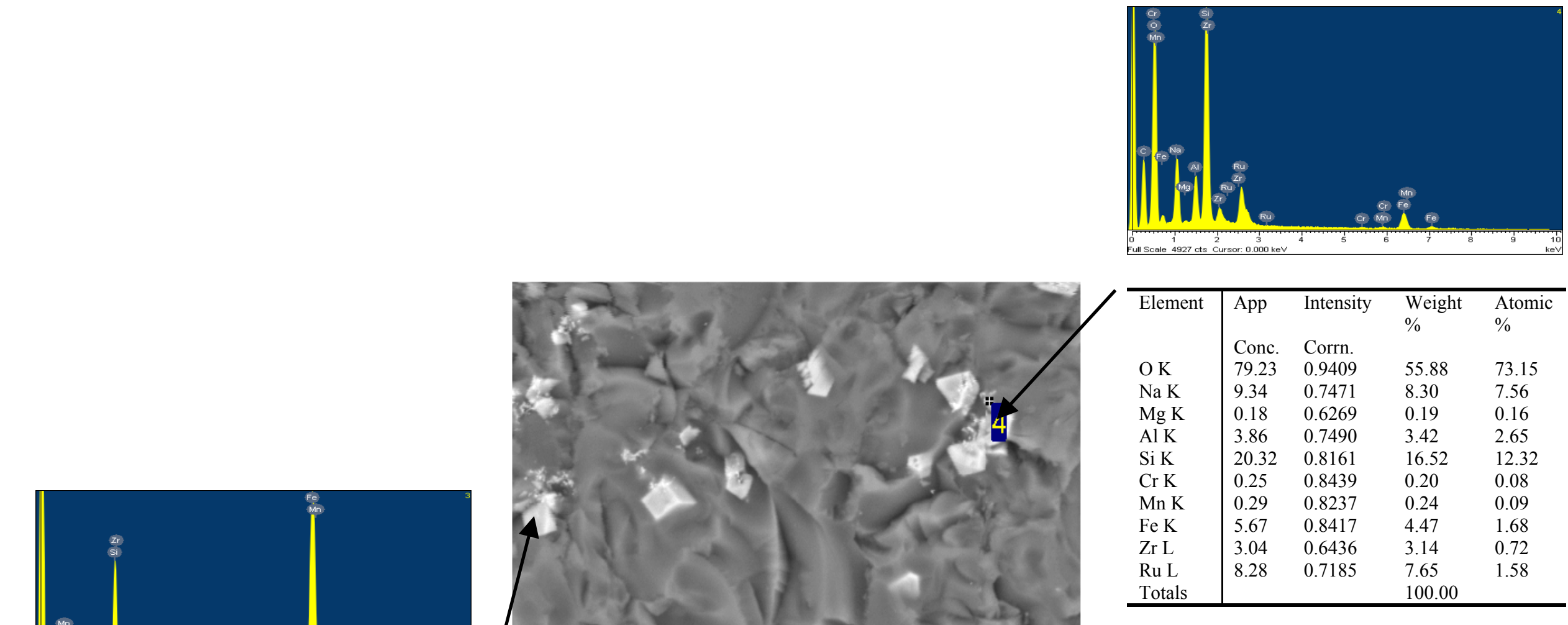

\begin{tabular}{|c|c|c|c|c|}
\hline Element & App & Intensity & $\begin{array}{l}\text { Weight } \\
\%\end{array}$ & $\begin{array}{l}\text { Atomic } \\
\%\end{array}$ \\
\hline O K & $\begin{array}{l}\text { Conc. } \\
7.27\end{array}$ & $\begin{array}{l}\text { Corrn. } \\
1.1287\end{array}$ & 10.85 & 26.57 \\
\hline $\mathrm{Na} \mathrm{K}$ & 0.68 & 0.4109 & 2.77 & 4.72 \\
\hline $\mathrm{Al} \mathrm{K}$ & 0.66 & 0.5351 & 2.08 & 3.02 \\
\hline Si K & 3.97 & 0.6514 & 10.26 & 14.32 \\
\hline $\mathrm{Cl} \mathrm{K}$ & 0.10 & 0.7455 & 0.24 & 0.26 \\
\hline $\mathrm{Cr} \mathrm{K}$ & 4.88 & 1.0446 & 7.87 & 5.93 \\
\hline Mn K & 0.85 & 0.9459 & 1.51 & 1.08 \\
\hline $\mathrm{Fe} \mathrm{K}$ & 24.85 & 0.9615 & 43.51 & 30.52 \\
\hline $\mathrm{Ni} \mathrm{K}$ & 10.28 & 0.8939 & 19.36 & 12.92 \\
\hline $\begin{array}{l}\mathrm{Zr} \mathrm{L} \\
\text { Totals }\end{array}$ & 0.56 & 0.6049 & $\begin{array}{l}1.56 \\
100.00\end{array}$ & 0.67 \\
\hline
\end{tabular}

Figure 4-4. $\mathrm{SEM}-\mathrm{EDS}$ of $\mathrm{RuO}_{2}$ in $\mathrm{MS}-7\left(0.5 \mathrm{wt} . \%, 950^{\circ} \mathrm{C} / 23 \mathrm{~h}\right)$ 


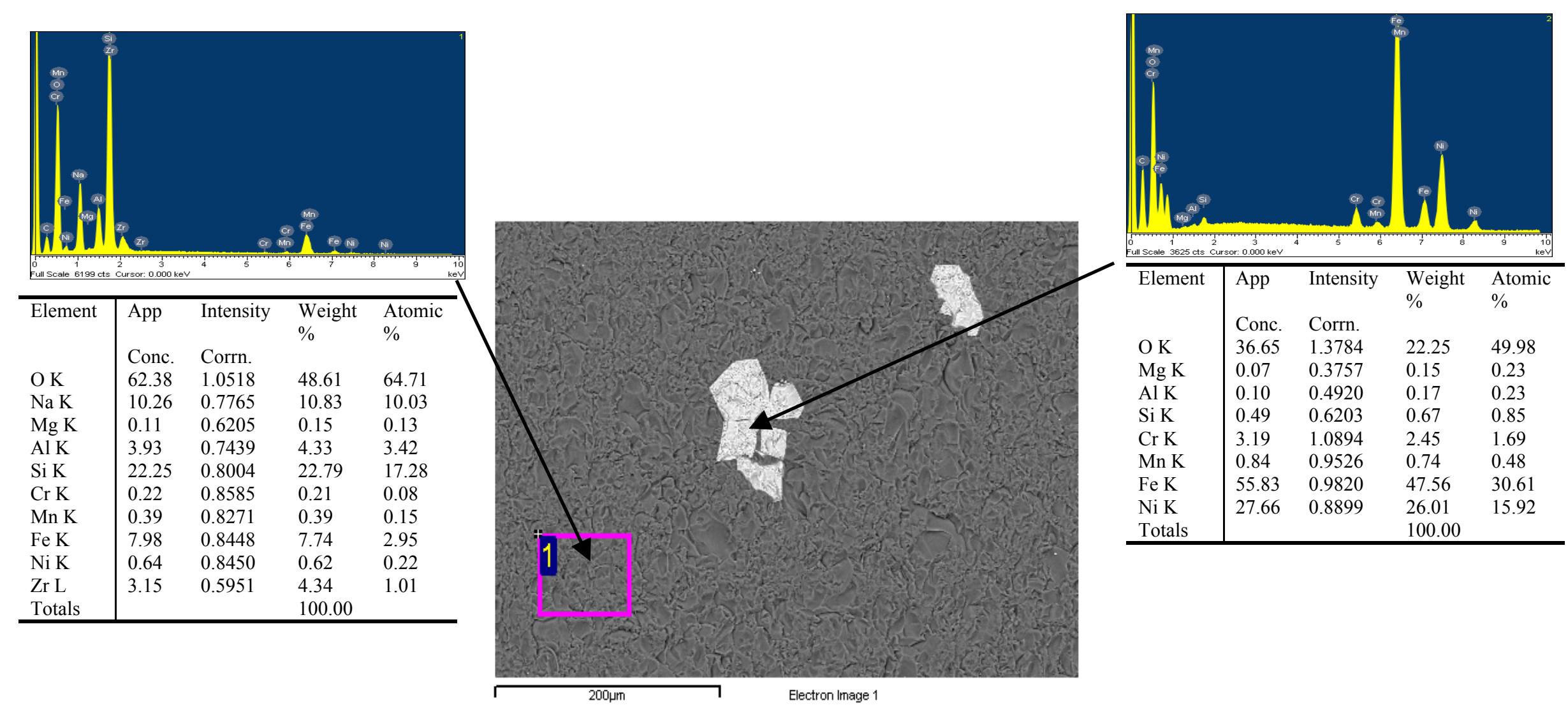

Figure 4-5. SEM -EDS of $\mathrm{WO}_{3}$ in $\mathrm{MS}-7\left(0.5 \mathrm{wt} . \%, 950^{\circ} \mathrm{C} / 23 \mathrm{~h}\right)$ 


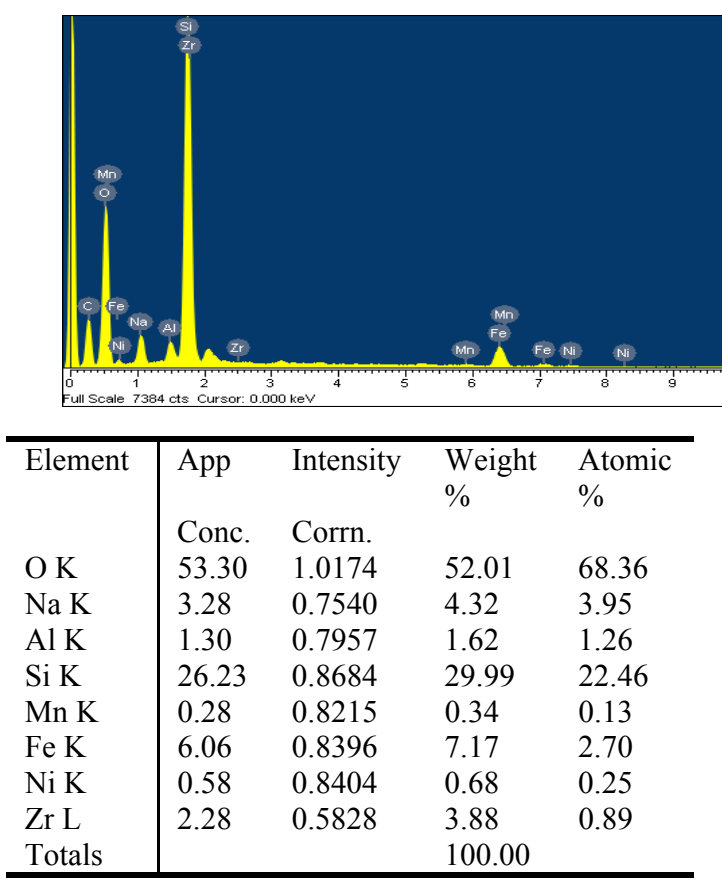

Figure 4-6. SEM -EDS of $\mathrm{RuO}_{2}$ in MS-7

$\left(1 \mathrm{wt} . \%, 950^{\circ} \mathrm{C} / 23 \mathrm{~h}\right)$
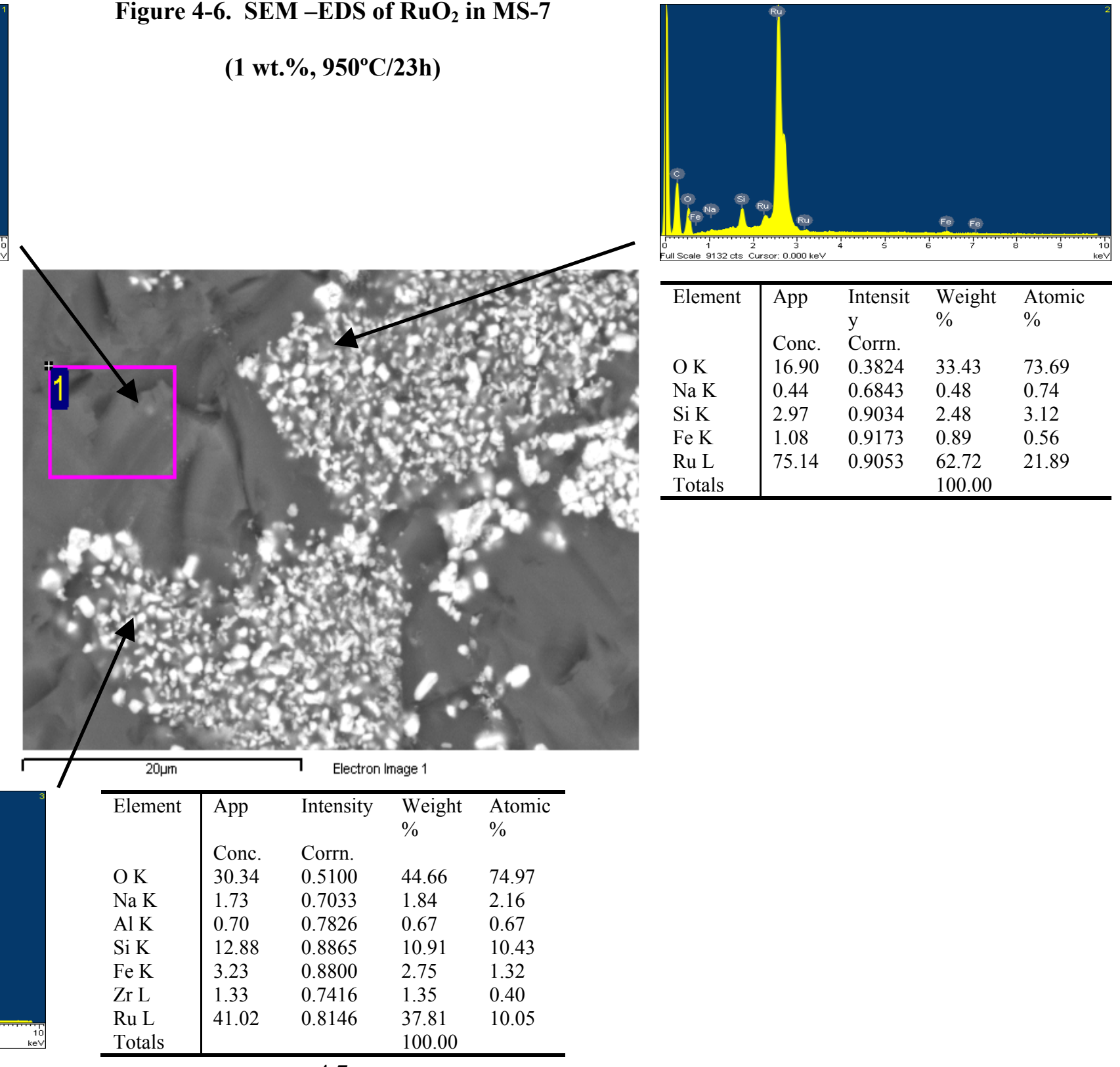

\begin{tabular}{|c|c|c|c|c|}
\hline Element & $\begin{array}{l}\text { App } \\
\text { Conc. }\end{array}$ & $\begin{array}{l}\text { Intensit } \\
\text { y } \\
\text { Corrn. }\end{array}$ & $\begin{array}{l}\text { Weight } \\
\%\end{array}$ & $\begin{array}{l}\text { Atomic } \\
\%\end{array}$ \\
\hline $\mathrm{OK}$ & 16.90 & 0.3824 & 33.43 & 73.69 \\
\hline $\mathrm{Na} \mathrm{K}$ & 0.44 & 0.6843 & 0.48 & 0.74 \\
\hline Si K & 2.97 & 0.9034 & 2.48 & 3.12 \\
\hline $\mathrm{Fe} \mathrm{K}$ & 1.08 & 0.9173 & 0.89 & 0.56 \\
\hline $\begin{array}{l}\mathrm{Ru} \mathrm{L} \\
\text { Totals }\end{array}$ & 75.14 & 0.9053 & $\begin{array}{l}62.72 \\
100.00\end{array}$ & 21.89 \\
\hline
\end{tabular}

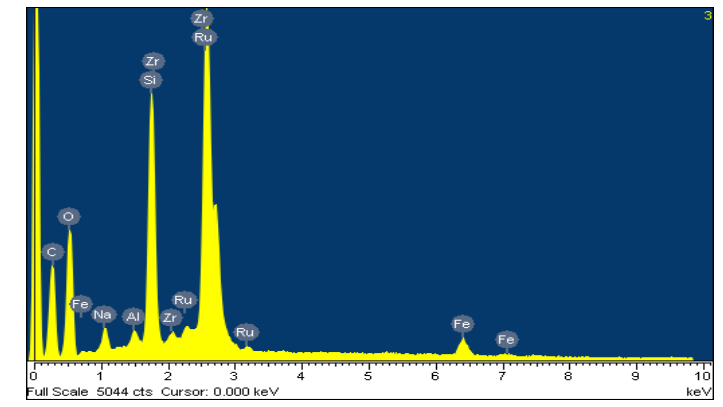

\begin{tabular}{l|llll}
\hline Element & App & Intensity & $\begin{array}{l}\text { Weight } \\
\%\end{array}$ & $\begin{array}{l}\text { Atomic } \\
\%\end{array}$ \\
& Conc. & Corrn. & & \\
$\mathrm{O} \mathrm{K}$ & 30.34 & 0.5100 & 44.66 & 74.97 \\
$\mathrm{Na} \mathrm{K}$ & 1.73 & 0.7033 & 1.84 & 2.16 \\
$\mathrm{Al} \mathrm{K}$ & 0.70 & 0.7826 & 0.67 & 0.67 \\
$\mathrm{Si} \mathrm{K}$ & 12.88 & 0.8865 & 10.91 & 10.43 \\
$\mathrm{Fe} \mathrm{K}$ & 3.23 & 0.8800 & 2.75 & 1.32 \\
$\mathrm{Zr} \mathrm{L}$ & 1.33 & 0.7416 & 1.35 & 0.40 \\
$\mathrm{Ru} \mathrm{L}$ & 41.02 & 0.8146 & 37.81 & 10.05 \\
Totals & & & 100.00 & \\
\hline
\end{tabular}

4.7 


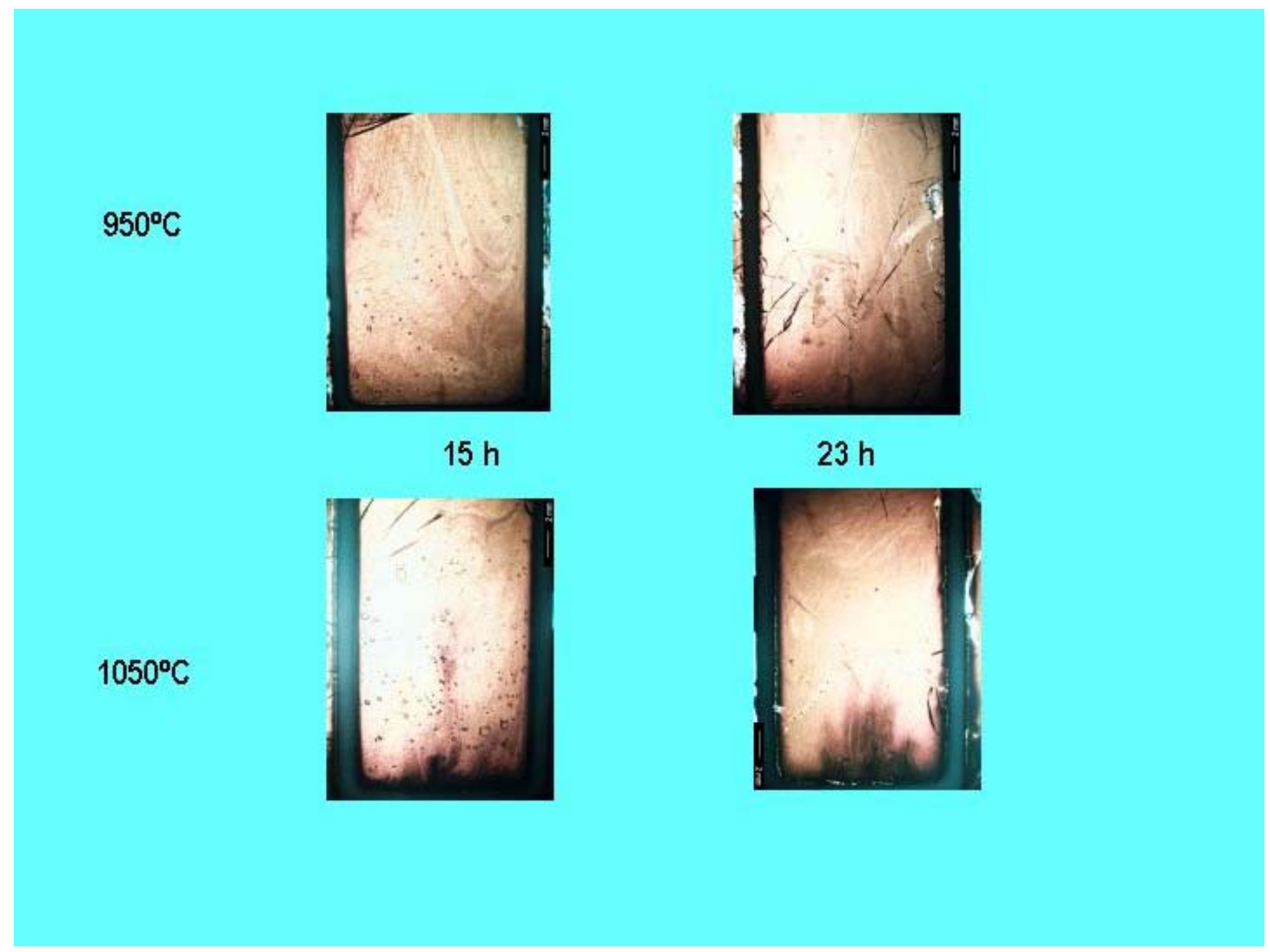

Figure 4-7. $0.1 \% \mathrm{NiCr}_{2} \mathrm{O}_{4}$ in Modifed NCAW 


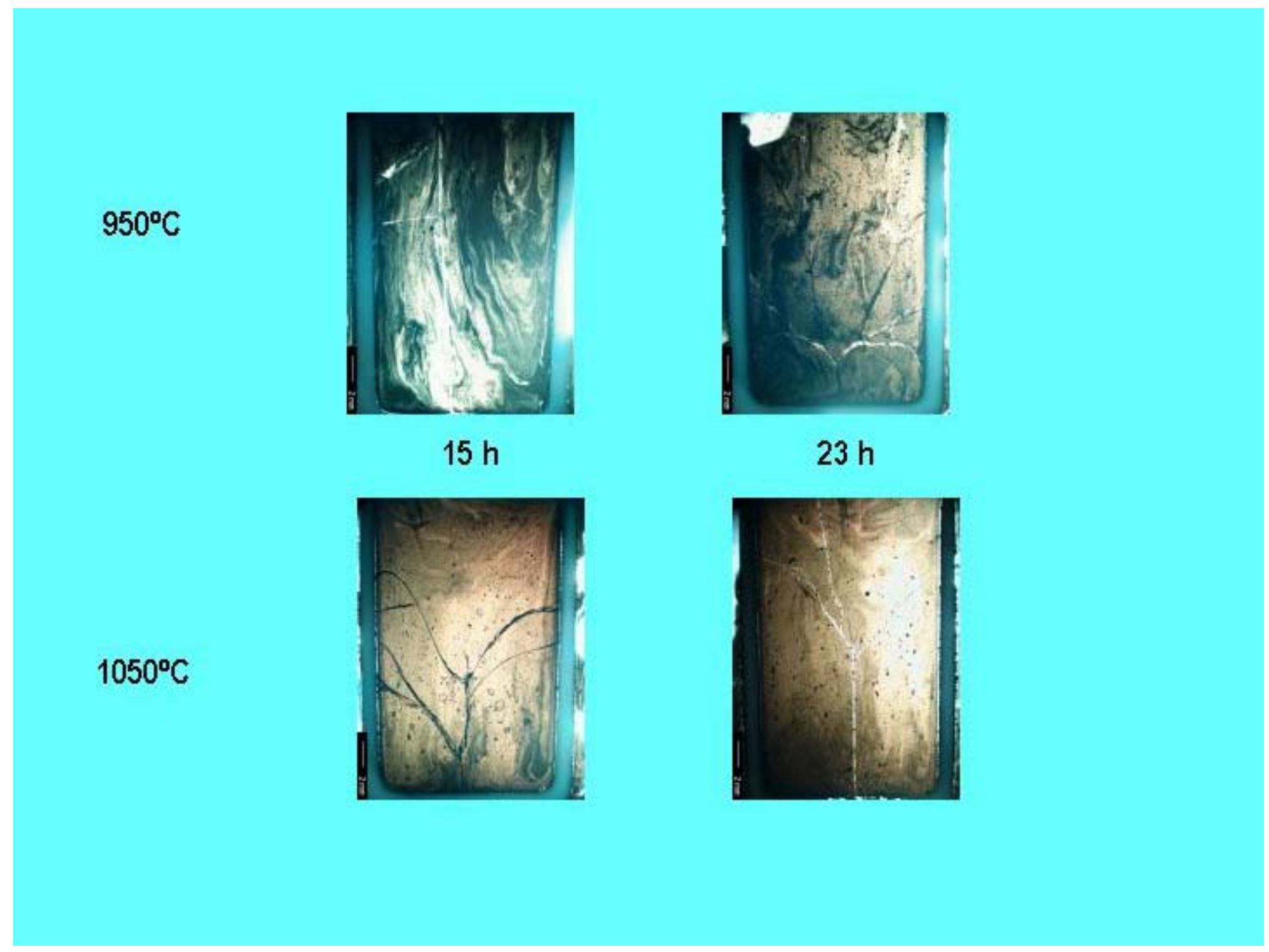

Figure 4-8. $0.5 \% \mathrm{NiCr}_{2} \mathrm{O}_{4}$ in Modified NCAW 


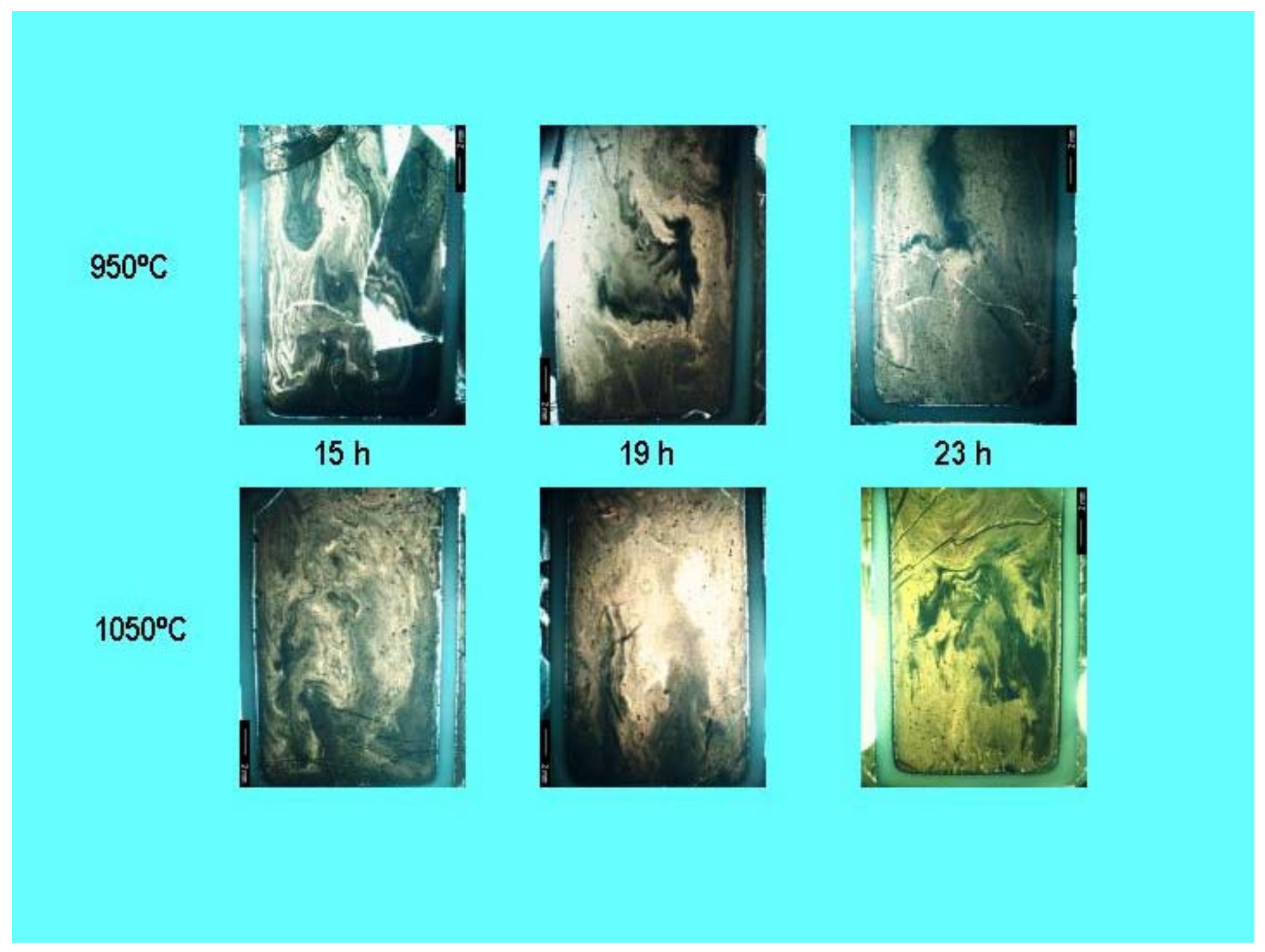

Figure 4-9. $1 \% \mathrm{NiCr}_{2} \mathrm{O}_{4}$ in Modifed NCAW 

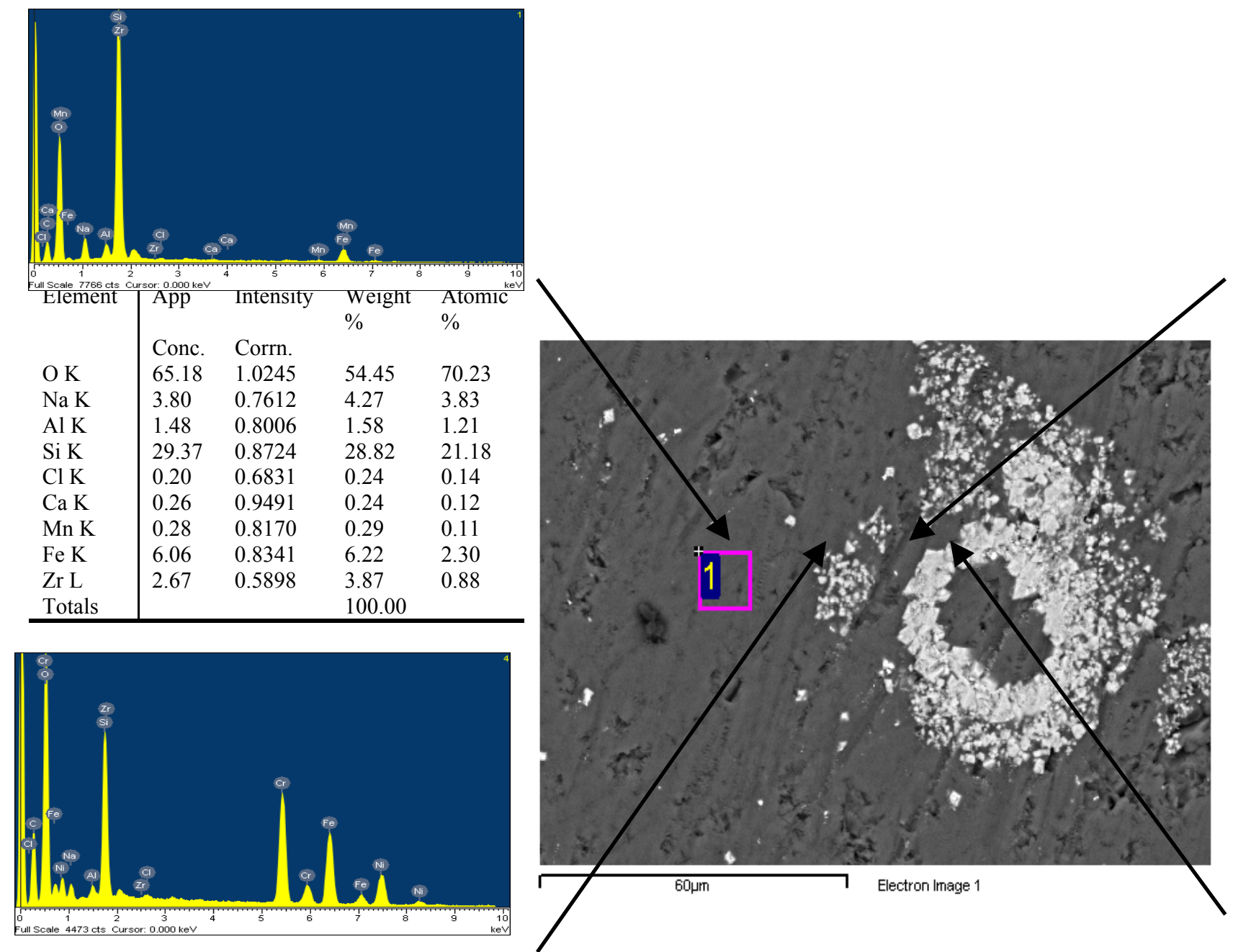

\begin{tabular}{l|llll}
\hline Element & App & Intensity & $\begin{array}{l}\text { Weight } \\
\%\end{array}$ & $\begin{array}{l}\text { Atomic } \\
\%\end{array}$ \\
& Conc. & Corrn. & & \\
O K & 76.59 & 1.3477 & 40.42 & 65.44 \\
Na K & 1.41 & 0.4915 & 2.04 & 2.30 \\
Al K & 0.67 & 0.6172 & 0.77 & 0.74 \\
Si K & 11.26 & 0.7342 & 10.91 & 10.06 \\
Cl K & 0.28 & 0.7590 & 0.26 & 0.19 \\
Cr K & 22.66 & 0.9291 & 17.35 & 8.64 \\
Fe K & 20.52 & 0.8787 & 16.61 & 7.70 \\
Ni K & 12.50 & 0.8617 & 10.32 & 4.55 \\
Zr L & 1.19 & 0.6436 & 1.31 & 0.37 \\
Totals & & & 100.00 & \\
\hline
\end{tabular}

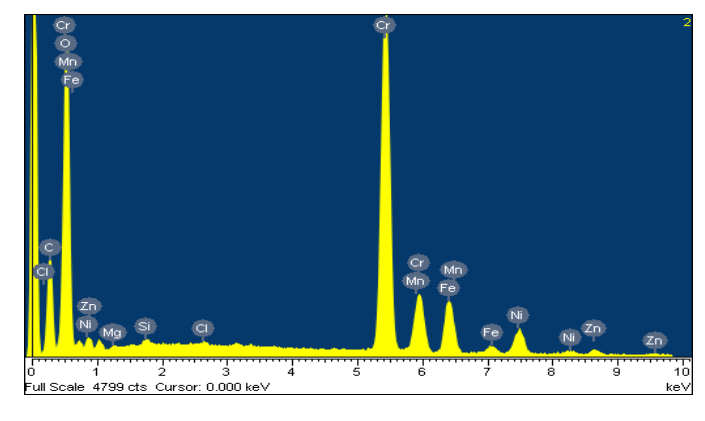

\begin{tabular}{l|llll}
\hline Element & App & Intensity & $\begin{array}{l}\text { Weight } \\
\%\end{array}$ & $\begin{array}{l}\text { Atomic } \\
\%\end{array}$ \\
& Conc. & Corrn. & & \\
O K & 71.48 & 1.6751 & 32.57 & 61.60 \\
$\mathrm{Mg} \mathrm{K}$ & 0.14 & 0.4489 & 0.23 & 0.29 \\
$\mathrm{Si} \mathrm{K}$ & 0.30 & 0.7063 & 0.33 & 0.35 \\
$\mathrm{Cl} \mathrm{K}$ & 0.15 & 0.8271 & 0.14 & 0.12 \\
$\mathrm{Cr} \mathrm{K}$ & 55.82 & 0.9477 & 44.95 & 26.16 \\
$\mathrm{Mn} \mathrm{K}$ & 3.11 & 0.9208 & 2.58 & 1.42 \\
$\mathrm{Fe} \mathrm{K}$ & 11.55 & 0.8613 & 10.23 & 5.55 \\
$\mathrm{Ni} \mathrm{K}$ & 7.79 & 0.8760 & 6.79 & 3.50 \\
Zn K & 2.42 & 0.8432 & 2.19 & 1.01 \\
Totals & & & 100.00 & \\
\hline
\end{tabular}

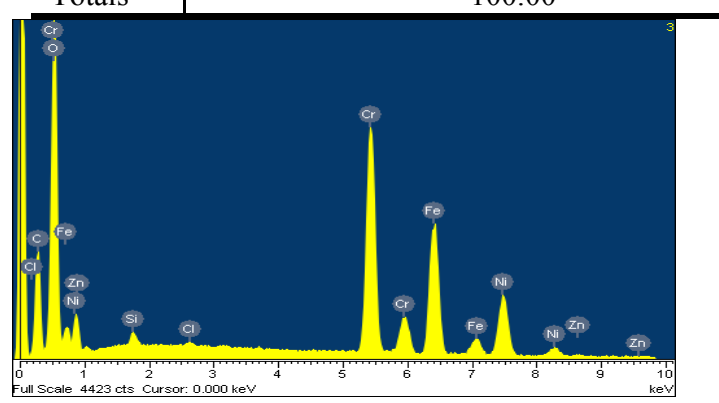

Figure 4-10. $0.5 \% \mathrm{NiCr}_{2} \mathrm{O}_{4}$ in Modifed $\mathrm{NCAW}$ $\left(950^{\circ} \mathrm{C} / 23 \mathrm{~h}\right)$

\begin{tabular}{|c|c|c|c|c|}
\hline Element & App & Intensity & $\begin{array}{l}\text { Weight } \\
\%\end{array}$ & $\begin{array}{l}\text { Atomic } \\
\%\end{array}$ \\
\hline $\mathrm{O} \mathrm{K}$ & $\begin{array}{l}\text { Conc. } \\
72.02\end{array}$ & $\begin{array}{l}\text { Corrn. } \\
1.5776\end{array}$ & 33.82 & 63.43 \\
\hline Si K & 0.60 & 0.6773 & 0.66 & 0.70 \\
\hline $\mathrm{Cl} \mathrm{K}$ & 0.18 & 0.8051 & 0.17 & 0.14 \\
\hline $\mathrm{Cr} \mathrm{K}$ & 35.13 & 0.9743 & 26.71 & 15.41 \\
\hline $\mathrm{Fe} \mathrm{K}$ & 27.42 & 0.8987 & 22.60 & 12.14 \\
\hline Ni K & 18.18 & 0.8758 & 15.37 & 7.86 \\
\hline Zn K & 0.76 & 0.8346 & 0.67 & 0.31 \\
\hline Totals & & & 100.00 & \\
\hline
\end{tabular}




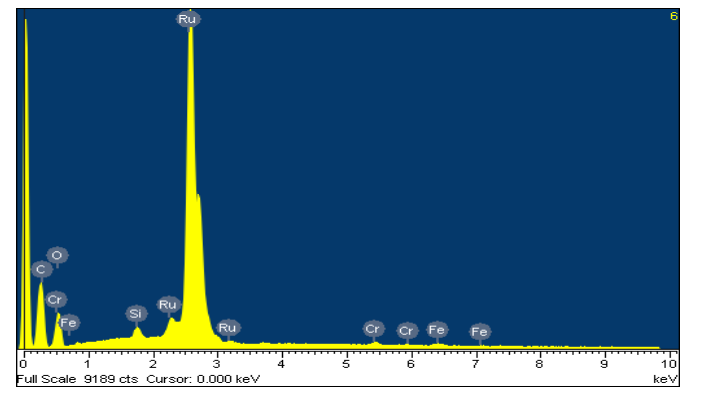

\begin{tabular}{l|llll}
\hline Element & App & Intensity & $\begin{array}{l}\text { Weight } \\
\%\end{array}$ & $\begin{array}{l}\text { Atomic } \\
\%\end{array}$ \\
& Conc. & Corrn. & & \\
O K & 15.10 & 0.3674 & 30.66 & 72.59 \\
Si K & 1.18 & 0.9053 & 0.98 & 1.32 \\
Cr K & 0.85 & 0.8780 & 0.72 & 0.53 \\
Fe K & 0.93 & 0.9251 & 0.75 & 0.51 \\
Ru L & 82.60 & 0.9209 & 66.89 & 25.06 \\
Totals & & & 100.00 & \\
\hline
\end{tabular}
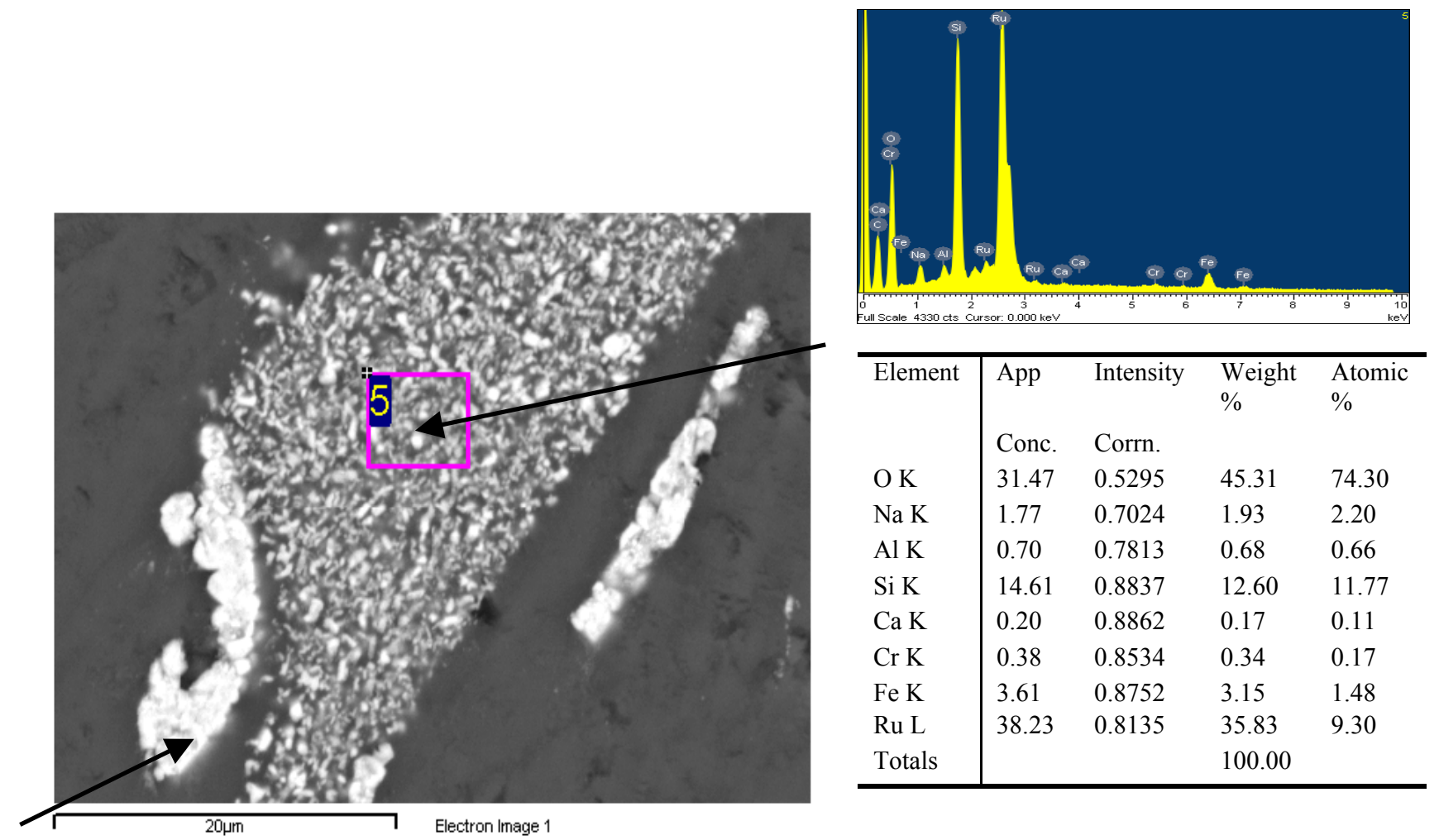

Figure 4-11. $0.5 \% \mathrm{NiCr}_{2} \mathrm{O}_{4}$ in Modifed NCAW $\left(950^{\circ} \mathrm{C} / 23 \mathrm{~h}\right)-$ Different Region 

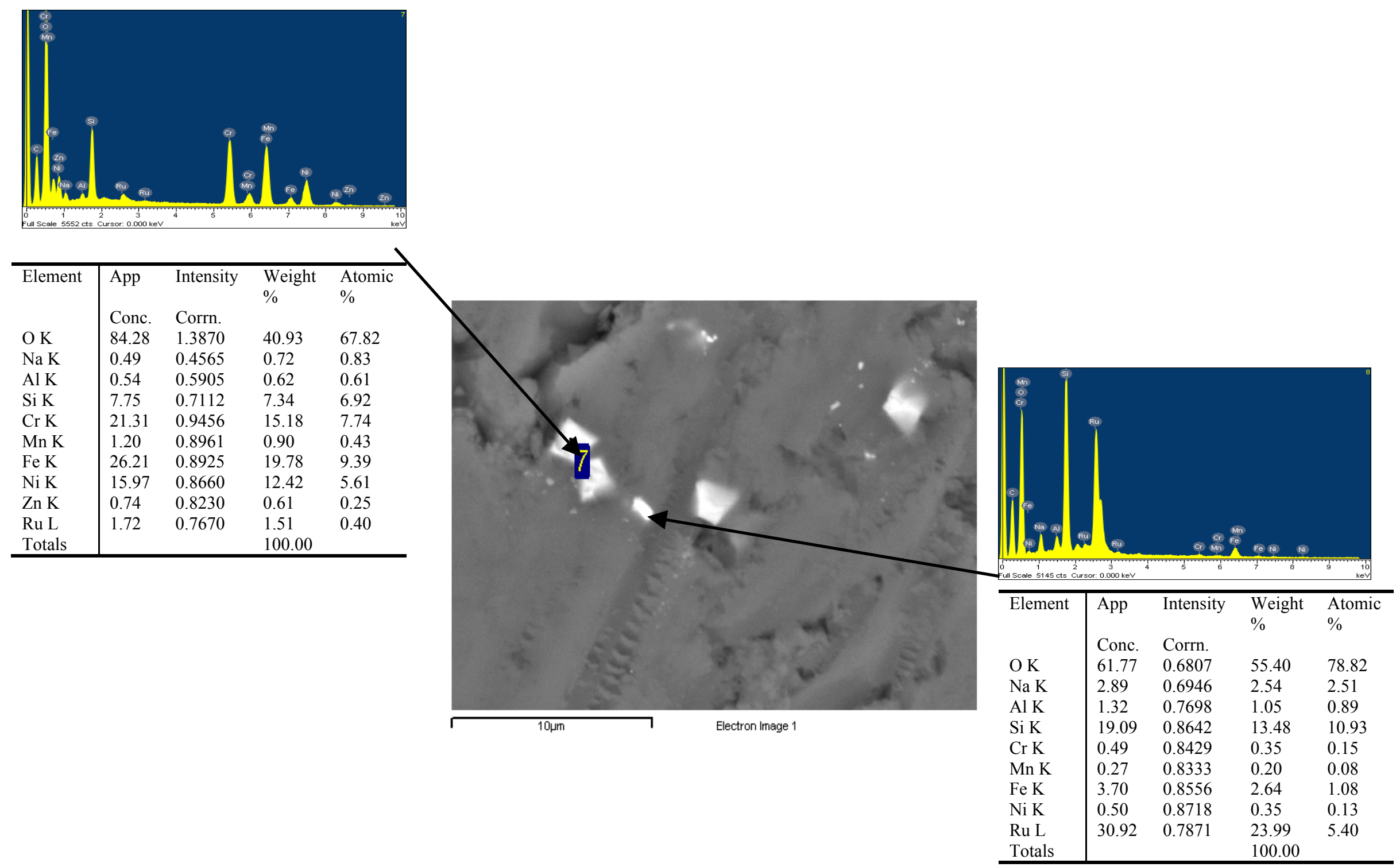

Figure 4-12. $0.5 \% \mathrm{NiCr}_{2} \mathrm{O}_{4}$ in Modifed $\mathrm{NCAW}\left(950^{\circ} \mathrm{C} / 23 \mathrm{~h}\right)$ - Different Region 


\subsection{Crystallization Studies}

XRD was used to compare the effect of $\mathrm{RuO}_{2}$ and $\mathrm{WO}_{3}$ on crystals formed in the MS-7 glass melt. Figures 4.13 and 4.14 showed that $\mathrm{RuO}_{2}$ as well as $\mathrm{WO}_{3}$ formed mainly spinel (Trevorite $-\mathrm{NiFe}_{2} \mathrm{O}_{4}$ ) crystals under comparable test conditions $\left(0.5 \mathrm{wt} . \%, 1000^{\circ} \mathrm{C}\right)$. Undissolved $\mathrm{RuO}_{2}$ was detected. No other prominent phase could be detected within the detectability of the XRD technique. Further investigation of effects of temperature $\left(950^{\circ} \mathrm{C}\right.$ ) and time (Figure 4.15) on the crystallization confirmed formation of various amounts of Trevorite. These results indicated that $\mathrm{WO}_{3}$ addition did not crystallize any new phase in the test melt.

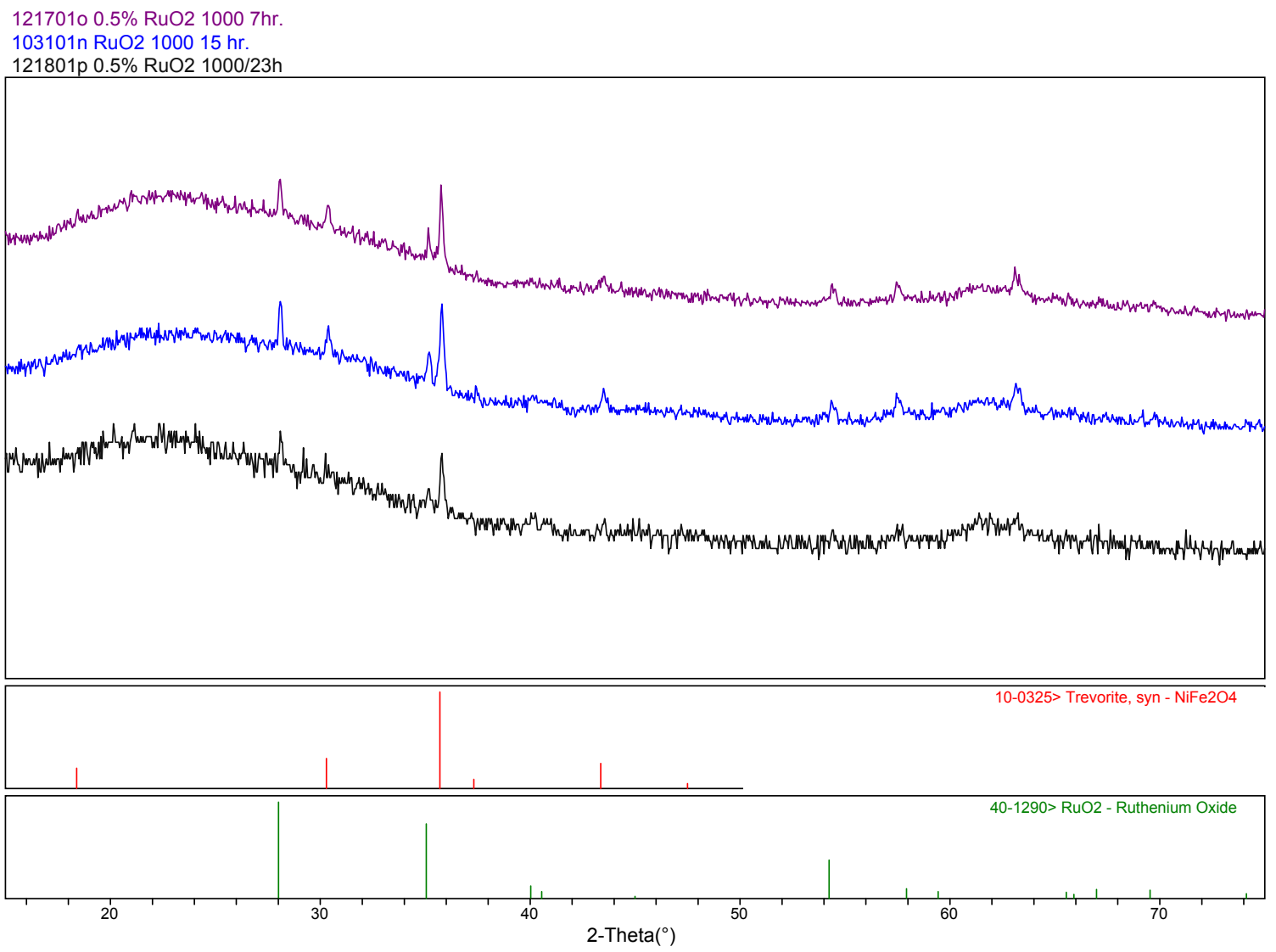

Figure 4-13. XRD of $\mathrm{RuO}_{2}$ in $\mathrm{MS}-7\left(0.5 \mathrm{wt} \%, \mathbf{1 0 0 0}^{\circ} \mathrm{C}\right)$ 

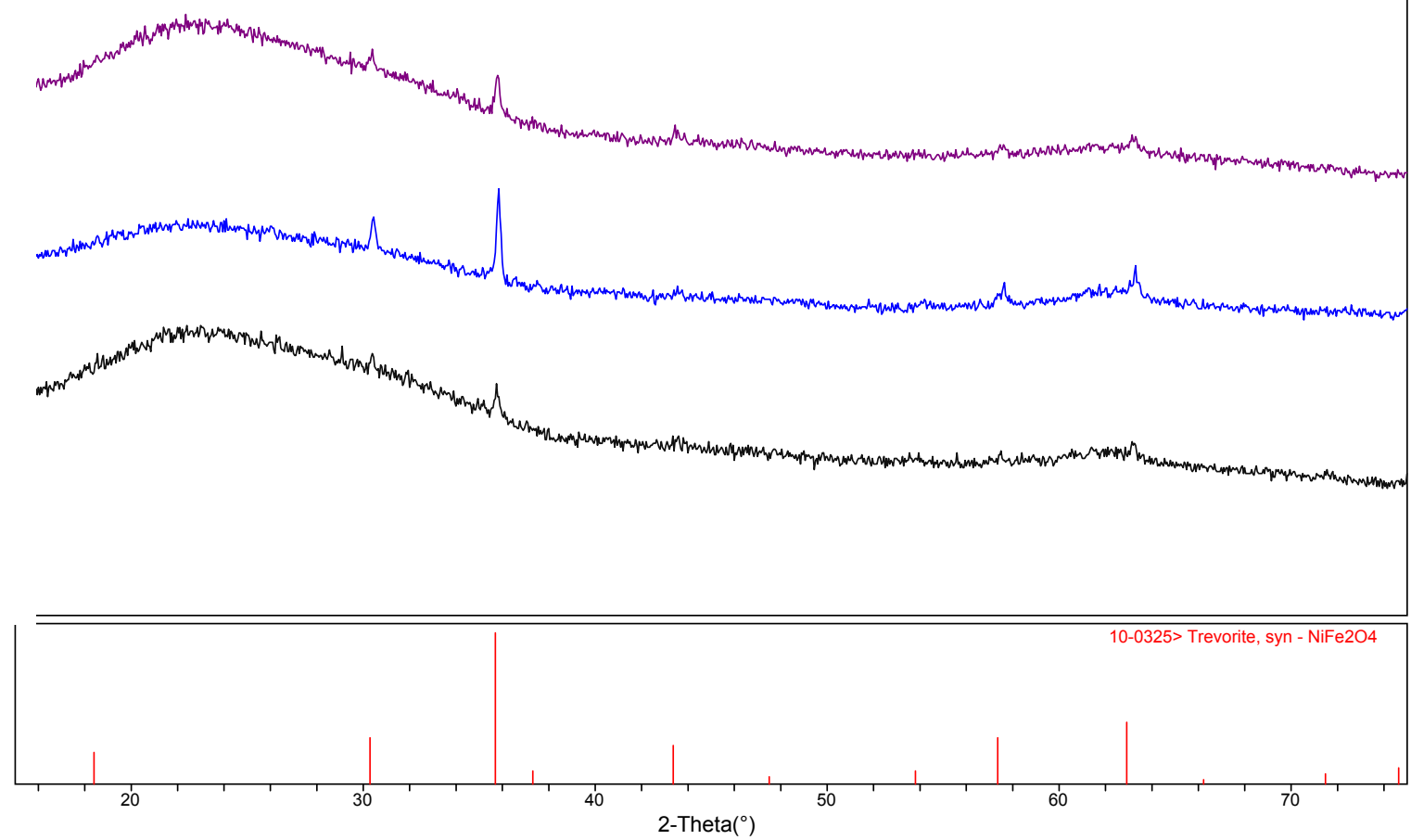

Figure 4-14. XRD of $\mathrm{WO}_{3}$ in $\mathrm{MS}-7\left(0.5 \mathrm{wt} \%, \mathbf{1 0 0 0}^{\circ} \mathrm{C}\right)$ 

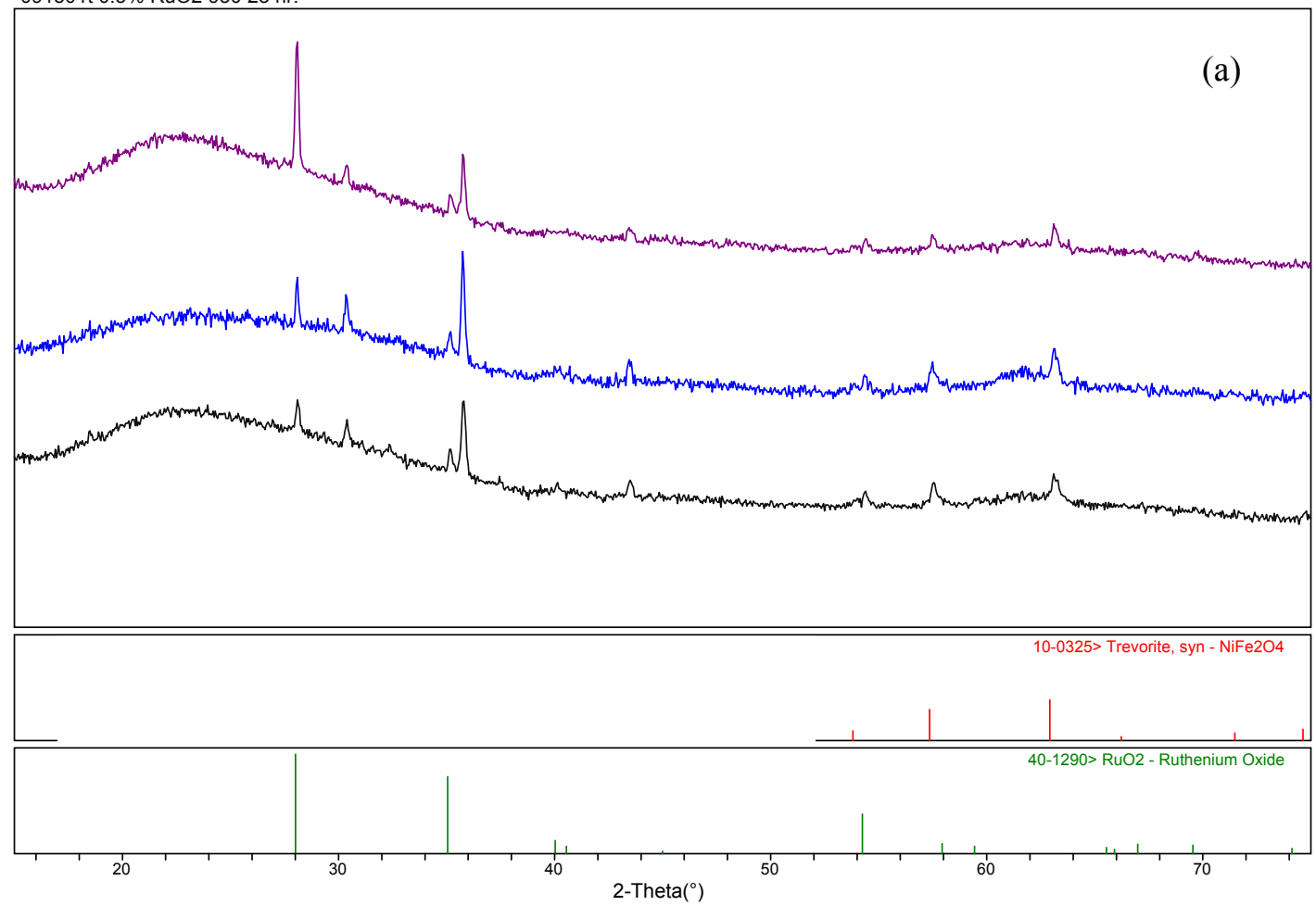

$091001 \mathrm{n} \mathrm{0.5 \%} \mathrm{WO3} 95023 \mathrm{hr}$

$090401 \mathrm{n} 0.5 \%$ WO3 $95015 \mathrm{hr}$

$090501 \mathrm{n} 0.5 \%$ WO3 $9507 \mathrm{hr}$.

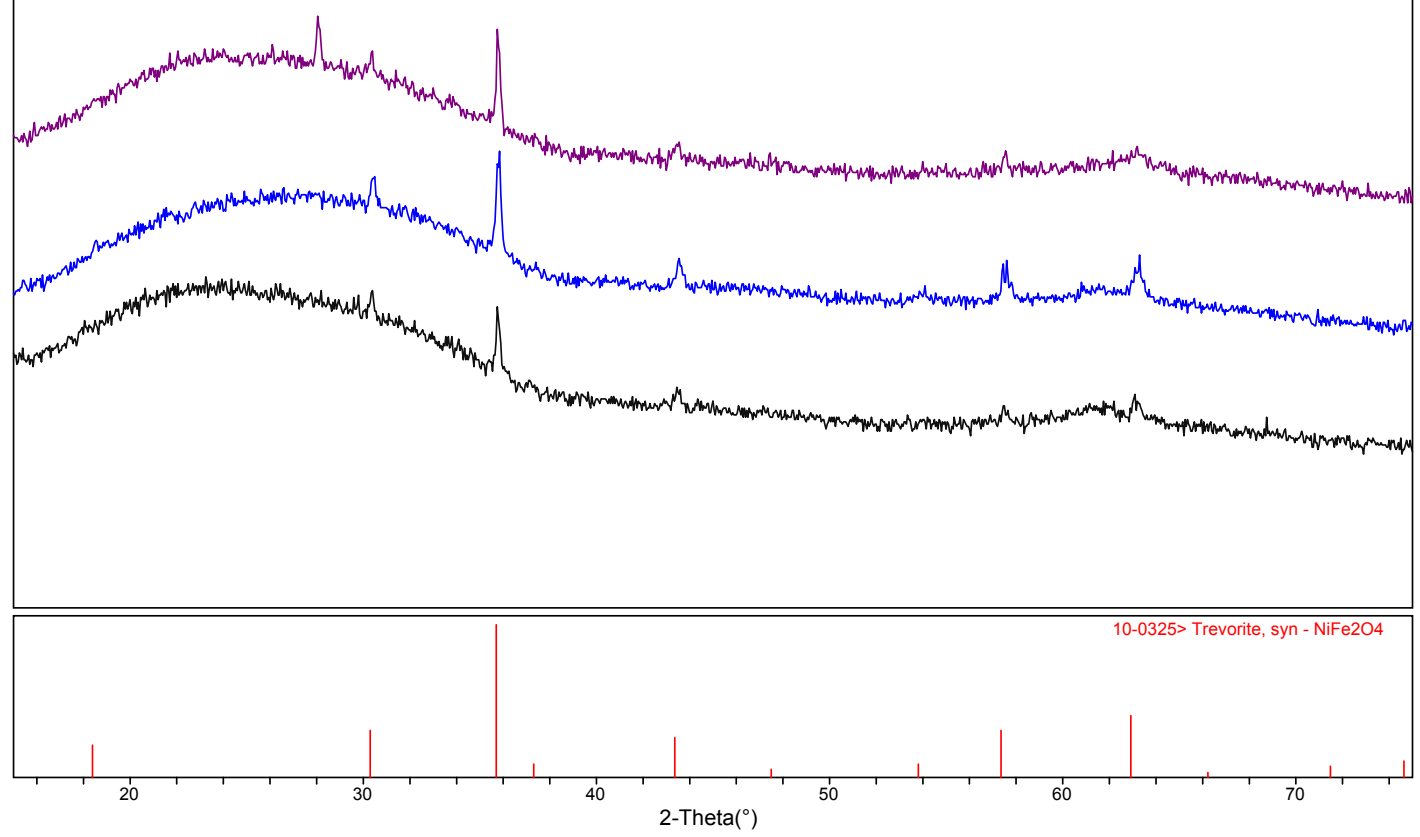

Figure 4-15. $\mathrm{XRD}$ of a) $\mathrm{RuO}_{2}$ and b) $\mathrm{WO}_{3}\left(\mathrm{MS}-7,0.5 \mathrm{wt} \%\right.$, $950^{\circ} \mathrm{C}$ ) 


\subsection{Viscosity}

Gradual addition of $\mathrm{NiCr}_{2} \mathrm{O}_{4}$ to modified would increase the spinel that crystallized from the melt, consequently increasing the viscosity of the melt. This is demonstrated in this section. Figure 4.16 shows the temperature dependence of the base modified NCAW glass. The viscosity values ranged from 1.8 $\mathrm{Pa} \cdot \mathrm{s}$ at $1356^{\circ} \mathrm{C}$ to $17.3 \mathrm{~Pa} \cdot \mathrm{s}$ at $1051^{\circ} \mathrm{C}$. On addition of $1 \mathrm{wt} . \%$ of $\mathrm{NiCr}_{2} \mathrm{O}_{4}$ (Figure 4.17), the viscosity values increased slightly to $3.1 \mathrm{~Pa} \cdot \mathrm{s}$ at $1247^{\circ} \mathrm{C}$ and to $58.6 \mathrm{~Pa} \cdot \mathrm{s}$ at $953^{\circ} \mathrm{C}$. On further addition $(10 \mathrm{wt} . \%$ of $\mathrm{NiCr}_{2} \mathrm{O}_{4}$ ), the viscosity values increased significantly to $47.4 \mathrm{~Pa} \cdot \mathrm{s}$ at $1351^{\circ} \mathrm{C}$ and to $209.8 \mathrm{~Pa} \cdot \mathrm{s}$ at $1050^{\circ} \mathrm{C}$. At about $1050^{\circ} \mathrm{C}$, the viscosity values were $17.3,18.2$, and $209.8 \mathrm{~Pa} \cdot \mathrm{s}$ for the base modified NCAW glass, the modified NCAW glass with 1 wt. $\% \mathrm{NiCr}_{2} \mathrm{O}_{4}$, and the modified NCAW glass with $10 \mathrm{wt} . \% \mathrm{NiCr}_{2} \mathrm{O}_{4}$, respectively.

Figure 4.19 shows the rheology of the modified NCAW glass with $10 \mathrm{wt} . \% \mathrm{NiCr}_{2} \mathrm{O}_{4}$. Shear stress (Figure 4.19 (a)) corresponds to viscosity values (Figure 4.19(b)). Temperature schedule is shown for comparison. At $1350^{\circ} \mathrm{C}$, the shear stress was $10 \mathrm{~Pa}$ that decreased slightly to $9 \mathrm{~Pa}$ at $1250^{\circ} \mathrm{C}$. Then the shear stress increased to $11 \mathrm{~Pa}$ at $1150^{\circ} \mathrm{C}$ and $12 \mathrm{~Pa}$ at $1050^{\circ} \mathrm{C}$. The increase in shear stress was attributed to the precipitation and settling of the spinel phase.

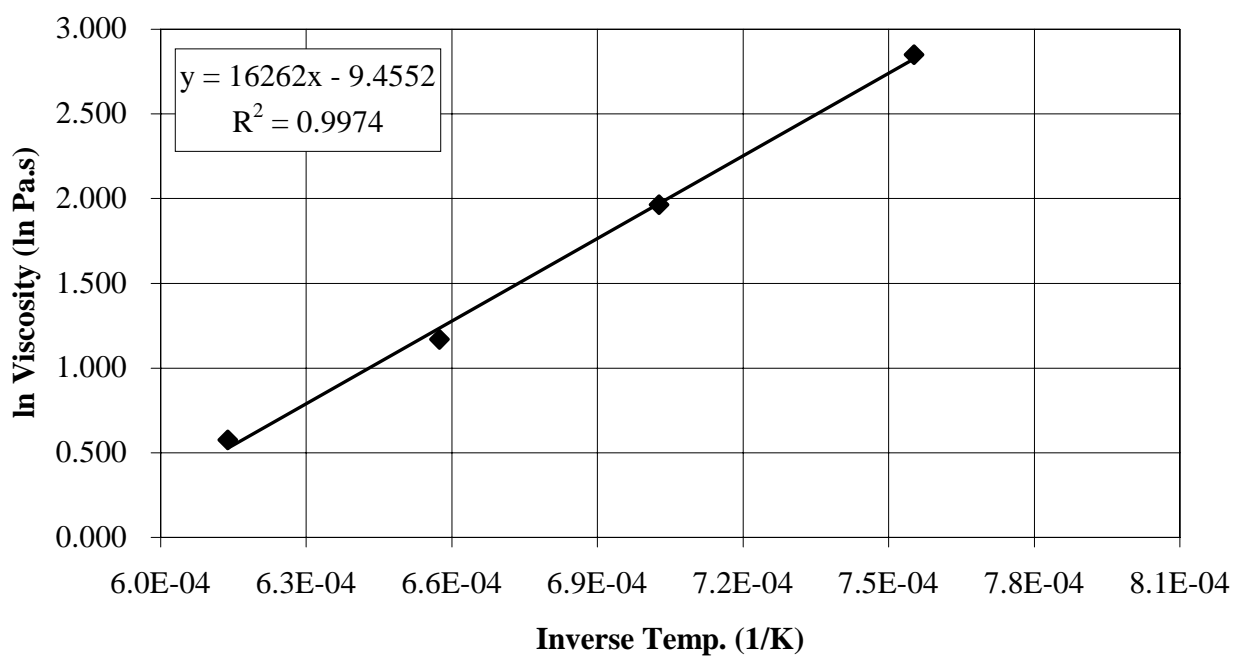

Figure 4-16. Temperature Dependence of Viscosity of Modified NCAW 


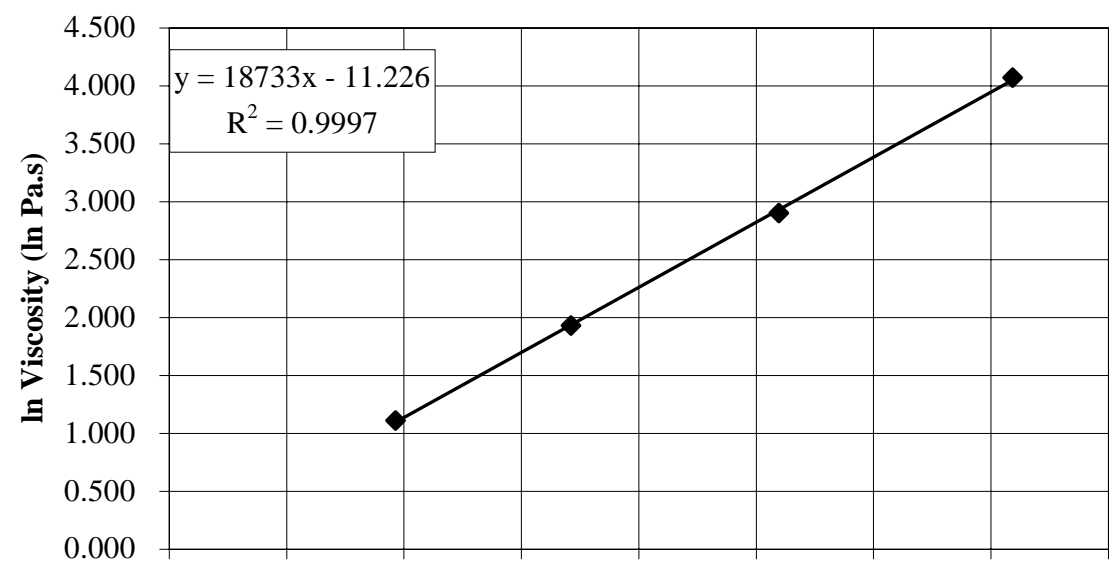

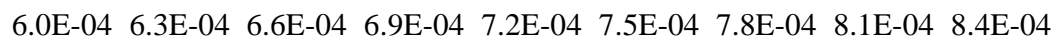

Inverse Temp. (1/K)

Figure 4-17. Temperature Dependence of Viscosity of Modified NCAW with 1 wt. $\% \mathrm{NiCr}_{2} \mathrm{O}_{4}$

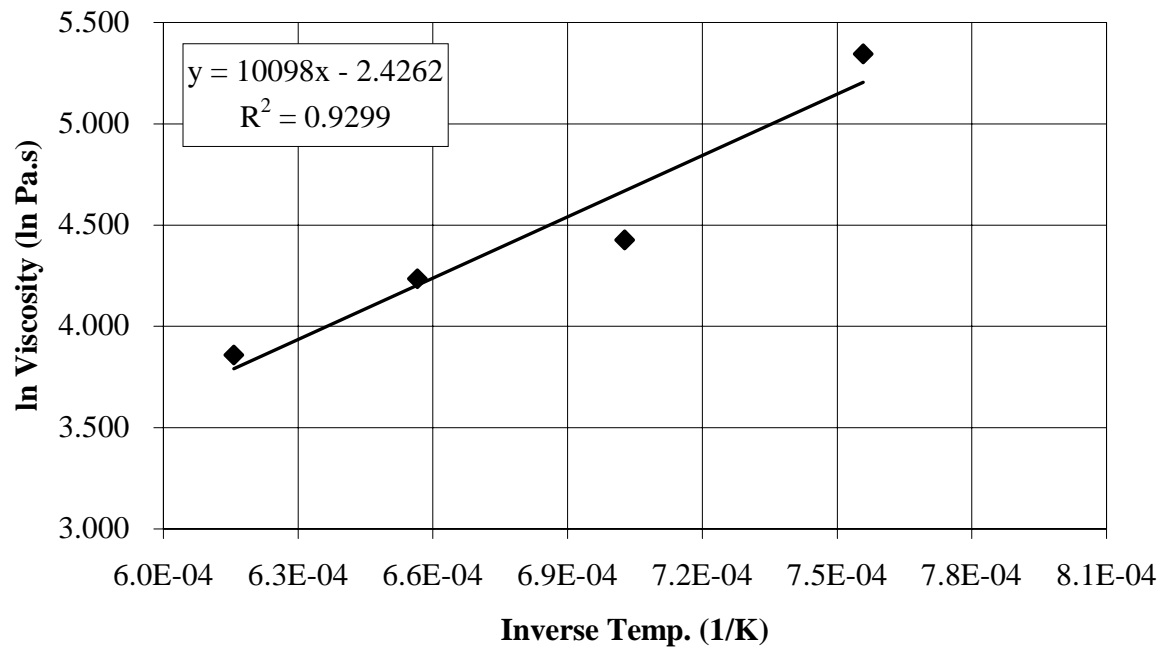

Figure 4-18. Temperature Dependence of Viscosity of Modified NCAW with 10 wt. $\% \mathrm{NiCr}_{2} \mathrm{O}_{4}$ 


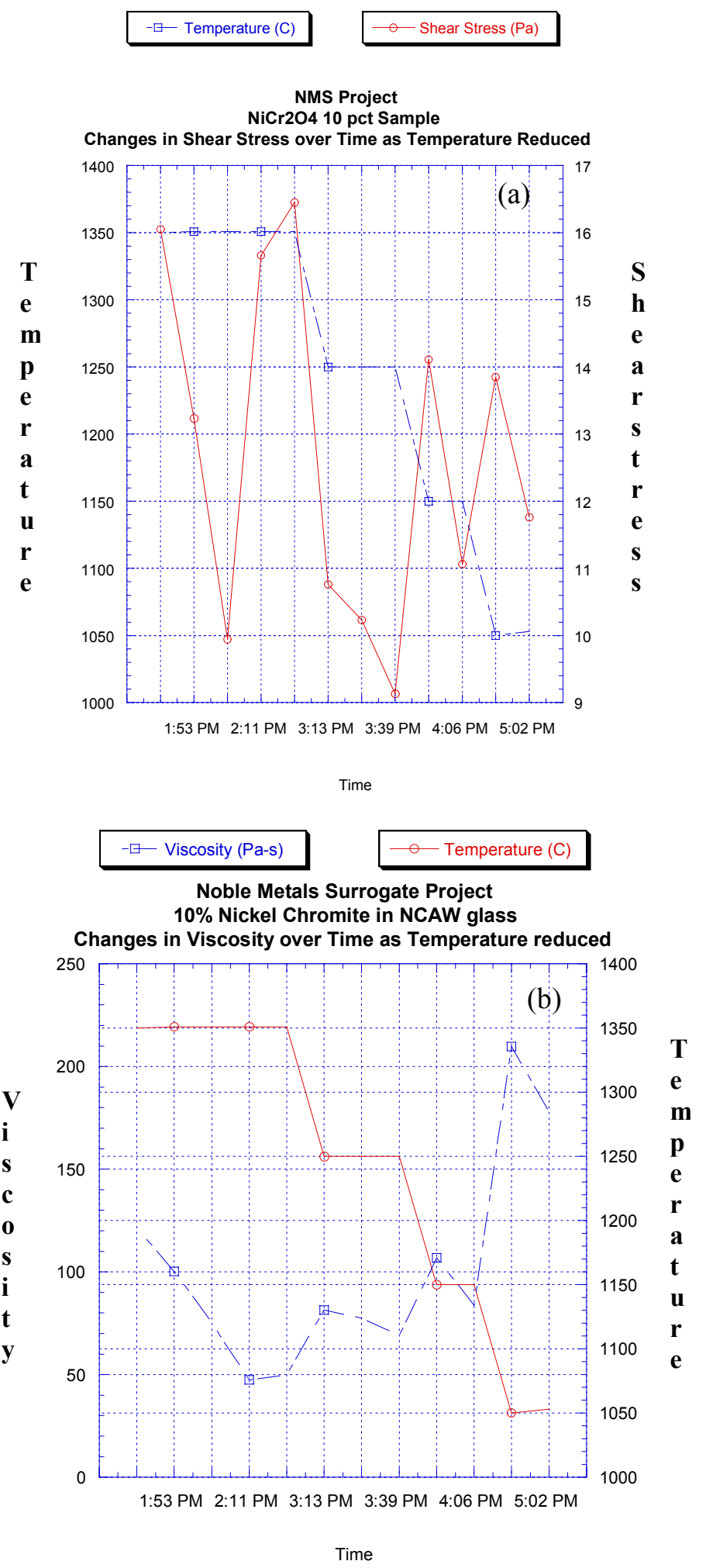

Figure 4-19. (a) Shear Stress and (b) Viscosity of Modified $\mathrm{NCAW}$ with 10 wt.\% $\mathrm{NiCr}_{2} \mathrm{O}_{4}$ 


\subsection{High Temperature Optical Microscopy}

High temperature optical microscopy was used to compare the dissolution and suspension of 1 wt.\% of $\mathrm{RuO}_{2}$ (Figure 4.20) and $\mathrm{NiCr}_{2} \mathrm{O}_{4}$ (Figure 4.21) in MS-7 glass melt. The bright spots were due to reflections of the light from the surface of the melt. The melts showed a lot of activities, that is, moving, turning, bubbling, and convection as the temperature increased. Aggregates of $\mathrm{RuO}_{2}$ seen at $461^{\circ} \mathrm{C}$ in Figure 4.20 incorporated into the melt as the temperature increased. At $994^{\circ} \mathrm{C}$ and beyond, residual fibrous suspensions were seen, indicating undissolved $\mathrm{RuO}_{2}$ floating on the surface. In the case of $\mathrm{NiCr}_{2} \mathrm{O}_{4}$, aggregates incorporated into the melt as temperature increased. At $1078^{\circ} \mathrm{C}$, no suspension was seen, indicating solubility of $\mathrm{NiCr}_{2} \mathrm{O}_{4}$ in the melt. These observations also supported the observations of the double-crucible study (section 4.1).

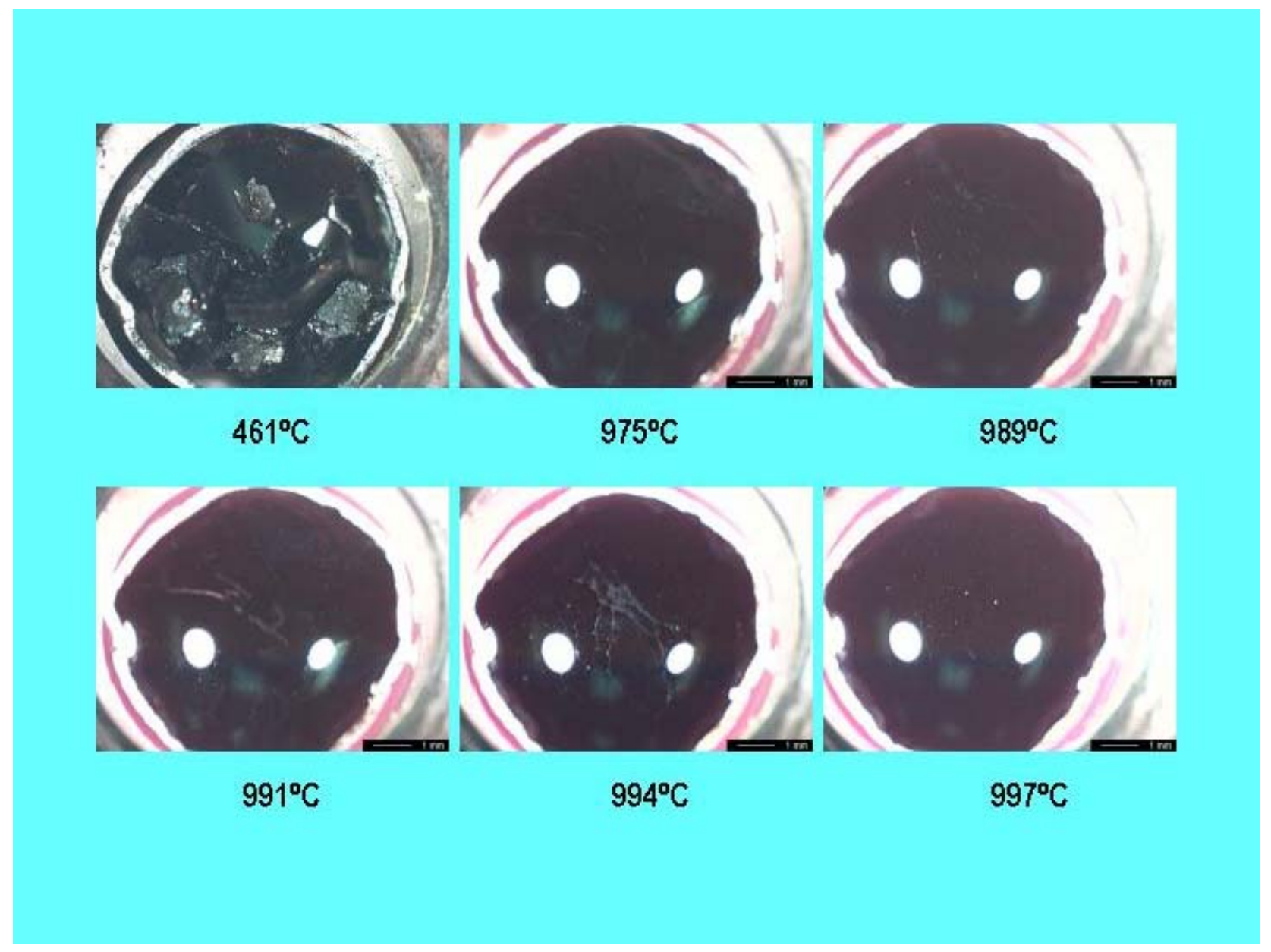

Figure 4-20. High Temperature Optical Micrographs (1 wt.\% $\mathrm{RuO}_{2}$ in MS-7) 


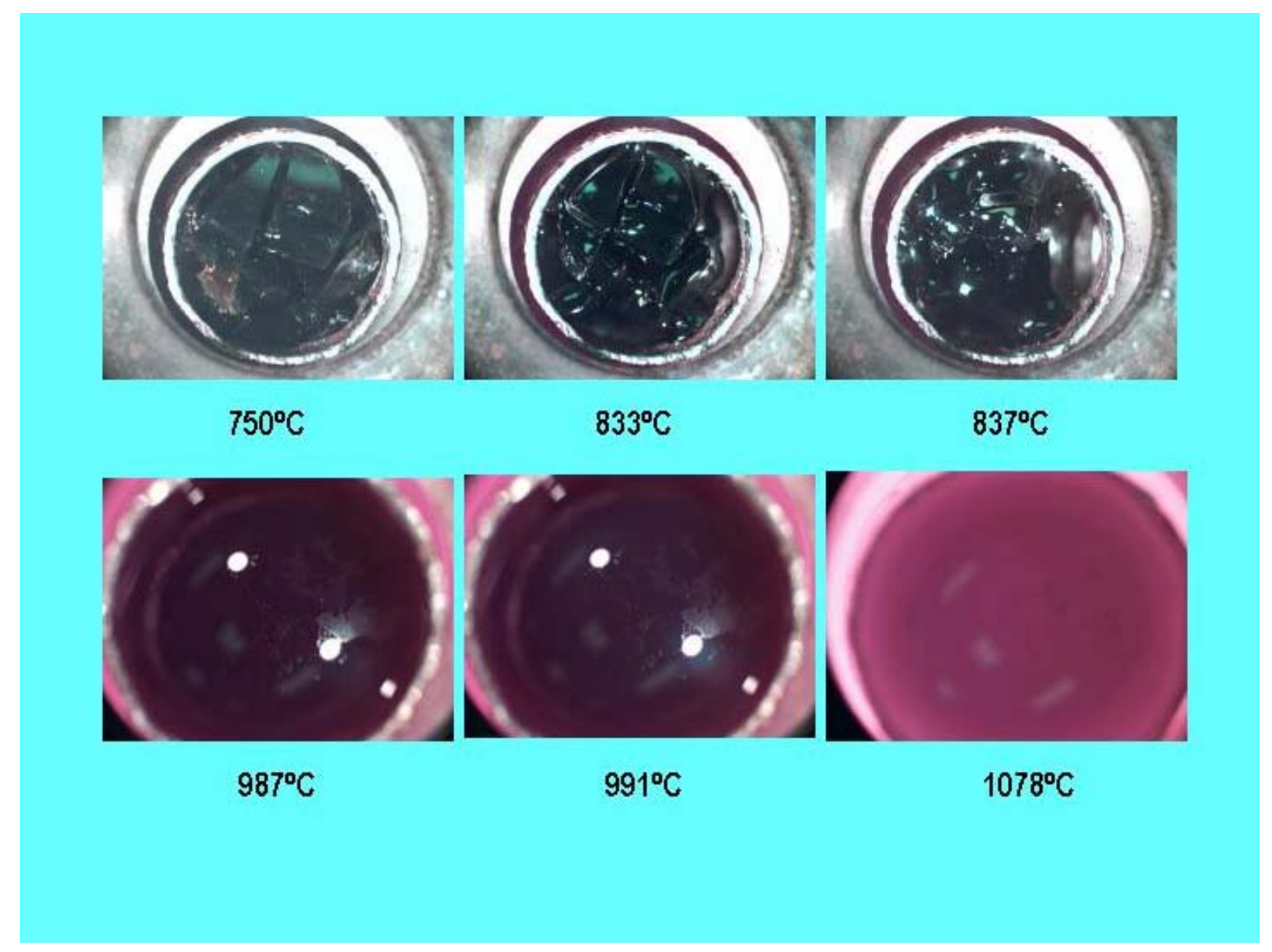

Figure 4-21. High Temperature Optical Micrographs (1 wt.\% $\mathrm{NiCr}_{2} \mathrm{O}_{4}$ in $\mathrm{MS}-7$ ) 


\subsection{Partition Studies}

All partition studies used $0.5 \mathrm{wt} \% \%$ of $\mathrm{Ru}, \mathrm{RuO}_{2}, \mathrm{~W}$, or $\mathrm{WO}_{3}$. All the SEM images shown in this section (Figure 4.22 - 4.31) as well as in Appendix A (Figures A.1-A.20) are back-scattered images. In these figures, the line scans are shown on the SEM images as well as separately for clarity and comparison.

\subsubsection{Ru vs. $\mathrm{RuO} \mathrm{O}_{2}$}

Figures 4.22 and 4.23 compare the addition of $\mathrm{Ru}$ and $\mathrm{RuO}_{2}$ under identical test conditions $\left(900^{\circ} \mathrm{C} / 7 \mathrm{~h}\right)$, respectively. In the case of $\mathrm{Ru}$ (Figure 4.22$)$, an interfacial reaction layer of about 10-20 $\mu \mathrm{m}$ thickness containing Ru and spinel components $(\mathrm{Al}, \mathrm{Mg})$ was observed at the spinel-glass interface. $\mathrm{Ru}$ particulates crowded the glass side of this interface over $100 \mu \mathrm{m}$. Near the reaction layer, dislodged spinel segments were seen. In the case of $\mathrm{RuO}_{2}$ (Figure 4.23), the reaction layer was about 5-15 $\mu \mathrm{m}$. On the glass side of the interface, several dislodged spinel segments drifting well into the glass was seen. Rucontaining clusters were also seen in the glass side of the interfacial region.

\subsubsection{Wvs. $\mathrm{WO}_{3}$}

Figures 4.24 and 25 compare the addition of $\mathrm{W}$ and $\mathrm{WO}_{3}$ under identical test conditions $\left(900^{\circ} \mathrm{C} / 7 \mathrm{~h}\right)$, respectively. In the case of W (Figure 4.24), an interfacial reaction layer of about 10-15 $\mu \mathrm{m}$ thickness containing $\mathrm{W}$ and spinel components was observed at the spinel-glass interface. On the glass side of the interface, several dislodged spinel segments drifting into the glass was seen. A few Wcontaining particulates were also observed. In the case of $\mathrm{WO}_{3}$ (Figure 4.25), the interfacial layer was thicker $(20-30 \mu \mathrm{m})$ with no dislodged spinel segments in the interfacial region.

\subsubsection{Effect of Temperature of Testing}

On increasing the test temperature from 900 to $1000^{\circ} \mathrm{C}$ for $7 \mathrm{~h}$ of exposure, the thickness of the interfacial reaction layer remained more or less same in the sample containing $\mathrm{RuO}_{2}$ (Figure 26 vs. Figure 27). At $1000^{\circ} \mathrm{C}$, the dislodged spinel segments dissolved into the glass melt. Ru-containing particulates were observed in the interfacial regions. Recrystallization of spinel (sharp edges of crystals in the glass side in Figure 4.27) was observed at $1000^{\circ} \mathrm{C}$.

In the case of $\mathrm{WO}_{3}$, increase of test temperature from 900 to $1000^{\circ} \mathrm{C}$ for $7 \mathrm{~h}$ exposure (Figure 4.28 vs. Figure 4.29 ) resulted in a slightly thinner interfacial reaction layer. At $1000^{\circ} \mathrm{C}$, the spinel started dislodging and drifting into the glass side of the interfacial region. Other features remained the same.

\subsubsection{Effect of Duration of Testing}

On increasing the duration of the testing from $7 \mathrm{~h}$ to $23 \mathrm{~h}, \mathrm{RuO}_{2}$ showed the interfacial layer of more or less same thickness of about 5-15 $\mu \mathrm{m}$, containing Ru- and spinel components (Figure 4.30). For extended period of exposures (after 19h), spinel dislodging and drifting into the glass melt was observed. $\mathrm{Ru}$-rich clusters were seen in the glass side of the interfacial region.

In the case of $\mathrm{WO}_{3}$, the reaction layer gradually thickened with increasing exposure time (Figure 4.31). Cracks along the interfacial reaction layer for $19 \mathrm{~h}$ and $23 \mathrm{~h}$ exposures indicated removal of the thick reaction layer due to difference in thermal expansion characteristics of the layer compared to the spinel and glass that resulted in interfacial stresses. Small segments of spinel continued to dissolve in to the glass. Recrystallization of large spinel crystals was observed for $23 \mathrm{~h}$ exposure. 


\subsubsection{Partition $-\mathrm{RuO}_{2}$ vs. $\mathrm{WO}_{3}$}

The results presented in this section (Figures 4.22 - 4.31) and the Appendix A (Figures A.1 A.20) revealed the similarities and differences between $\mathrm{RuO}_{2}$ and $\mathrm{WO}_{3}$. The similarities were:

- The glass melt reacted with the spinel forming a reaction layer at the spinel-glass interfacial region. $\mathrm{Ru}$ or $\mathrm{W}$ partitioned in spinel in this reaction layer.

- Dislodged spinel segments from the bulk spinel eventually dissolved into the glass melt.

- $\mathrm{Ru}$-containing and $\mathrm{W}$-rich regions were observed in the glass side of the interfacial region.

- Spinel (either $\mathrm{MgAl}_{2} \mathrm{O}_{4}$ or Trevorite or a combination of these two) recrystallized in the glass melt.

The differences were:

- Spinel segments started dislodging from the bulk and drifting into the glass melt early in the process with $\mathrm{WO}_{3}$.

- The reaction layer thickened with duration of testing in the case of $\mathrm{WO}_{3}$. Interfacial cracks indicated stresses introduced by the thickening reaction layer at the spinel-glass interfacial region.

- In the case of $\mathrm{RuO}_{2}$, undissolved $\mathrm{Ru}$-containing particles crowded the interfacial region.

- Bigger spinel crystals (sharp plates as well as nodular) recrystallized from the melt with $\mathrm{WO}_{3}$ as compared to small crystal with $\mathrm{RuO}_{2}$ for identical test conditions.

In spite of these differences, the basic interaction mechanism was found to identical in these cases. These results supported use of $\mathrm{WO}_{3}$ as a suitable surrogate for $\mathrm{RuO}_{2}$ in the test glass melt. 

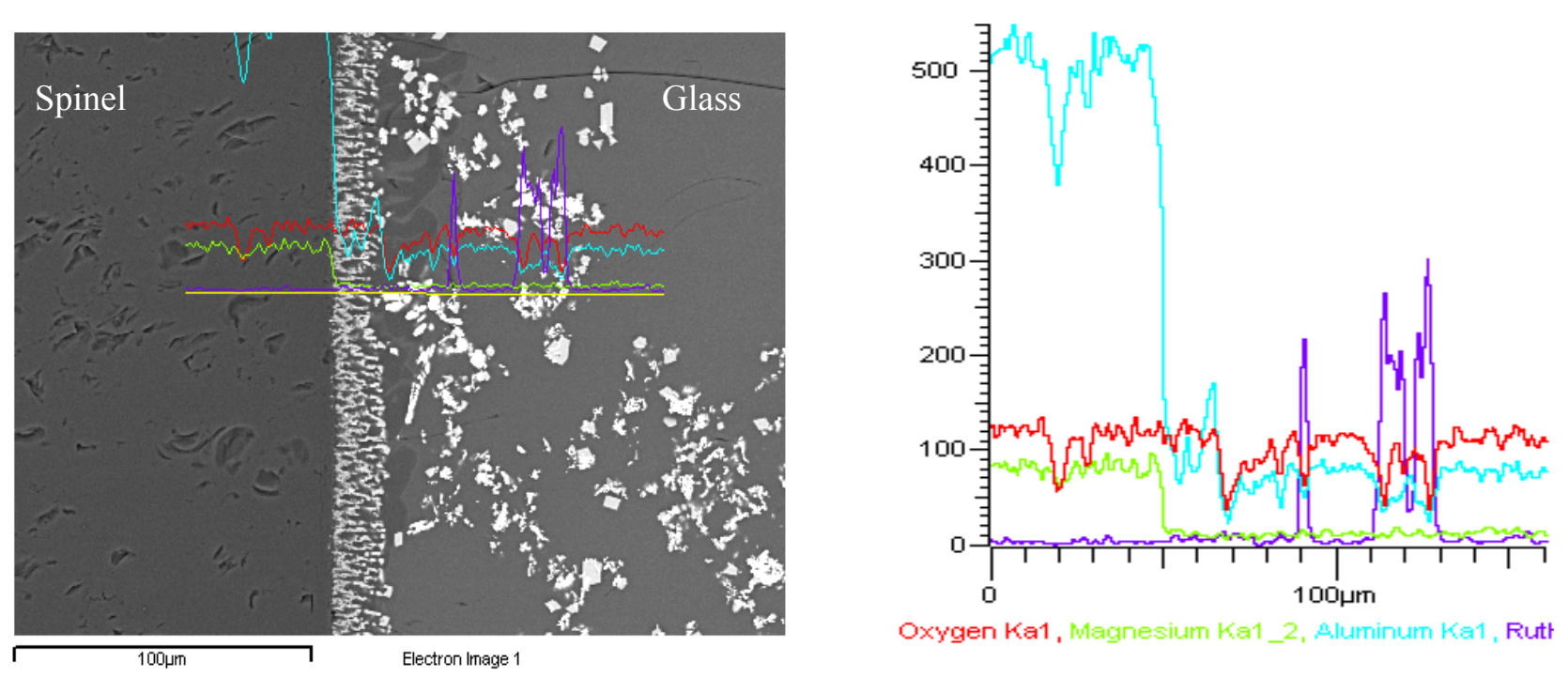

Figure 4-22. SEM (Left) - Line EDS (Right) of Ru in MS-7 $\left(900^{\circ} \mathrm{C} / 7 \mathrm{~h}\right)$
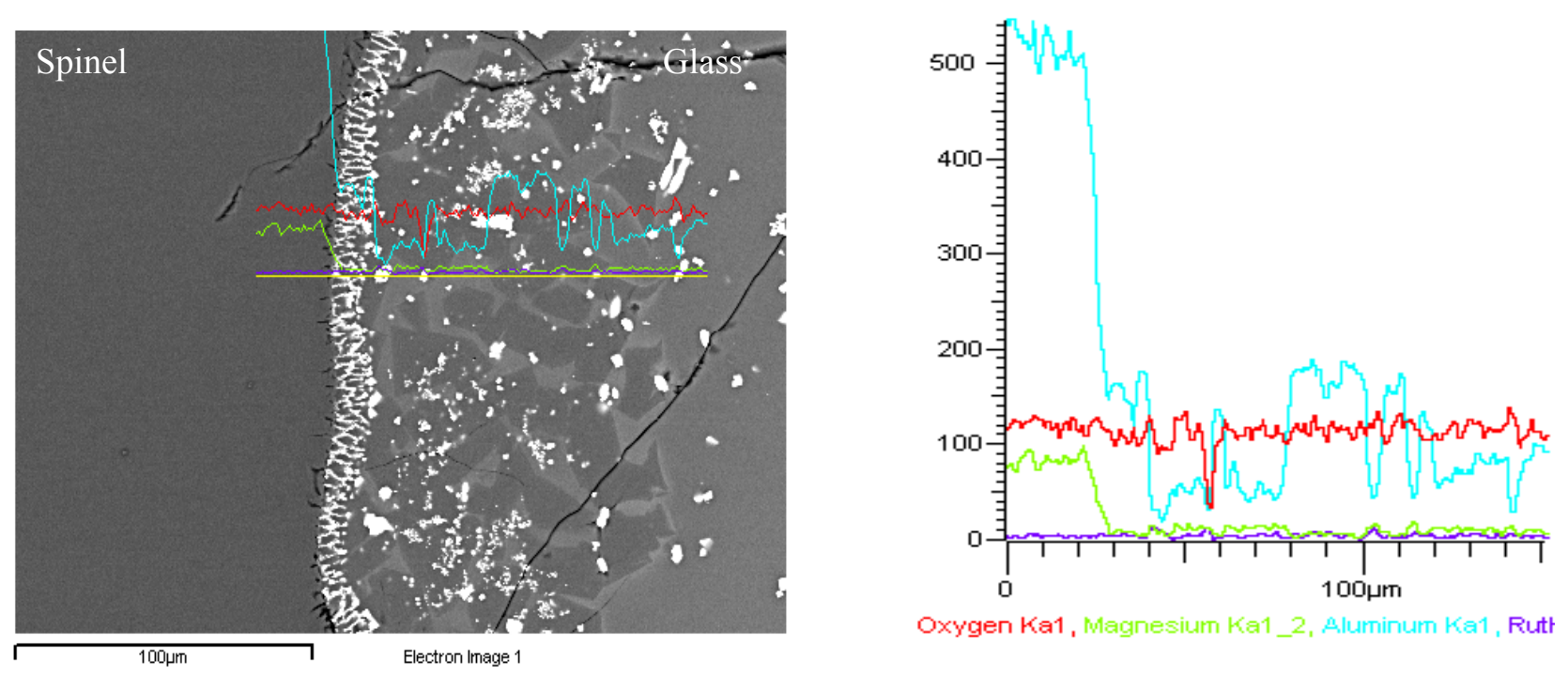

Oxygen Ka1, Magnesium Ka1_2, Aluminum Ka1, Rutr

Figure 4-23. SEM (Left) - Line EDS (Right) of $\mathrm{RuO}_{2}$ in $\mathrm{MS}-7\left(900^{\circ} \mathrm{C} / 7 \mathrm{~h}\right)$ 

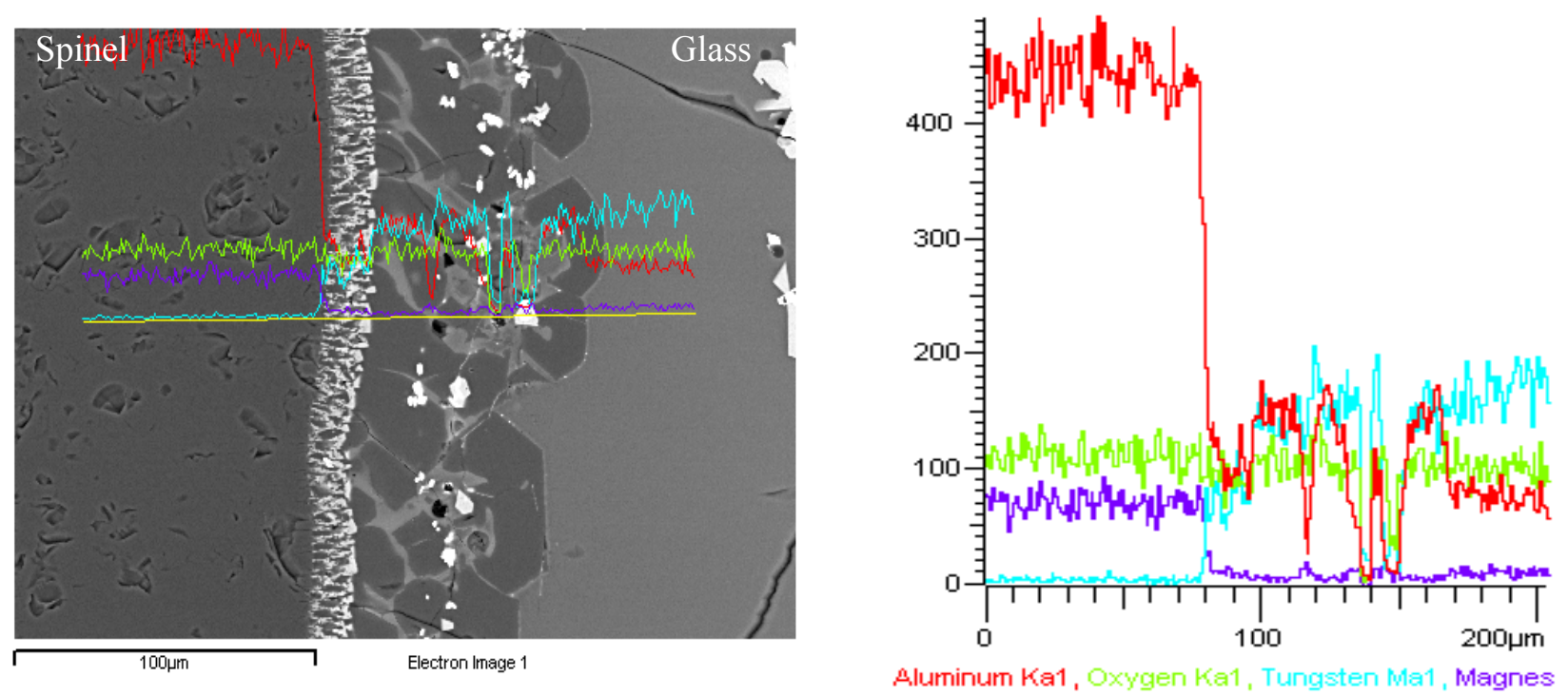

Figure 4-24. SEM (Left) - Line EDS (Right) of W in MS-7 $\left(900^{\circ} \mathrm{C} / 7 \mathrm{~h}\right)$
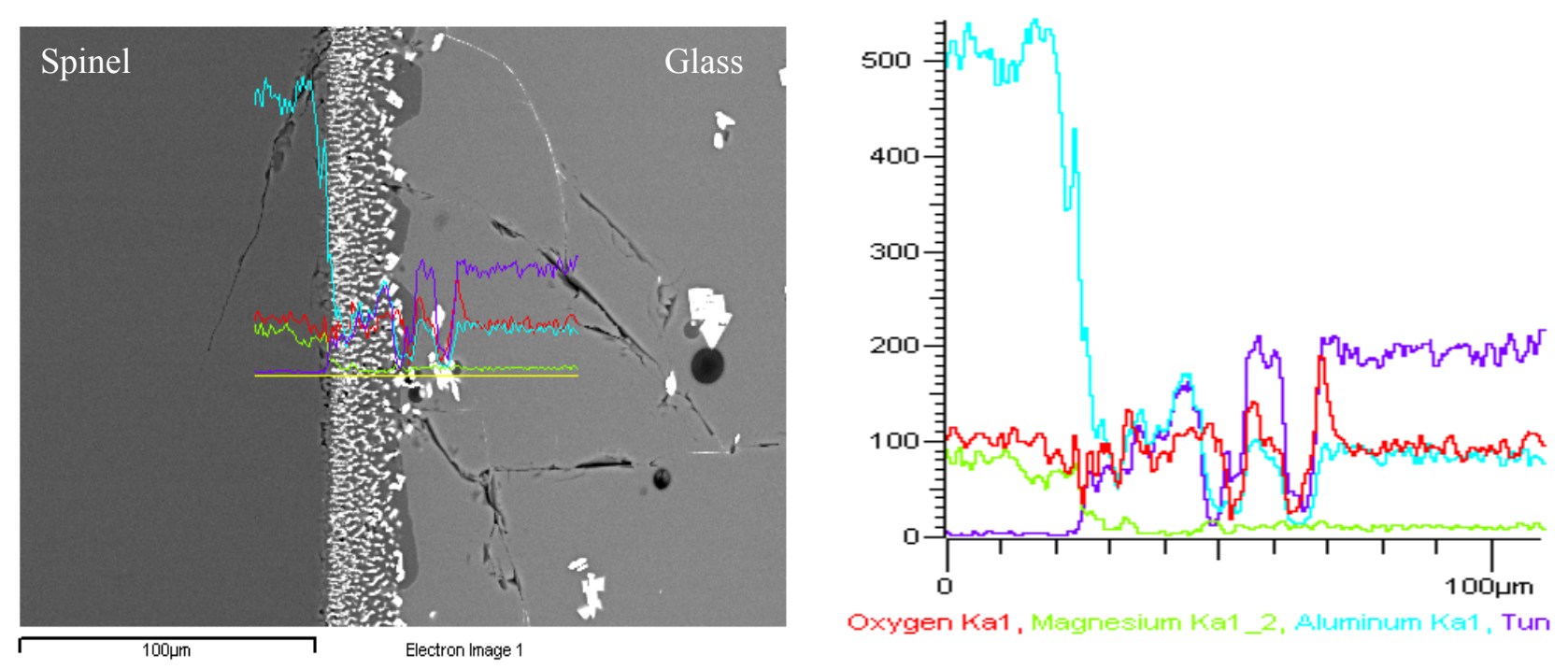

Figure 4-25. SEM (Left) - Line EDS (Right) of $\mathrm{WO}_{3}$ in $\mathrm{MS}-7\left(900^{\circ} \mathrm{C} / 7 \mathrm{~h}\right)$ 

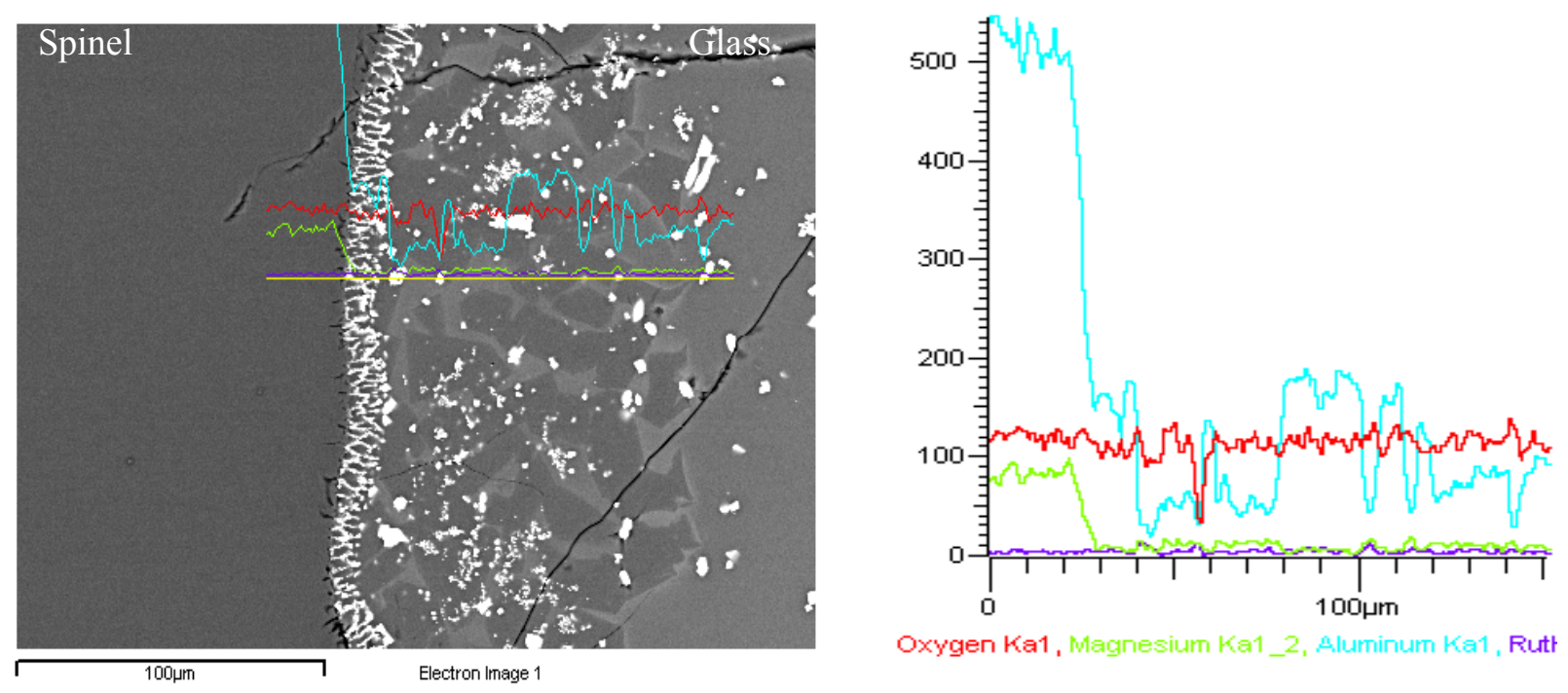

Figure 4-26. SEM (Left) - Line EDS (Right) of $\mathrm{RuO}_{2}$ in $\mathrm{MS}-7\left(900^{\circ} \mathrm{C} / 7 \mathrm{~h}\right)$
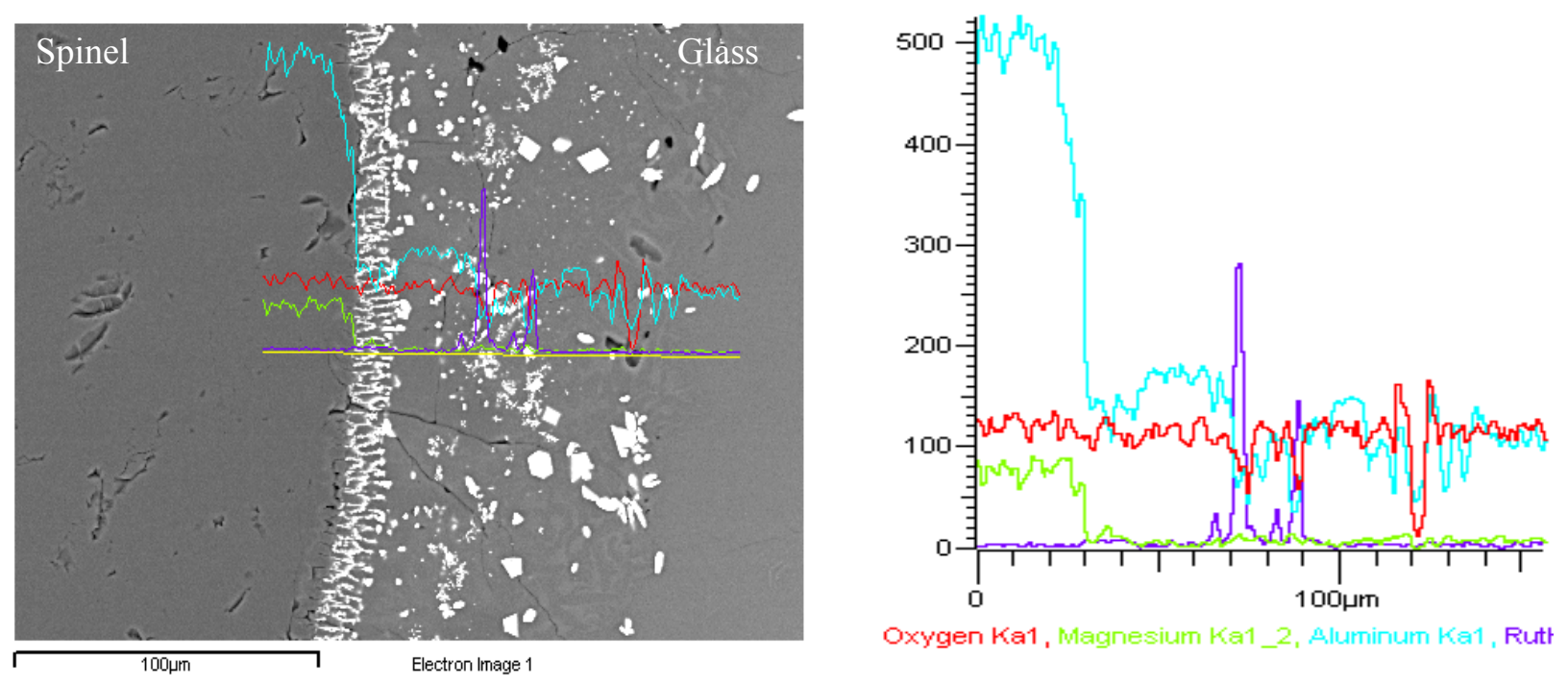

Figure 4-27. SEM (Left) - Line EDS (Right) of $\mathrm{RuO}_{2}$ in $\mathrm{MS}-7\left(1000^{\circ} \mathrm{C} / 7 \mathrm{~h}\right)$ 

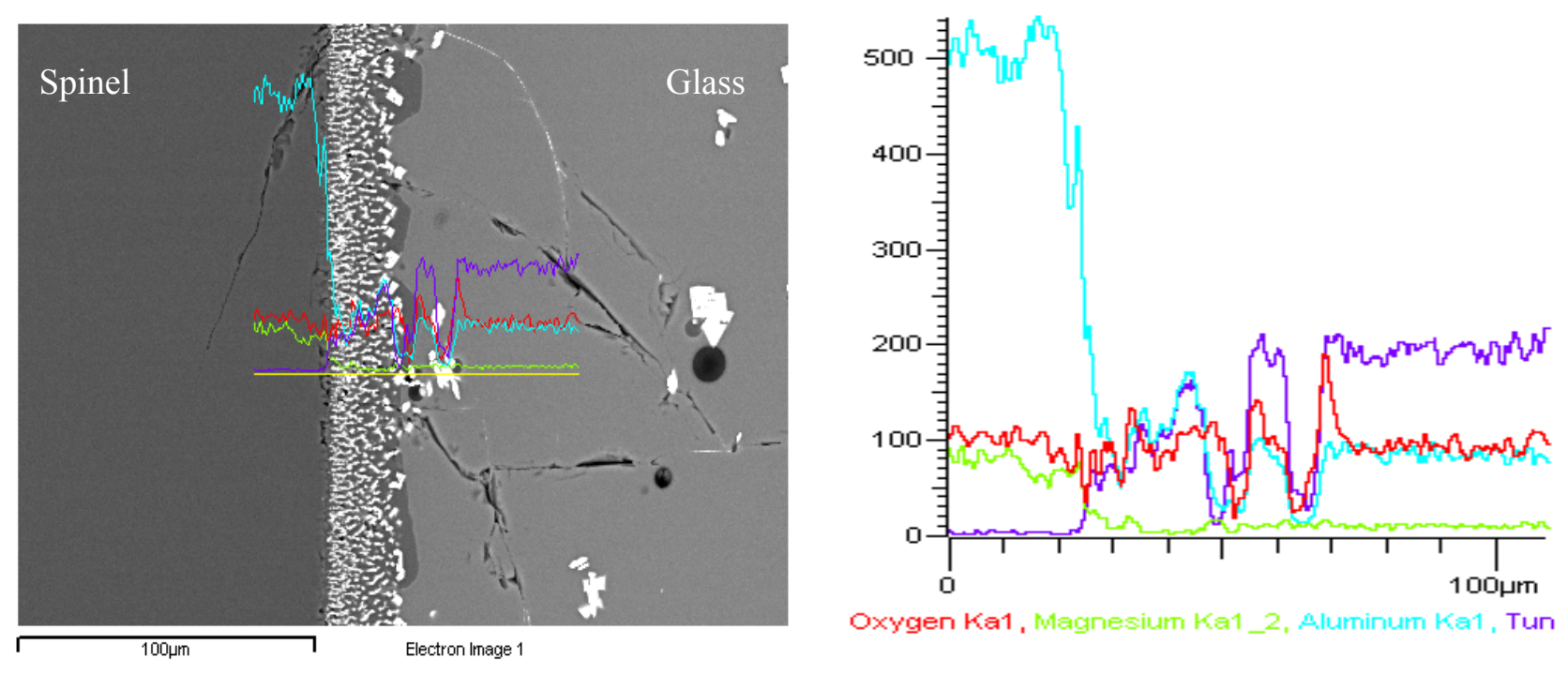

Figure 4-28. SEM (Left) - Line EDS (Right) of $\mathrm{WO}_{3}$ in $\mathrm{MS}-7\left(900^{\circ} \mathrm{C} / 7 \mathrm{~h}\right)$
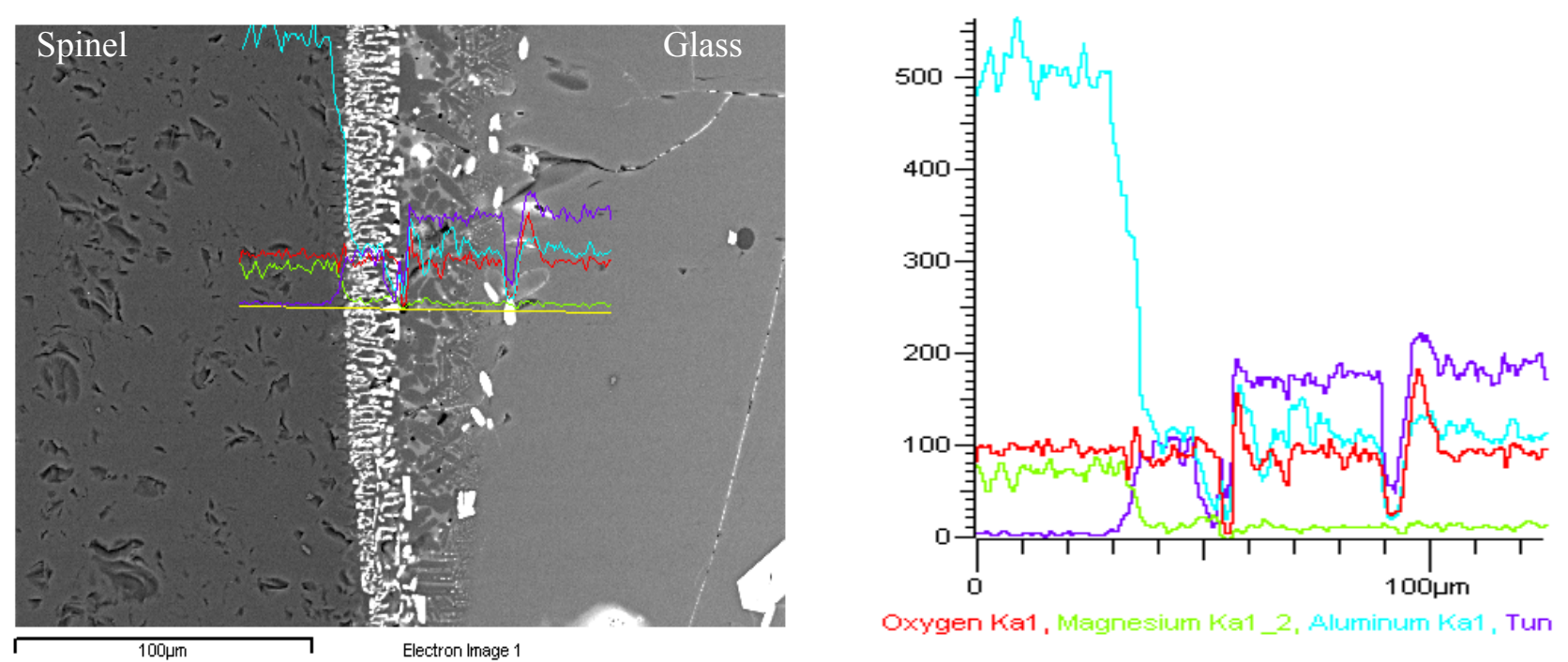

Figure 4-29. SEM (Left) - Line EDS (Right) of $\mathrm{WO}_{3}$ in $\mathrm{MS}-7\left(1000^{\circ} \mathrm{C} / 7 \mathrm{~h}\right)$ 

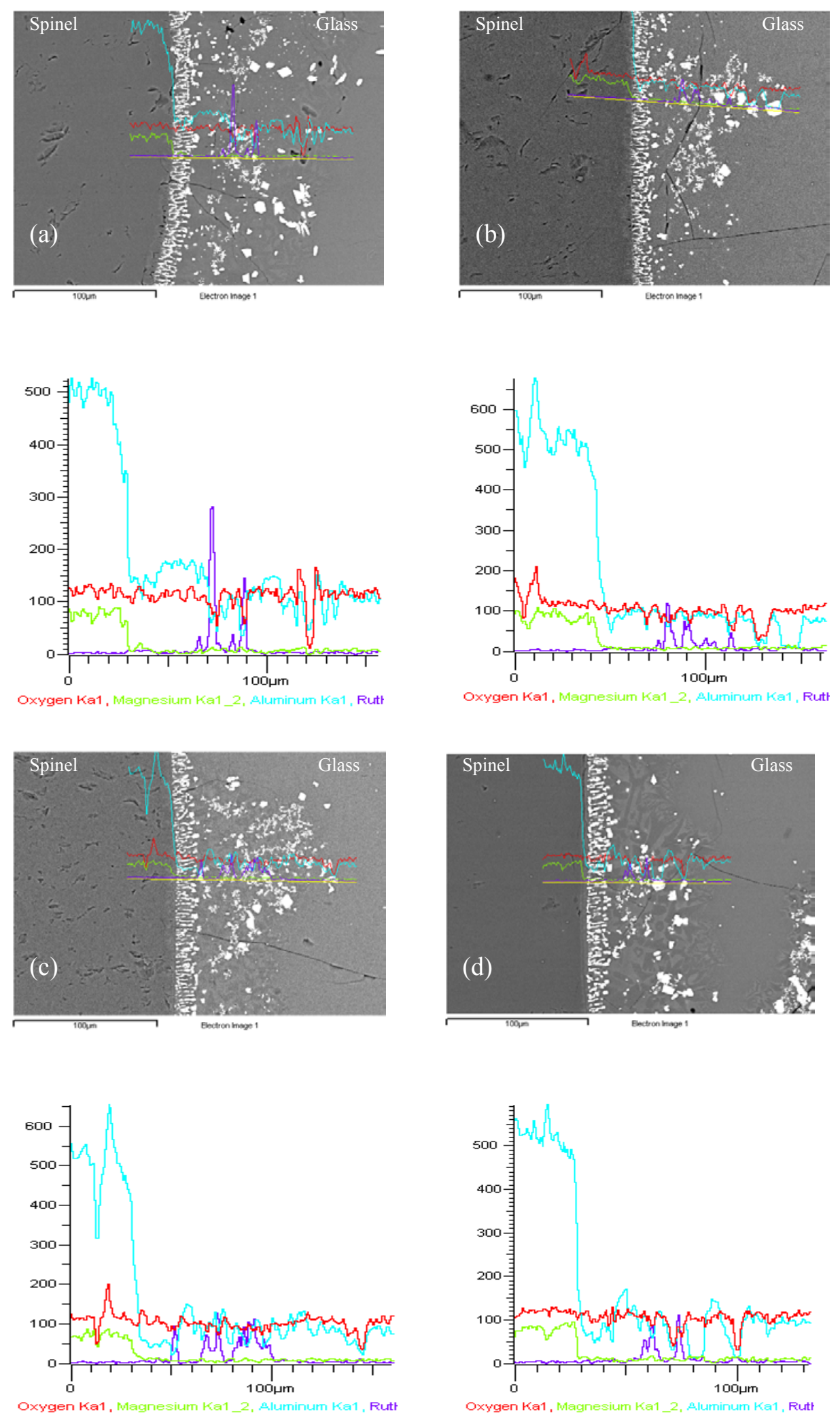

Figure 4-30. SEM (Top) - Line EDS (Bottom) of $\mathrm{RuO}_{2}$ in $\mathrm{MS}-7\left(1000^{\circ} \mathrm{C}\right)$ for (a) $7 \mathrm{~h},(\mathrm{~b}) 15 \mathrm{~h}$, (c) $19 \mathrm{~h}$, and (d) $23 h$ 

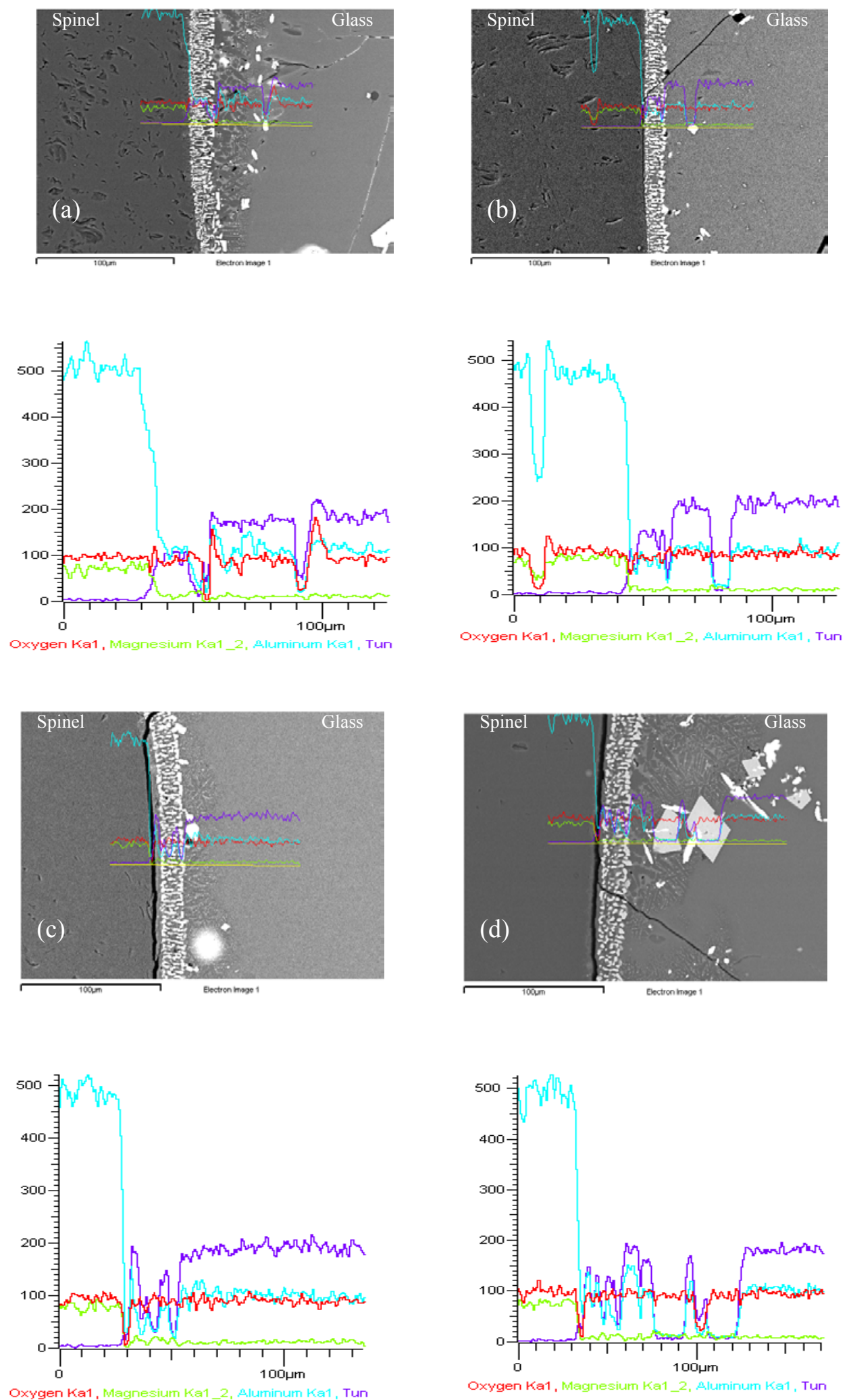

Figure 4-31. SEM (Top) - Line EDS (Bottom) of $\mathrm{WO}_{3}$ in MS-7 $\left(1000^{\circ} \mathrm{C}\right)$ for (a) $7 \mathrm{~h},(\mathrm{~b}) 15 \mathrm{~h}$, (c) $19 \mathrm{~h}$, and (d) $23 \mathrm{~h}$ 


\subsection{AC Conductivity Results}

Figure 4.32 shows the AC conductivity of DWPF frit containing 1-10 wt. \% of Inconel 600 powder, as a conductivity surrogate. Integrated DWPF Melter System (IDMS) data are shown for comparison. IDMS was run for over seven years before shutting down for post mortem analysis. The meltblobs were found at the bottom of the melter, containing significant level of the noble metals as sludge. At lower temperature $\left(950-1050^{\circ} \mathrm{C}\right)$, the conductivity values are comparable to each other $(<100$ $\mathrm{S} / \mathrm{m})$. As the temperature increased, the IDMS showed a sharp increase in conductivity.

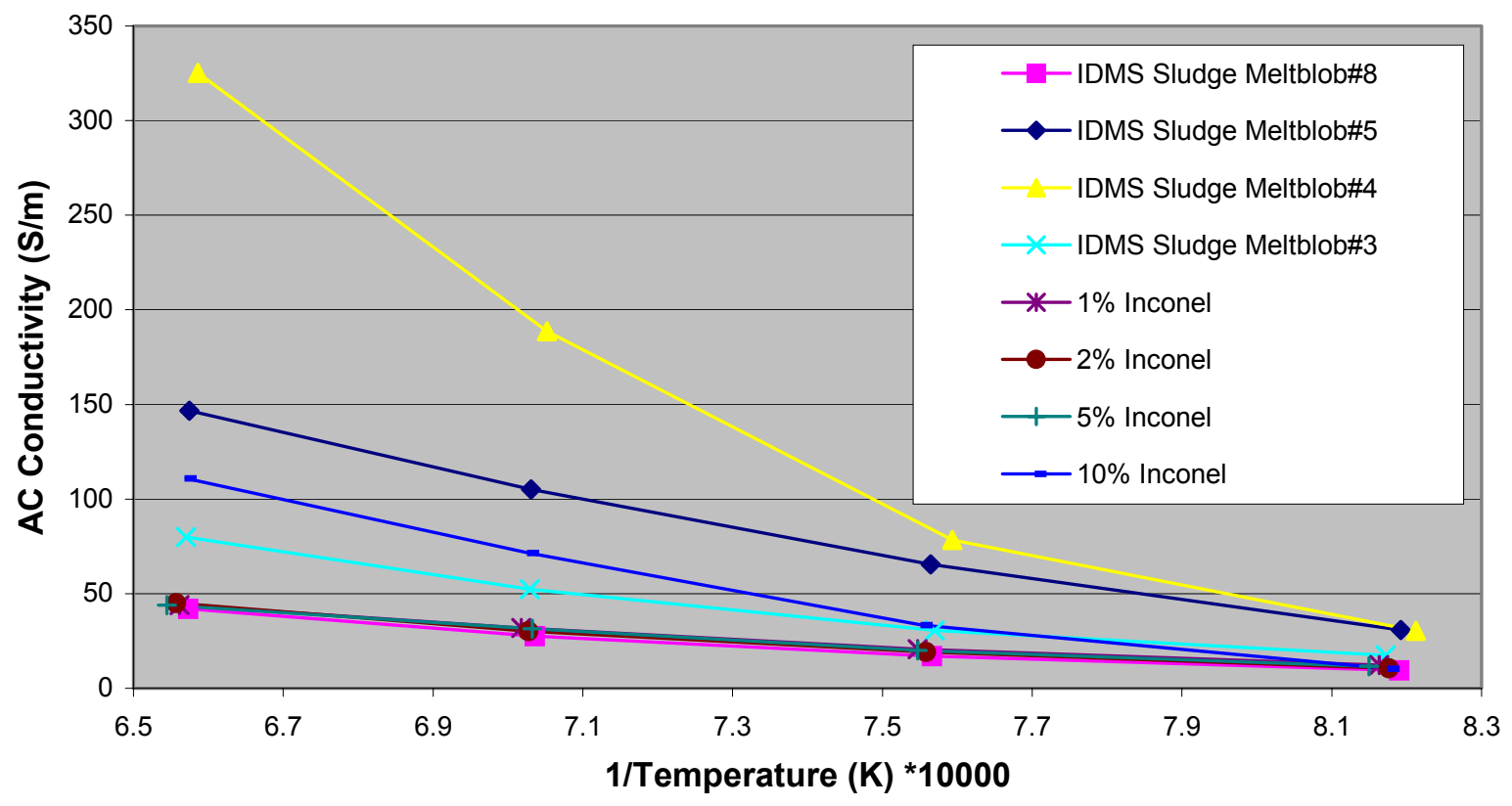

Figure 4-32 AC conductivity of DWPF frit containing Inconel 600

(Integrated DWPF Melter System (IDMS) data are shown for comparison.)

Figures 4.33 - 4.36 show the temperature dependence of AC conductivity of DWPF frit containing other conductivity surrogates, $\mathrm{Cr}_{2} \mathrm{O}_{3}, \mathrm{NiCr}_{2} \mathrm{O}_{4}, \mathrm{RuO}_{2}$, and $\mathrm{WO}_{3}$, respectively. Except the case of $\mathrm{NiCr}_{2} \mathrm{O}_{4}$, the additives showed a steady drop in conductivity with increase in the amount of additive until 5 wt. \%. Above this limit, the conductivity increased, indicating connectivity among additive particles that establish low resistance paths for current flow in the melt. In the case of $\mathrm{NiCr}_{2} \mathrm{O}_{4}$, the conductivity continued to decrease with $10 \mathrm{wt}$ \% addition. $\mathrm{Cr}_{2} \mathrm{O}_{3}$ showed conductivity data closely following the data of $\mathrm{RuO}_{2}$. 


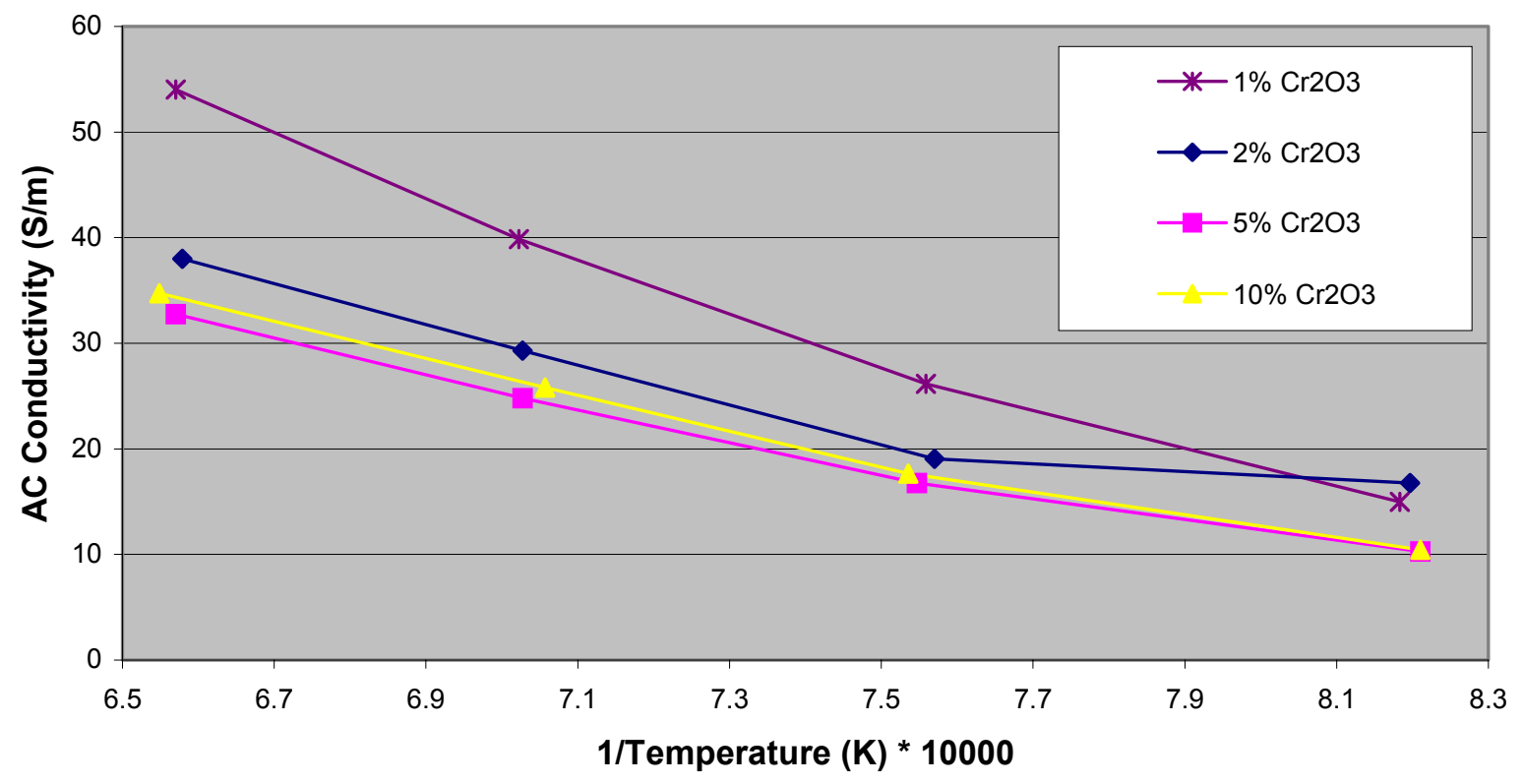

Figure 4-33 AC conductivity of DWPF frit containing $\mathrm{Cr}_{2} \mathrm{O}_{3}$

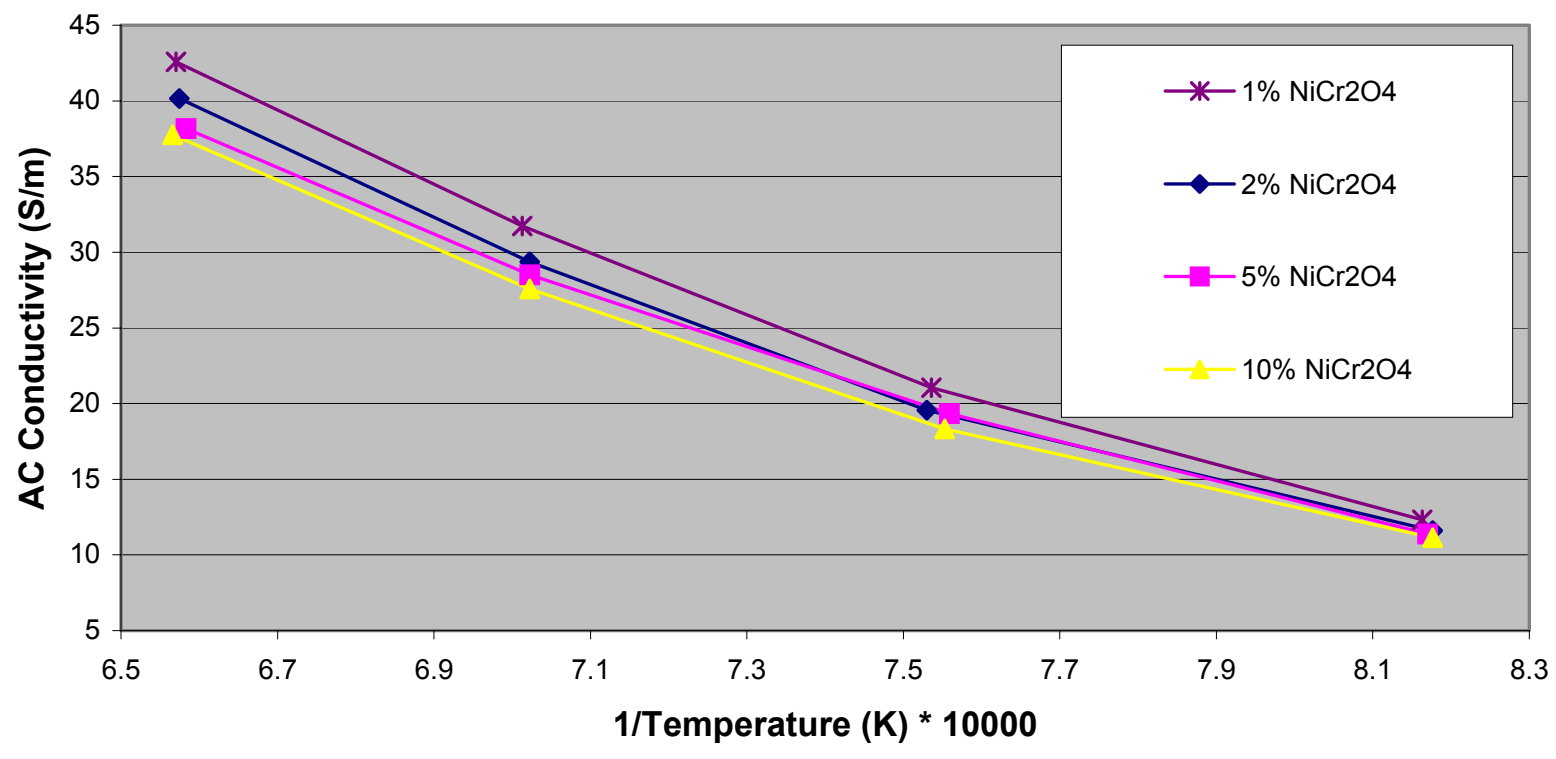

Figure 4-34 AC conductivity of DWPF frit containing $\mathrm{NiCr}_{2} \mathrm{O}_{4}$ 


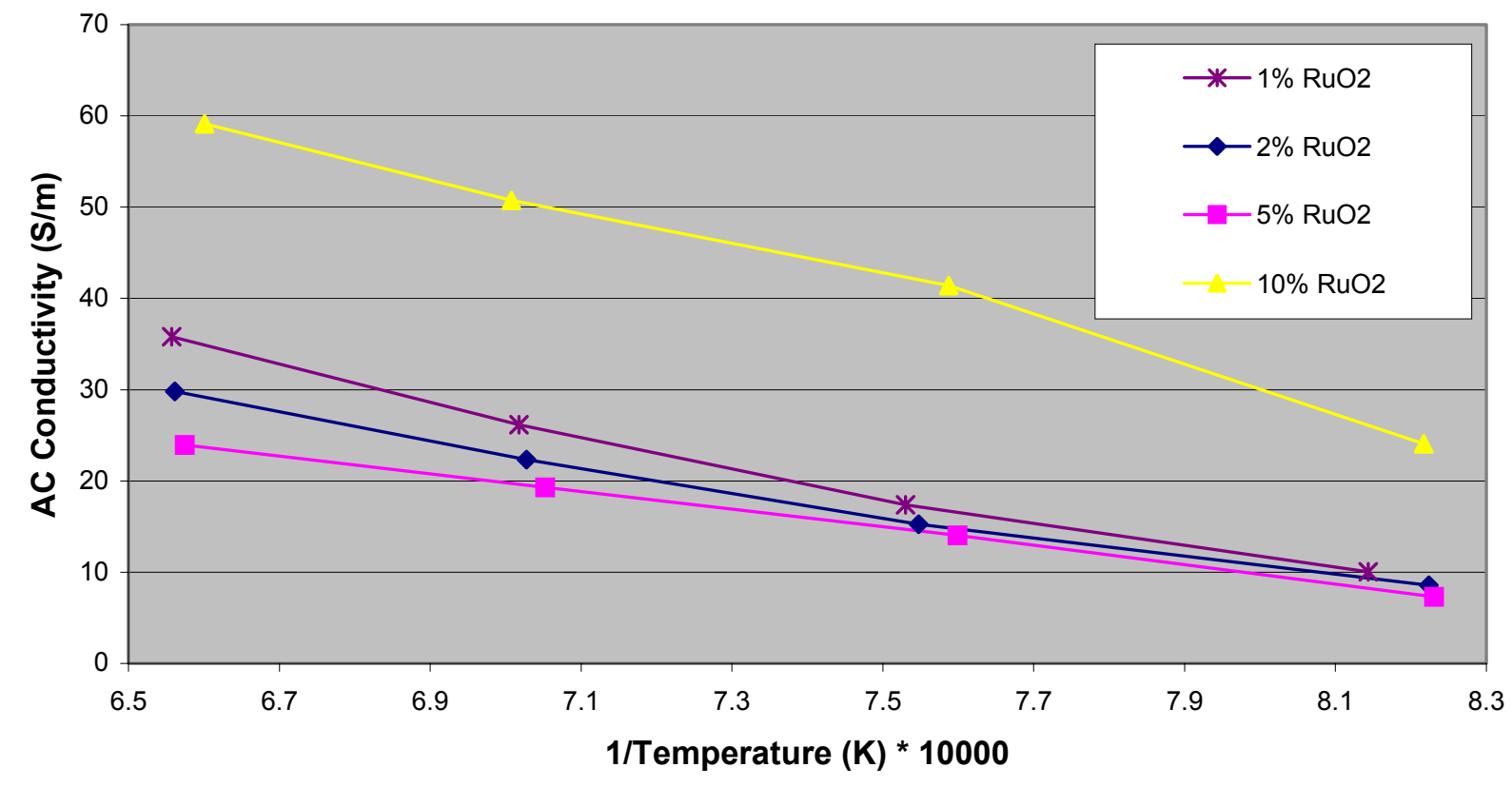

Figure 4-35 AC conductivity of DWPF frit containing $\mathrm{RuO}_{2}$

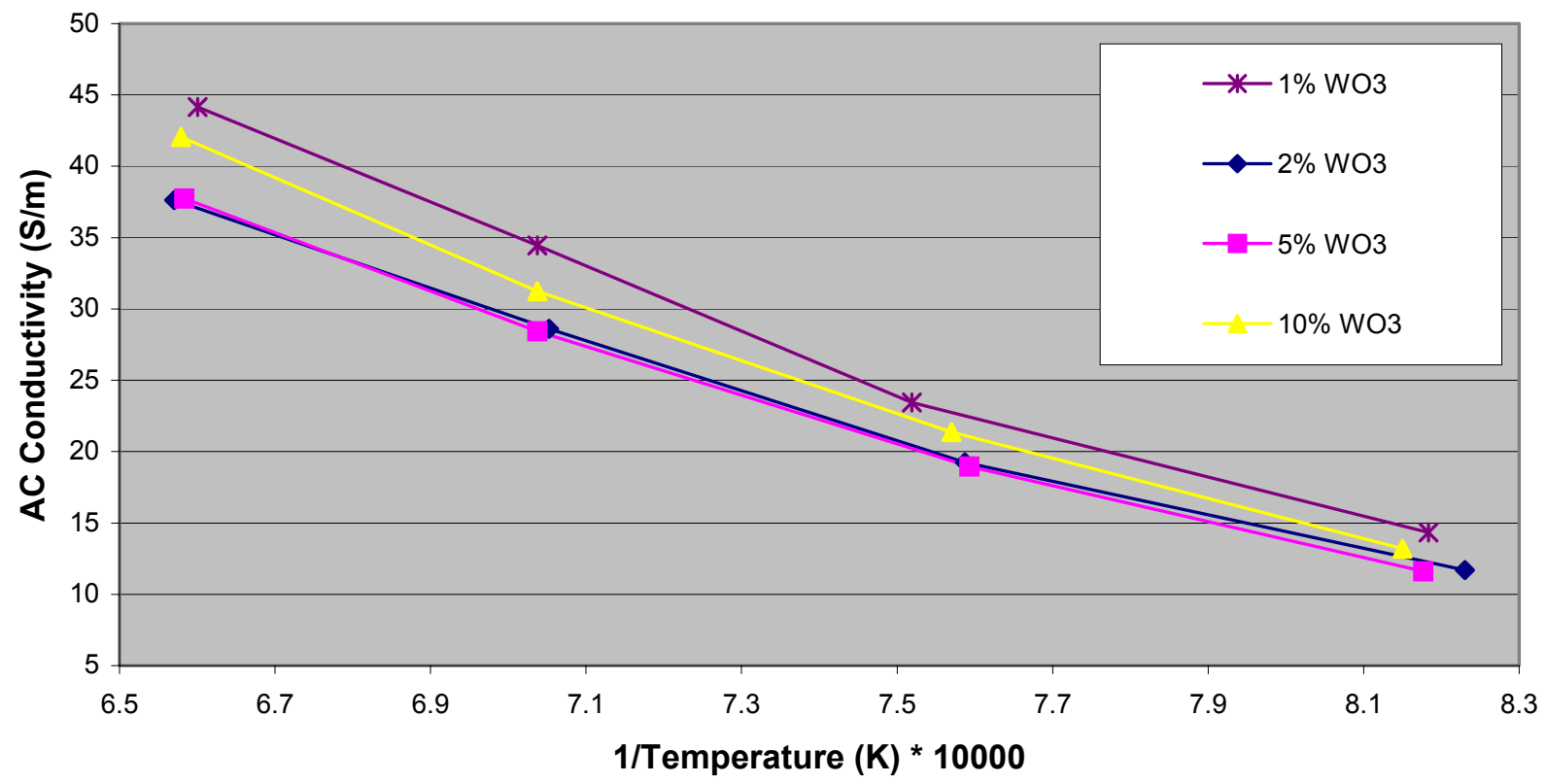

Figure 4-36 AC conductivity of DWPF frit containing $\mathrm{WO}_{3}$ 


\subsection{Conclusion and Recommendation}

1. Limited data on noble metals solubility in silicate glass exists in the literature. Data on Ru-solubility is inconclusive. Currently, no data exists on noble metals surrogate solubility in nuclear waste glass melts. A systematic study of the solubility of noble metals (mainly $\mathrm{Ru}$ ) as well as suitable surrogates in nuclear waste glass melts is recommended.

2. Overview of existing literature on noble metals in waste melts and melter testing indicates that $\mathrm{RuO}_{2}$ is the most commonly detected phase present. Hence, the present investigation is focused at $\mathrm{RuO}_{2}$ and its potential suitable surrogates.

3. Thermodynamic and density consideration supports the promise of using W-O system as a surrogate for $\mathrm{Ru}$ as well as $\mathrm{RuO}_{2}$. $\mathrm{WO}_{2}\left(12.11 \mathrm{~g} / \mathrm{cm}^{3}\right)$ can act as a surrogate for $\mathrm{Ru}\left(12.30 \mathrm{~g} / \mathrm{cm}^{3}\right)$ under reducing conditions. Alternatively, $\mathrm{WO}_{3}\left(7.20 \mathrm{~g} / \mathrm{cm}^{3}\right)$ can act as a surrogate for $\mathrm{RuO}_{2}\left(6.97 \mathrm{~g} / \mathrm{cm}^{3}\right)$ under oxidizing conditions. $\mathrm{WO}_{3}$ is selected as the potential surrogate for $\mathrm{RuO}_{2}$ in this investigation. Cost data also supports this selection.

4. Double-crucible settling study indicates formation of more spinel crystals have formed at $950^{\circ} \mathrm{C}$ and started settling at $1000^{\circ} \mathrm{C}$, with $\mathrm{RuO}_{2}$ as well as $\mathrm{WO}_{3}$ in MS-7 glass. SEM, EDS, and XRD data have supported this observation. XRD data has not shown any other phase formed. Ru has been found to partition readily in the spinel phase, as compared to $\mathrm{W}$.

5. Crystallization study has shown formation of Trevorite phase in the sample with addition of $\mathrm{RuO}_{2}$ as well as $\mathrm{WO}_{3}$. Unlike $\mathrm{WO}_{3}$, the undissolved $\mathrm{RuO}_{2}$ is detected by the XRD.

6. An order of magnitude increase in viscosity values has been observed as addition of $\mathrm{NiCr}_{2} \mathrm{O}_{4}$ (one of potential surrogates studied in this project) increased from $1 \mathrm{wt} \% \%$ to $10 \mathrm{wt} \%$ in modified NCAW glass melts. This also results in an increase in shear stress of rotating spindle in rheology testing. This data clearly establishes the consequences of increased spinel formation and accumulation.

7. High temperature optical microscopy results show floating nodular aggregates of $\mathrm{RuO}_{2}$ at higher temperature $\left(>900^{\circ} \mathrm{C}\right)$ due to its insolubility in the MS-7 melt. On the contrary, $\mathrm{NiCr}_{2} \mathrm{O}_{4}$ dissolved completely in the test melt.

8. Partitioning study of noble metal species $\left(\mathrm{Ru}\right.$ and $\left.\mathrm{RuO}_{2}\right)$ and the surrogate species $\left(\mathrm{W}\right.$ and $\left.\mathrm{WO}_{3}\right)$ between spinel (nonstoichiometric $\mathrm{MgAl}_{2} \mathrm{O}_{4}$ ) and model glass melt (MS-7) indicates striking similarity between $\mathrm{RuO}_{2}$ and $\mathrm{WO}_{3}$ in their interaction with the glass melt. Based on these results, use of $\mathrm{WO}_{3}$ as a suitable surrogate for $\mathrm{RuO}_{2}$ is recommended.

9. Conductivity data indicate that effect of $\mathrm{Cr}_{2} \mathrm{O}_{3}$ addition closely follow that of $\mathrm{RuO}_{2}$ in DWPF frit.

10. In the absence of advanced data on solubility of the noble metals and surrogates, a research-scale melter (RSM) test is recommended before testing the surrogate in an engineering scale melter. RSM test will provide key processing data that will help planning the engineering scale melter test. 


\subsection{References}

Sundaram, S. K and J. M. Perez. 2000. Noble Metals and Spinel Settling in High Level Waste Glass Melters. PNNL-13347, September 2000.

Hutson, N. D. 1992. Integrated DWPF Melter System (IDMS) Campaign Report: Hanford Waste Vitrification Plant (HWVP) Process Demonstration (U). WSRC-TR-92-0403, Rev. 1, Westinghouse Savannah River Company, Savannah River Technology Center, Aiken, South Carolina; Hutson, N. D., and M. E. Smith. 1992. "The Behavior and Effects of the Noble Metals in the DWPF Melter System." Proceedings of the High Level Radioactive Waste Management Conference, American Nuclear Society, La Grange Park, Illinois. 1:541-548.

Hutson, N. D. 1993. IDMS Task Summary Report Part 1: The Behavior and Effects of the Noble Metals in the DWPF Melter System. WSRC-TR-93-0458, Savannah River Technology Center, Aiken, South Carolina.

Hutson, N. D., J. R. Zamecnik, M. E. Smith, D. H. Miller, and J.A. Ritter. 1991. Integrated DWPF Melter System (IDMS) Campaign Report: The First Two Noble Metals Operations (U). WSRC-TR-91400, Defense Waste Processing Technology, Savannah River Laboratory, Aiken, South Carolina.

Bailer, J. C., H. J. Emel] us, T. Nyholm, and A. F. Trotman-Dickenson. 1973. Comprehensive Inorganic Chemistry, Vol. 5, Pergamon, New York, 1189-1209.

Mukerji, J and S. R. Biswas. 1967. "Solubility of Ruthenium in Soda-Silica Glass," Cent. Glass Ceram. Res. Inst. Bull., 14, 30-34.

Biswas, S. R. and J. Mukerji. 1968. "Solubility of Ruthenium in Silicate and Phosphate Glasses," Cent. Glass Ceram. Res. Inst. Bull., 15, 99-103.

Mukerji, J and S. R. Biswas. 1971. "Oxidation States of Ruthenium in Glasses," Glass Technol., 12, 107111.

Mukerji, J. 1972. "Absorption Spectra of Ruthenium in Borosilicate, Phosphate, and Aluminoborophosphate Glasses," Glass Technol., 13, 135-137.

Mukerji, J. 1975. "ESR Spectra of Ruthenium in Glass,” Phys. Chem. Glasses, 16, 61.

Schreiber, H. R., F. A. Settle, Jr., P. L. Jamison, J. P. Eckenrode, and G. W. Headley. 1986. "Ruthenium in Glass-Forming Borosilicate Melts." J. Less Comm. Metals, 115, 145-154.

Borisov A., H. Palme, and B. Spettle. 1994. "Solubility of Palladium in Silicate Melts: Implications for Core Formation in the Earth." Geochim. Cosmochim. Acta., 58, 705-716.

Dingwell, D. B., H. St. C. Neill, W. Ertel, and B. Spettel. 1994. "The solubility and Oxidation State of Ni in Silicate Melt at Low Oxygen Fugacities: Results using a Mechanically Assisted Equilibrium Technique, Geochim. Cosmochim. Acta., 58, 1967-1974. 
Holzheid, A., A. Borisov, and H. Palme. 1994. "The Effect of Oxygen Fugacity and Temperature on Solubilities of Nickel, Cobalt, and Molybdenum in Silicate Melts." Geochim. Cosmochim. Acta., 58, 1975-1981.

W. Ertel, H. St. C. O’Neill, D. B. Dingwell, and B. Spetel. 1996. "Solubility of Tungsten in a Haplobasaltic Melt as a Function of Temperature and Oxygen Fugacity." Geochim. Cosmochim. Acta., 60(7), 1171-1180.

Capobianco, C. J. and M. J. Drake. 1990. "Partitioning of Ruthenium, Rhodium, and Palladium between Spinel and Silicate Melt and Implications for Platinum Group Element Fractionation Trends." Geochim. Cosmochim. Acta., 54, 869-874.

Klouzek, J., Alton, P. Hrma, and T. Plaisted. 2001. "Crucibel Study of Spinel Settling in Molten HighLevel Waste Glass.” Ceramic Transactions, Volume 119, 301-308.

Plaisted, T., J. Alton, B. Wilson, and P. Hrma. 2001. "Effect of Minor Component Addition on Spinel Crystallization in Simulated High-Level Waste Glass." Ceramic Transactions, Volume 119, 291-299.

LaMont, M. and P. Hrma. 1998. "A Crucible Study of Spinel Settling in a High-Level Waste Glass." Ceramic Transactions, Volume 23, 343-348. 


\section{Appendix A}

\section{Additional Noble Metal Partition Data (SEM/EDS)}



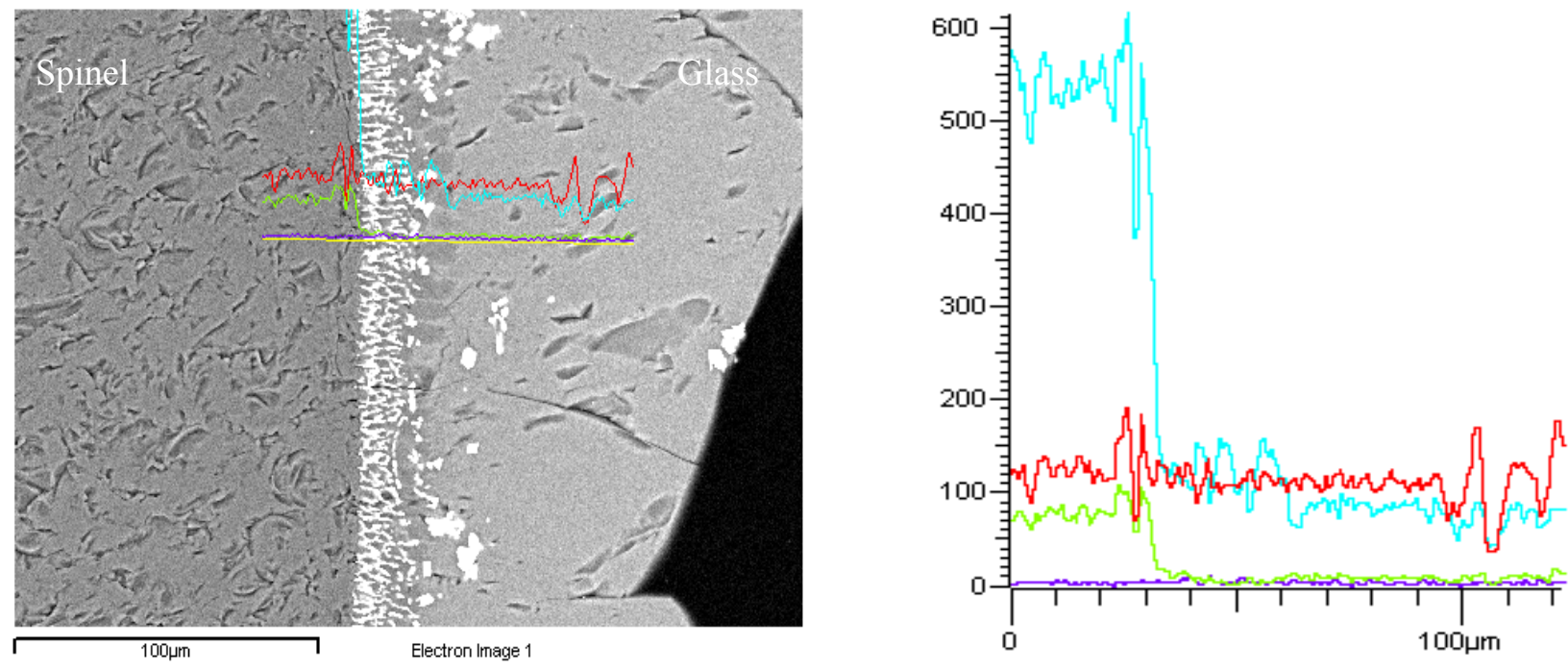

Figure A.1. SEM (Left) - Line EDS (Right) of Ru in MS-7 $\left(900^{\circ} \mathrm{C} / 15 \mathrm{~h}\right)$
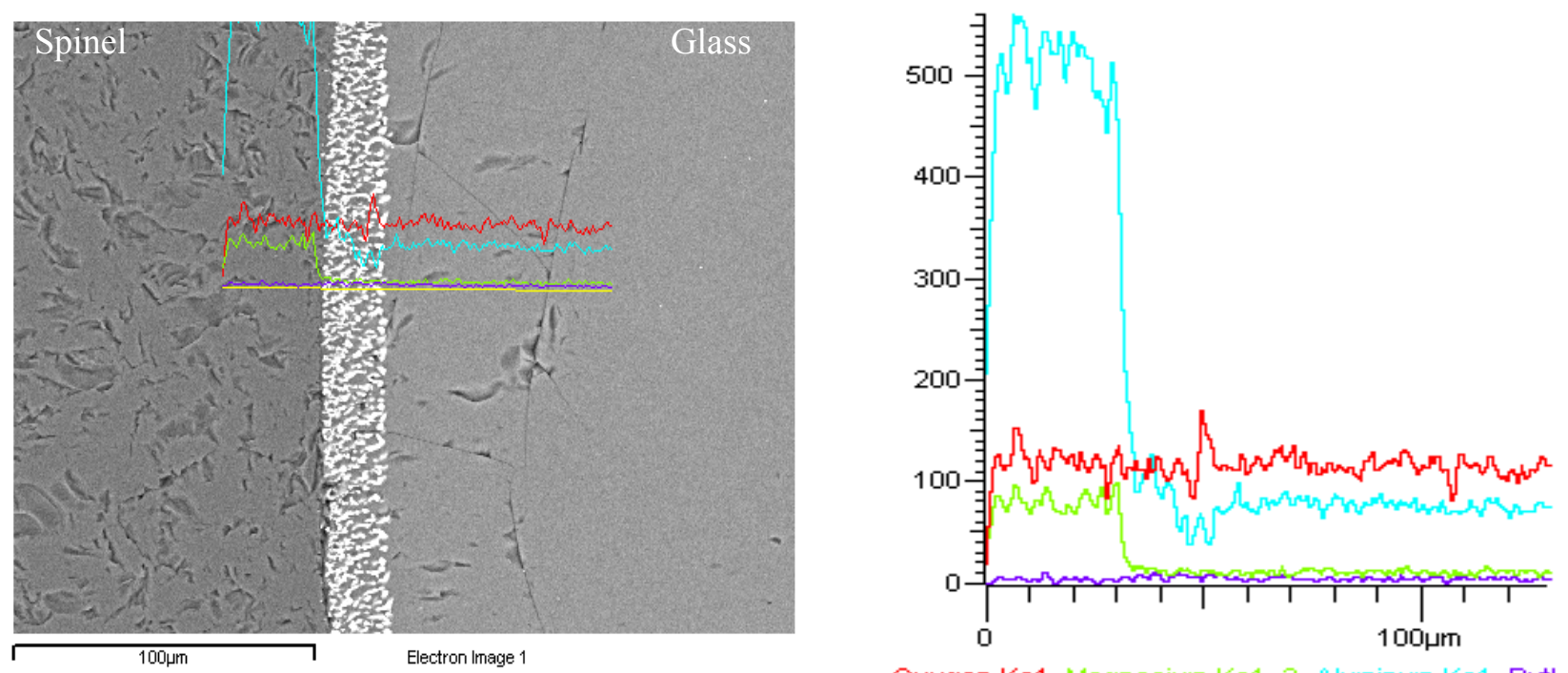

Figure A.2. SEM (Left) - Line EDS (Right) of Ru in MS-7 $\left(900^{\circ} \mathrm{C} / 19 \mathrm{~h}\right)$ 

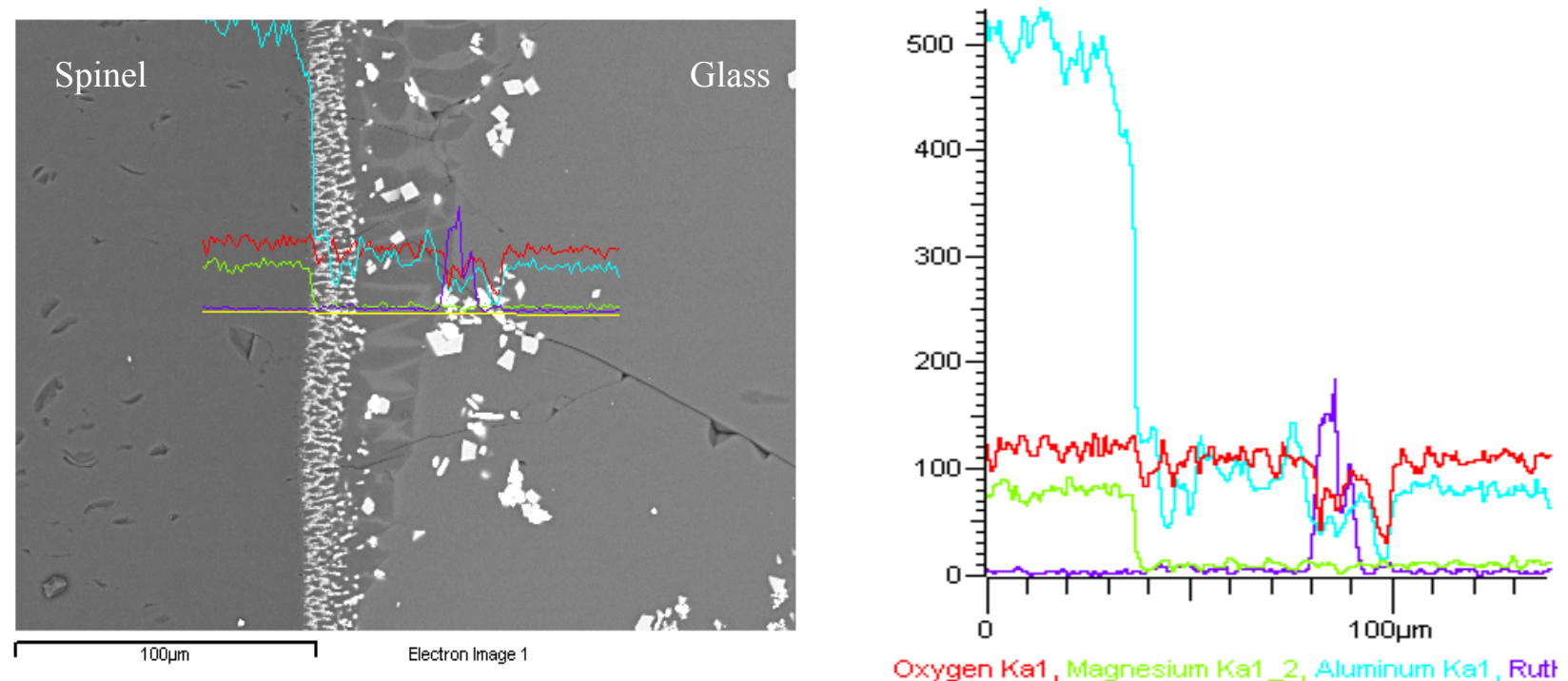

Figure A.3. SEM (Left) - Line EDS (Right) of Ru in MS-7 $\left(900^{\circ} \mathrm{C} / 23 \mathrm{~h}\right)$
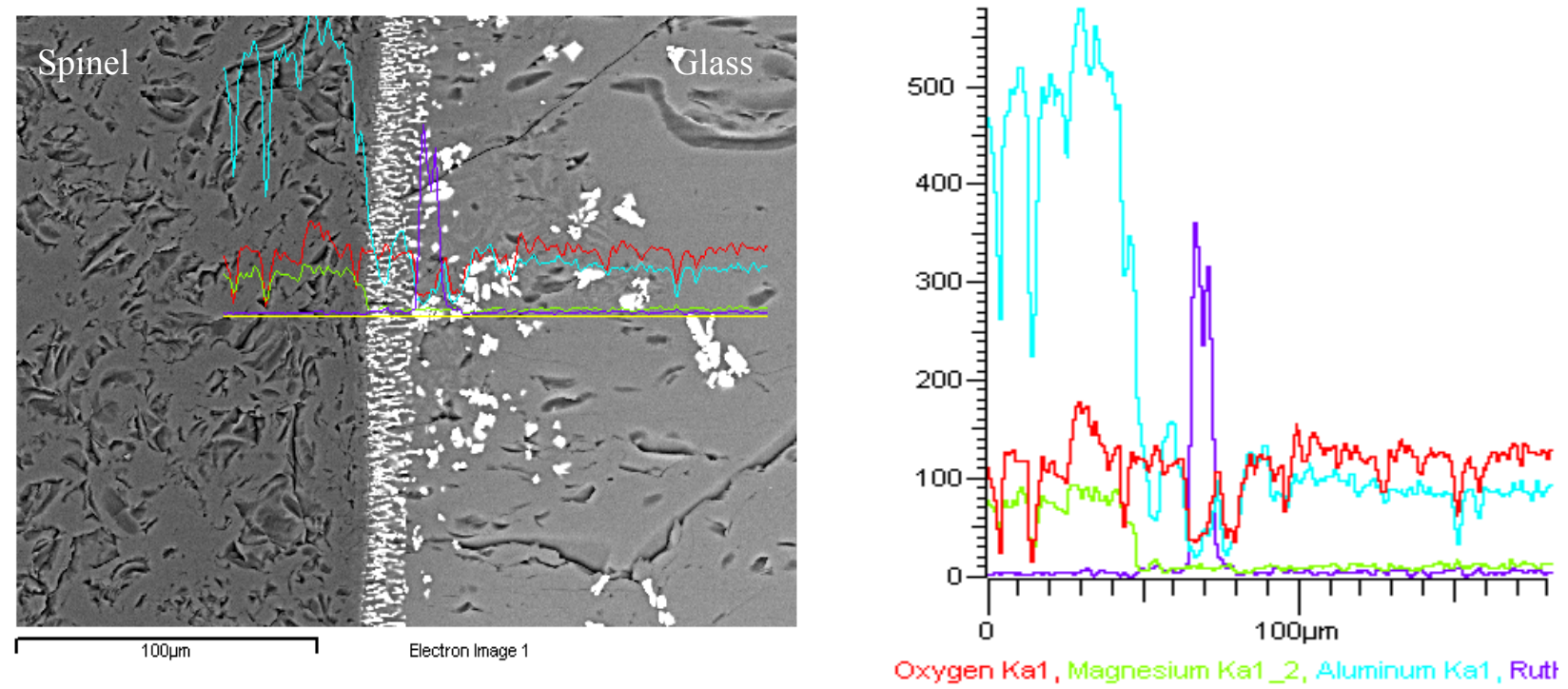

Figure A.4. SEM (Left) - Line EDS (Right) of Ru in MS-7 $\left(1000^{\circ} \mathrm{C} / 7 \mathrm{~h}\right)$ 

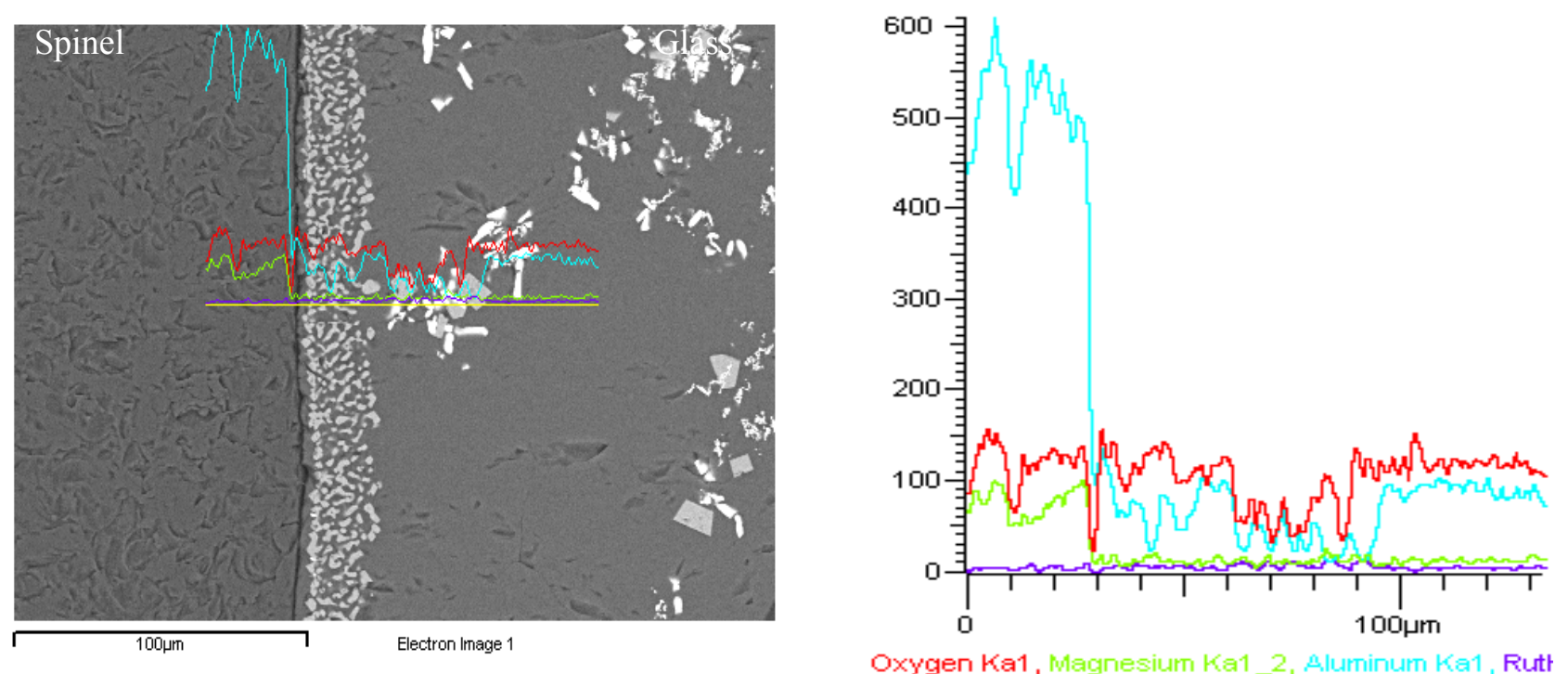

Figure A.5. SEM (Left) - Line EDS (Right) of Ru in MS-7 $\left(1000^{\circ} \mathrm{C} / 15 \mathrm{~h}\right)$
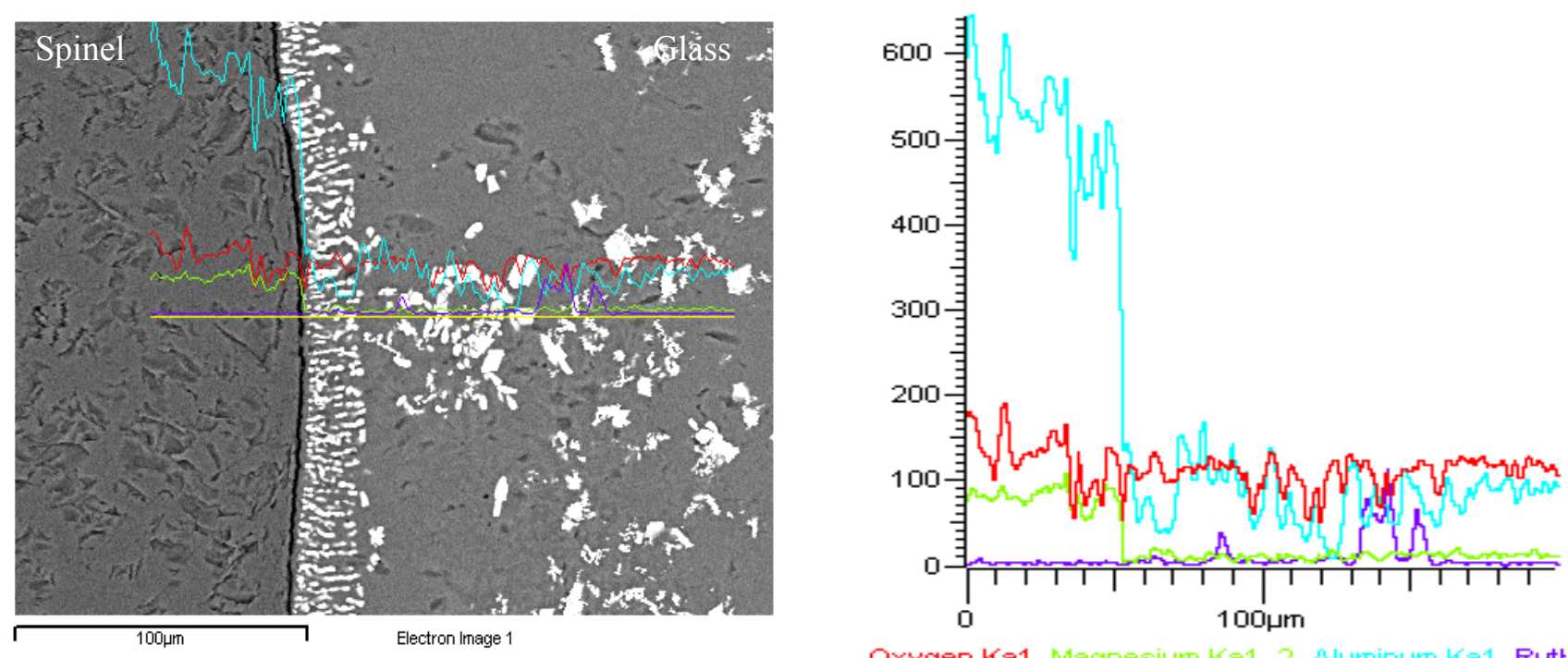

Figure A.6. SEM (Left) - Line EDS (Right) of Ru in MS-7 (1000'C/19h) 

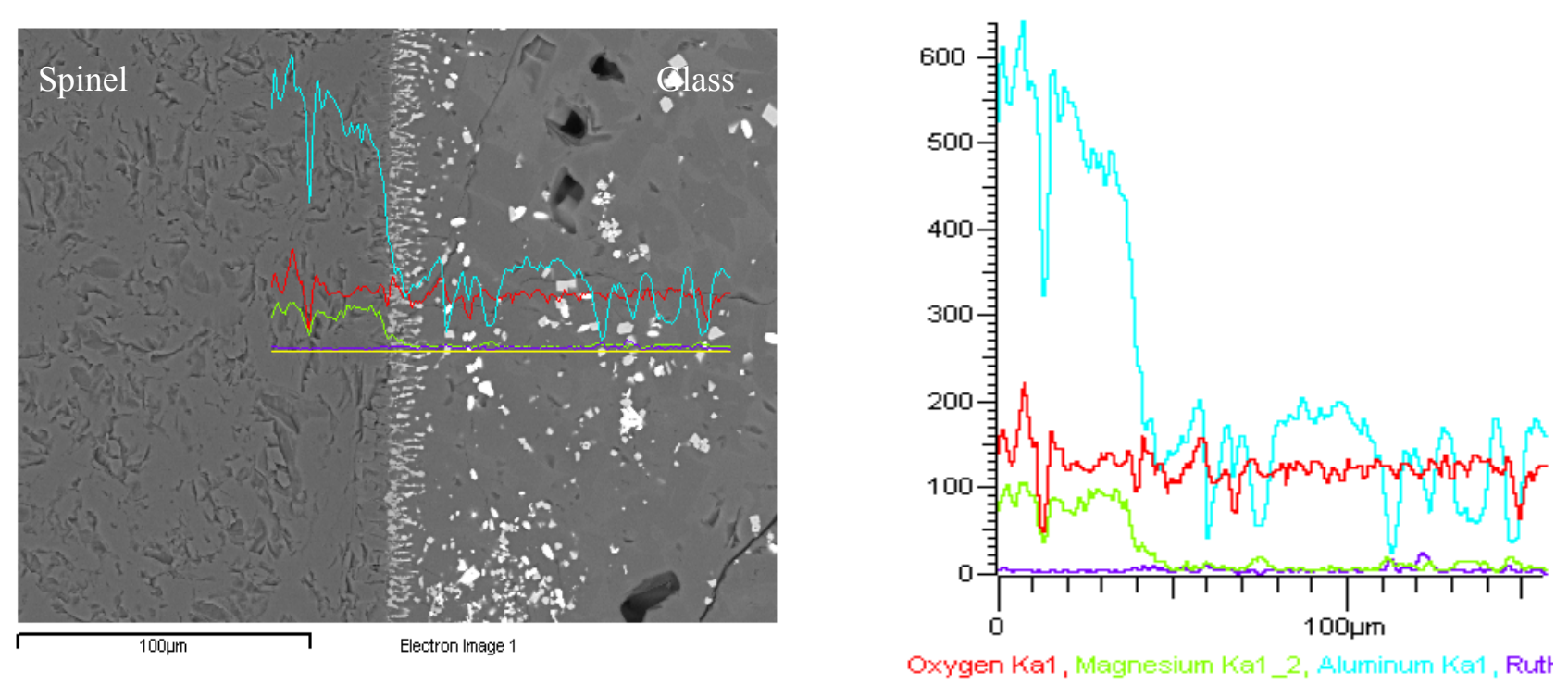

Figure A.7. SEM (Left) - Line EDS (Right) of Ru in MS-7 $\left(1000^{\circ} \mathrm{C} / 23 \mathrm{~h}\right)$
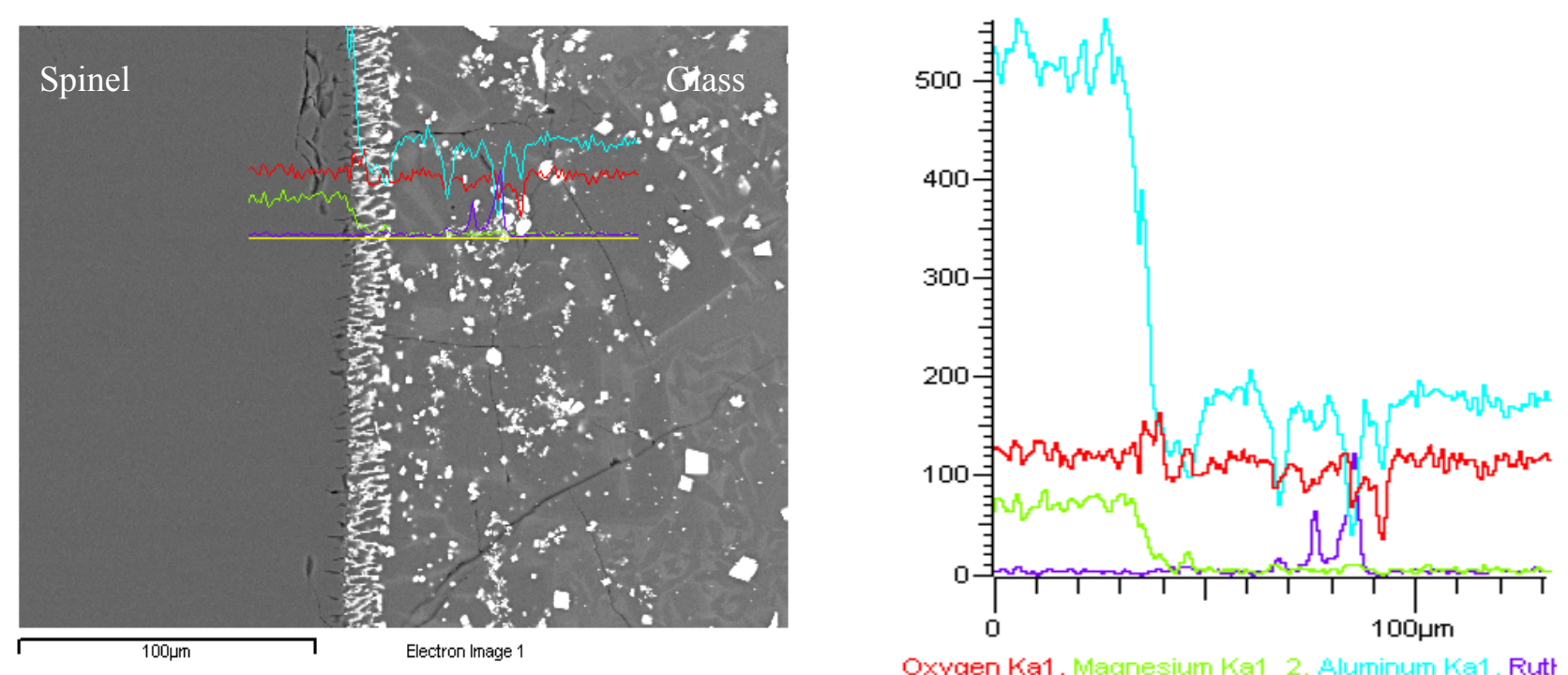

Oxygen Ka1, Magnesium Ka1_2, Aluminum Ka1, Rutt

Figure A.8. SEM (Left) - Line EDS (Right) of $\mathrm{RuO}_{2}$ in $\mathrm{MS}-7\left(900^{\circ} \mathrm{C} / 15 \mathrm{~h}\right)$ 

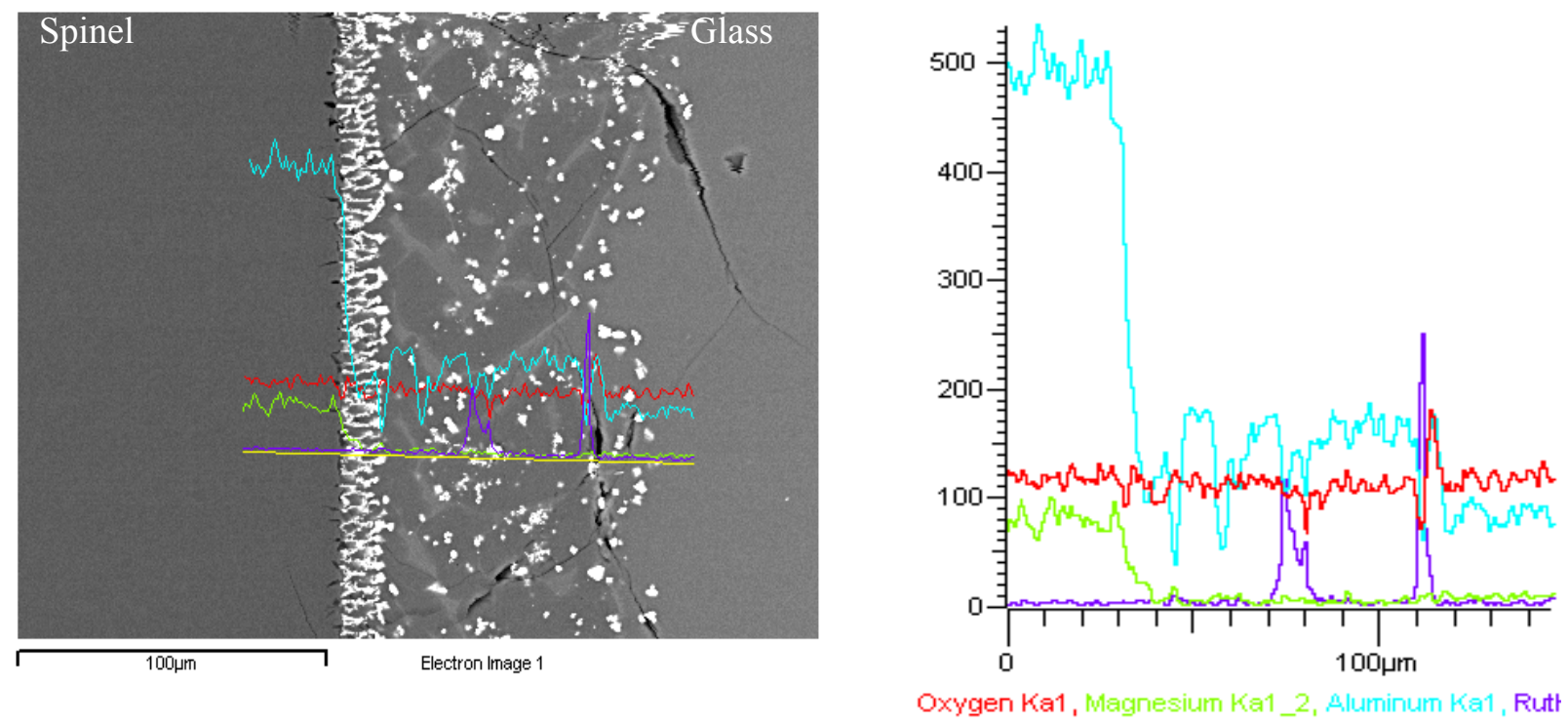

Figure A.9. SEM (Left) - Line EDS (Right) of $\mathrm{RuO}_{2}$ in $\mathrm{MS}-7\left(900^{\circ} \mathrm{C} / 19 \mathrm{~h}\right)$
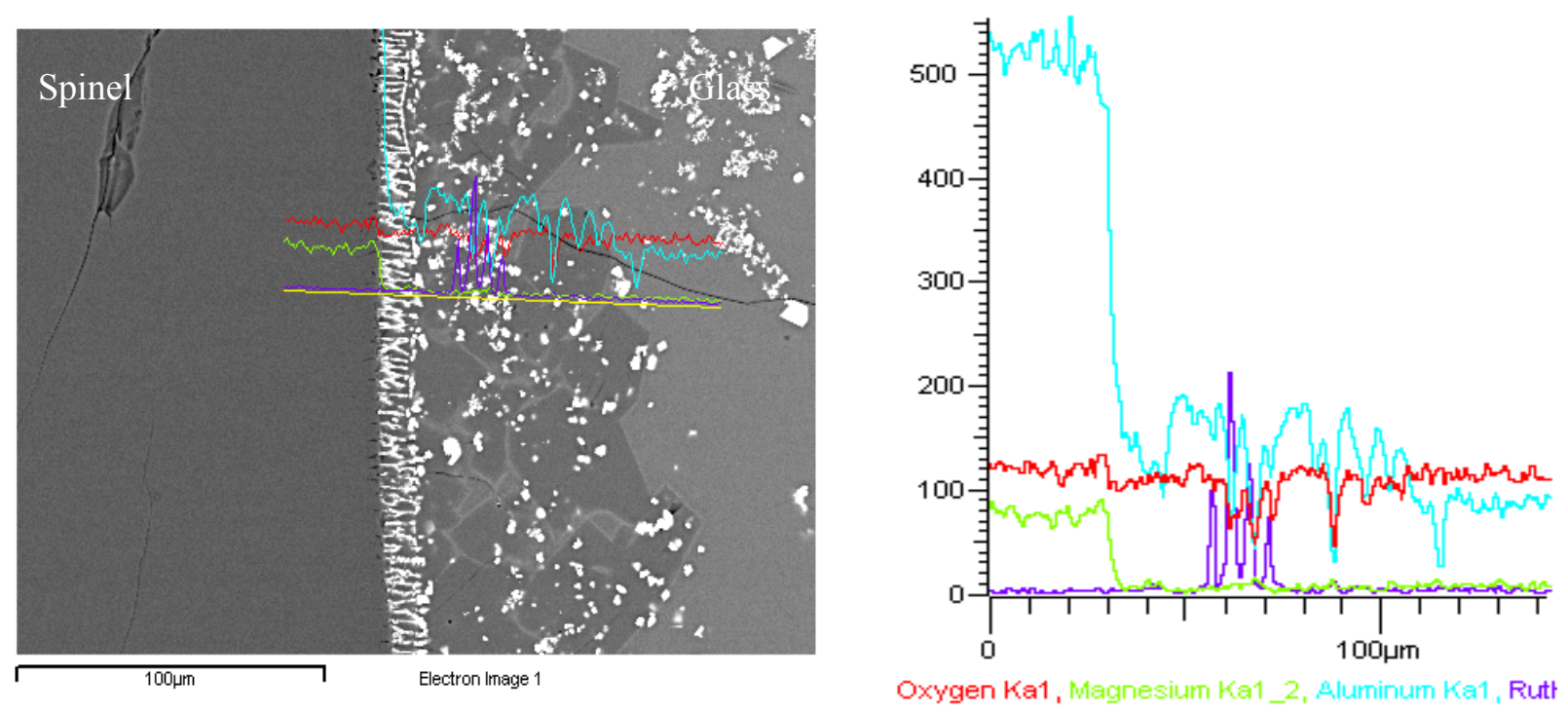

Figure A.10. SEM (Left) - Line EDS (Right) of $\mathrm{RuO}_{2}$ in $\mathrm{MS}-7\left(900^{\circ} \mathrm{C} / 23 \mathrm{~h}\right)$ 

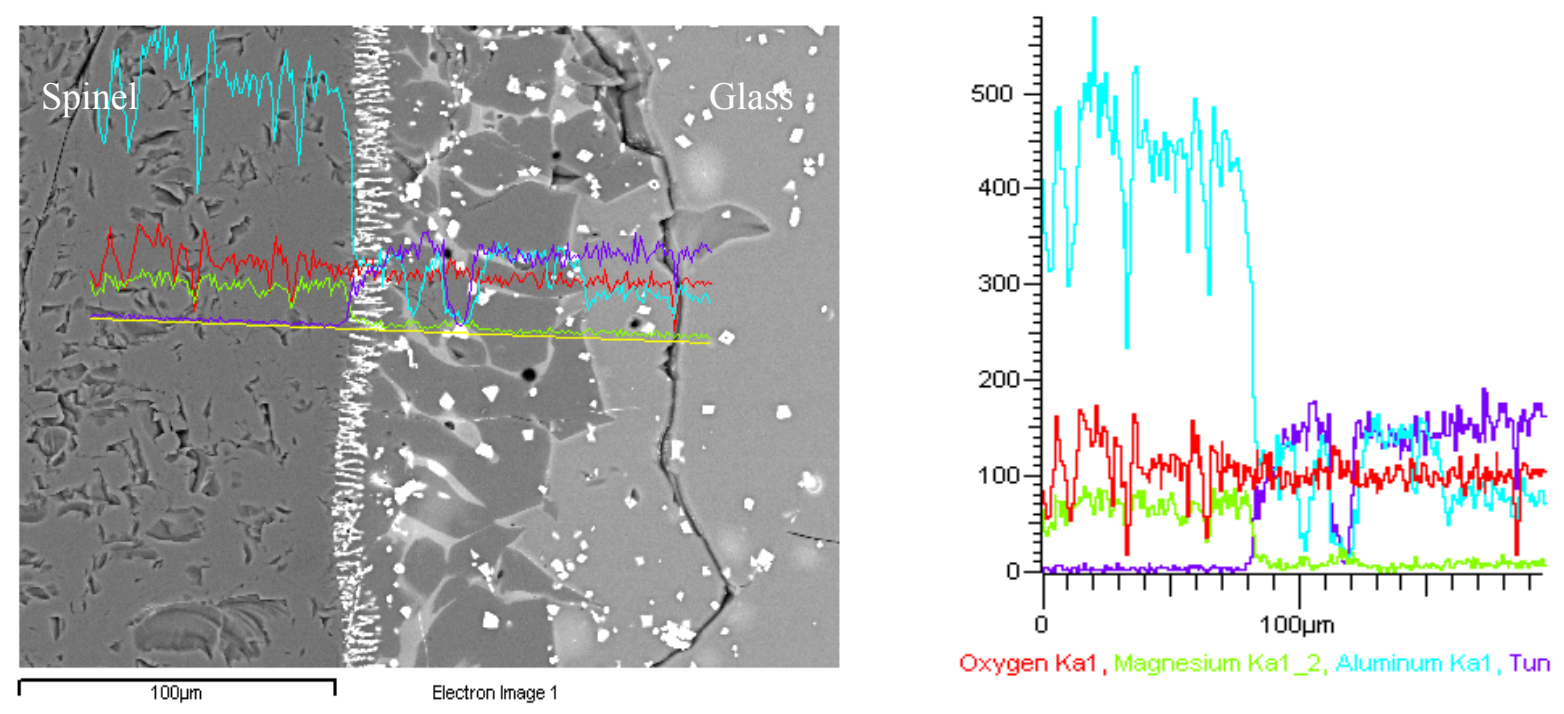

Figure A.11. SEM (Left) - Line EDS (Right) of W in MS-7 $\left(900^{\circ} \mathrm{C} / 15 \mathrm{~h}\right)$
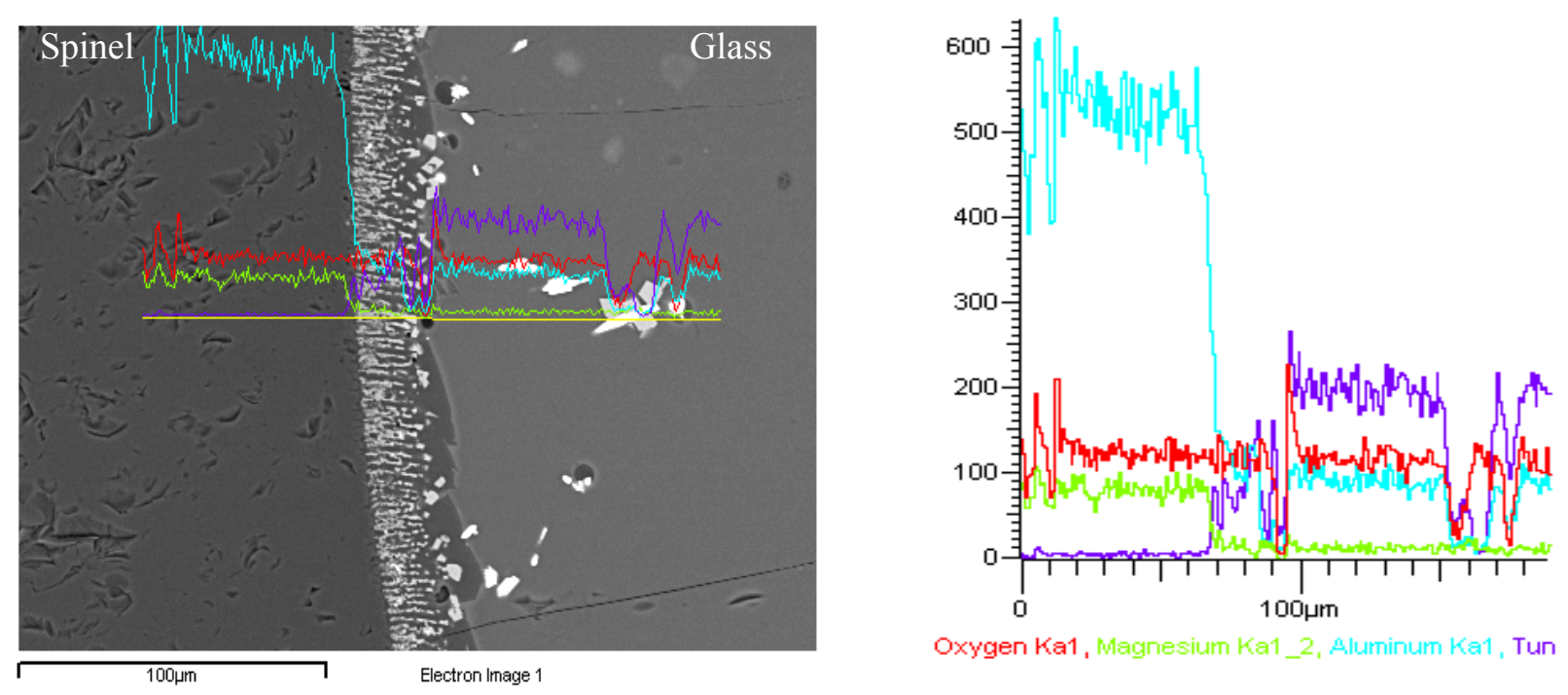

Figure A.12. SEM (Left) - Line EDS (Right) of W in MS-7 $\left(900^{\circ} \mathrm{C} / 19 \mathrm{~h}\right)$ 

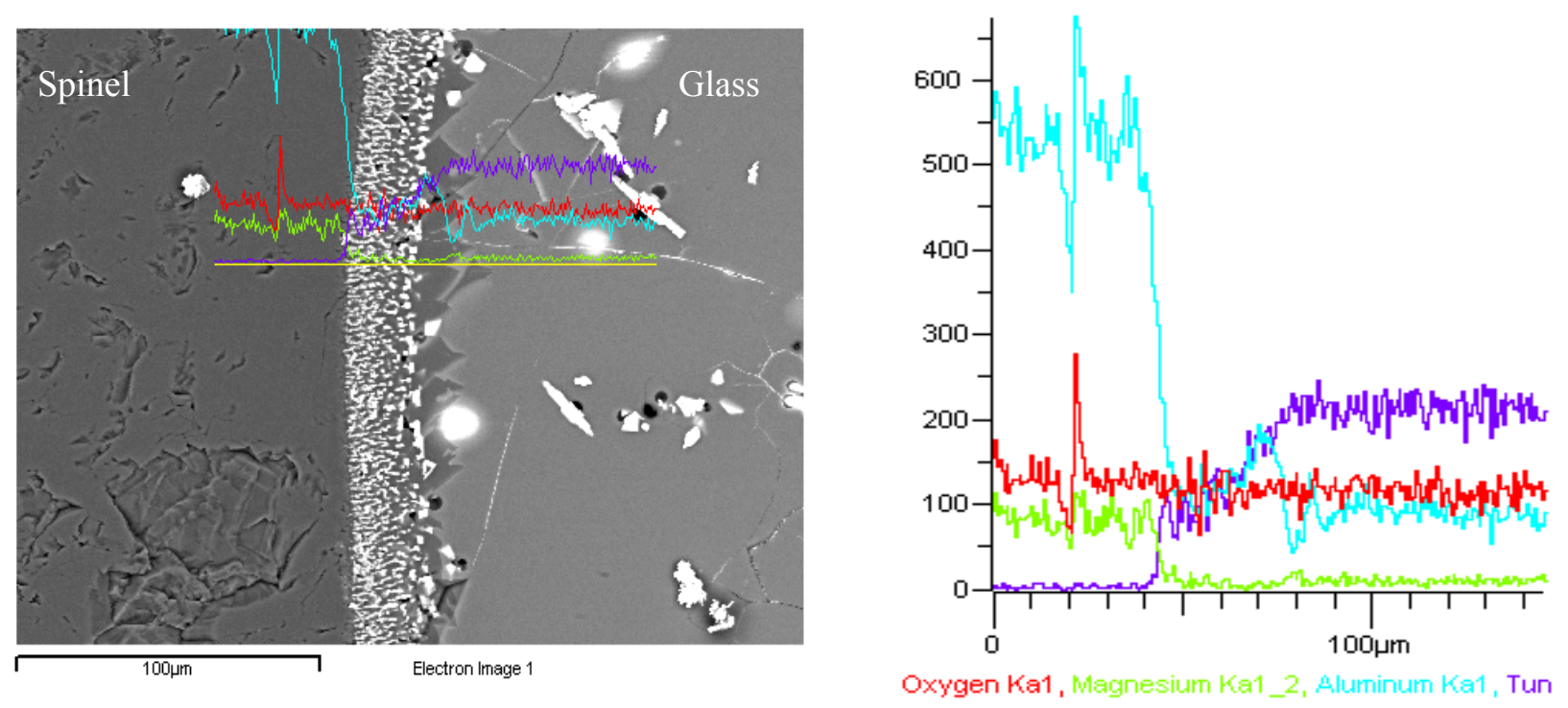

Figure A.13. SEM (Left) - Line EDS (Right) of W in MS-7 $\left(900^{\circ} \mathrm{C} / 23 \mathrm{~h}\right)$
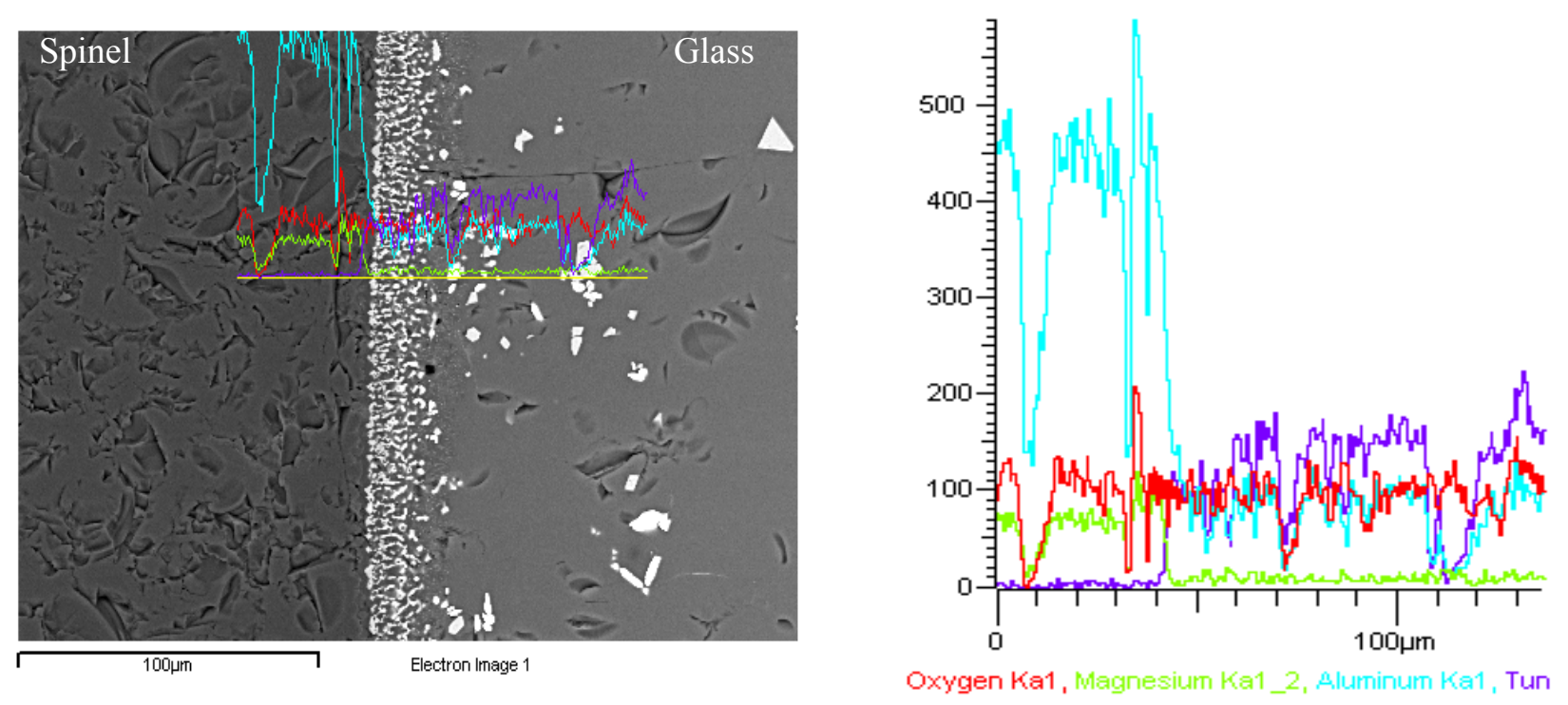

Figure A.14. SEM (Left) - Line EDS (Right) of W in MS-7 $\left(1000^{\circ} \mathrm{C} / 7 \mathrm{~h}\right)$ 

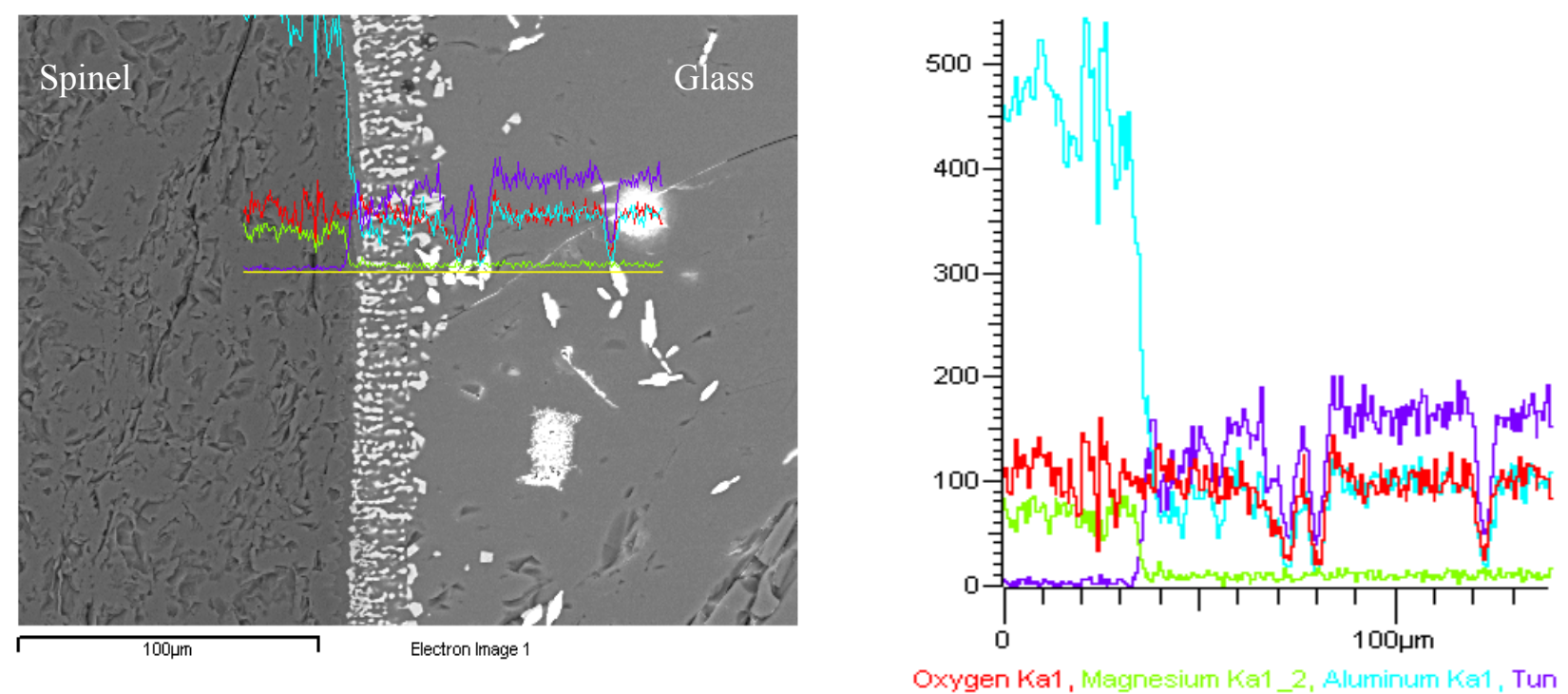

Figure A.15. SEM (Left) - Line EDS (Right) of W in MS-7 $\left(1000^{\circ} \mathrm{C} / 15 \mathrm{~h}\right)$
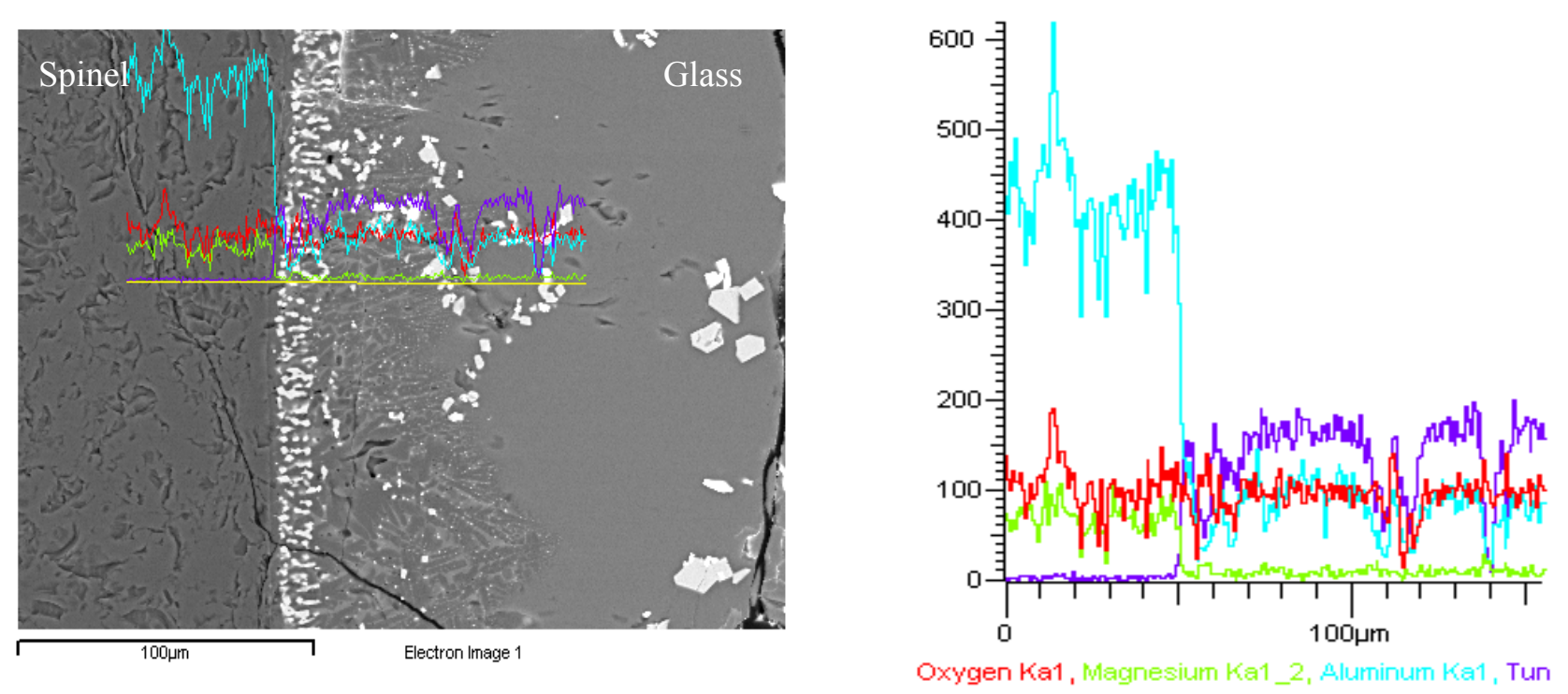

Figure A.16. SEM (Left) - Line EDS (Right) of W in MS-7 $\left(1000^{\circ} \mathrm{C} / 19 \mathrm{~h}\right)$ 

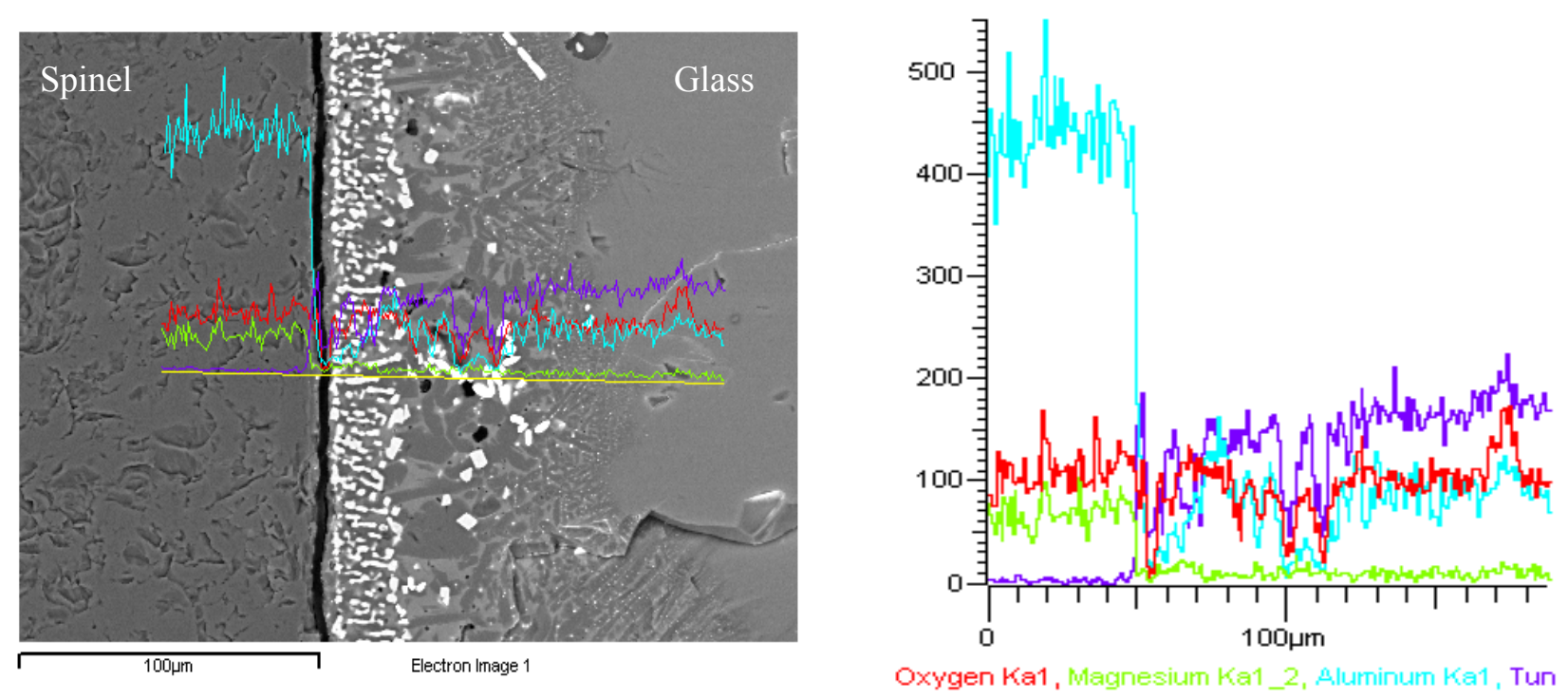

Figure A.17. SEM (Left) - Line EDS (Right) of W in MS-7 $\left(1000^{\circ} \mathrm{C} / 23 \mathrm{~h}\right)$
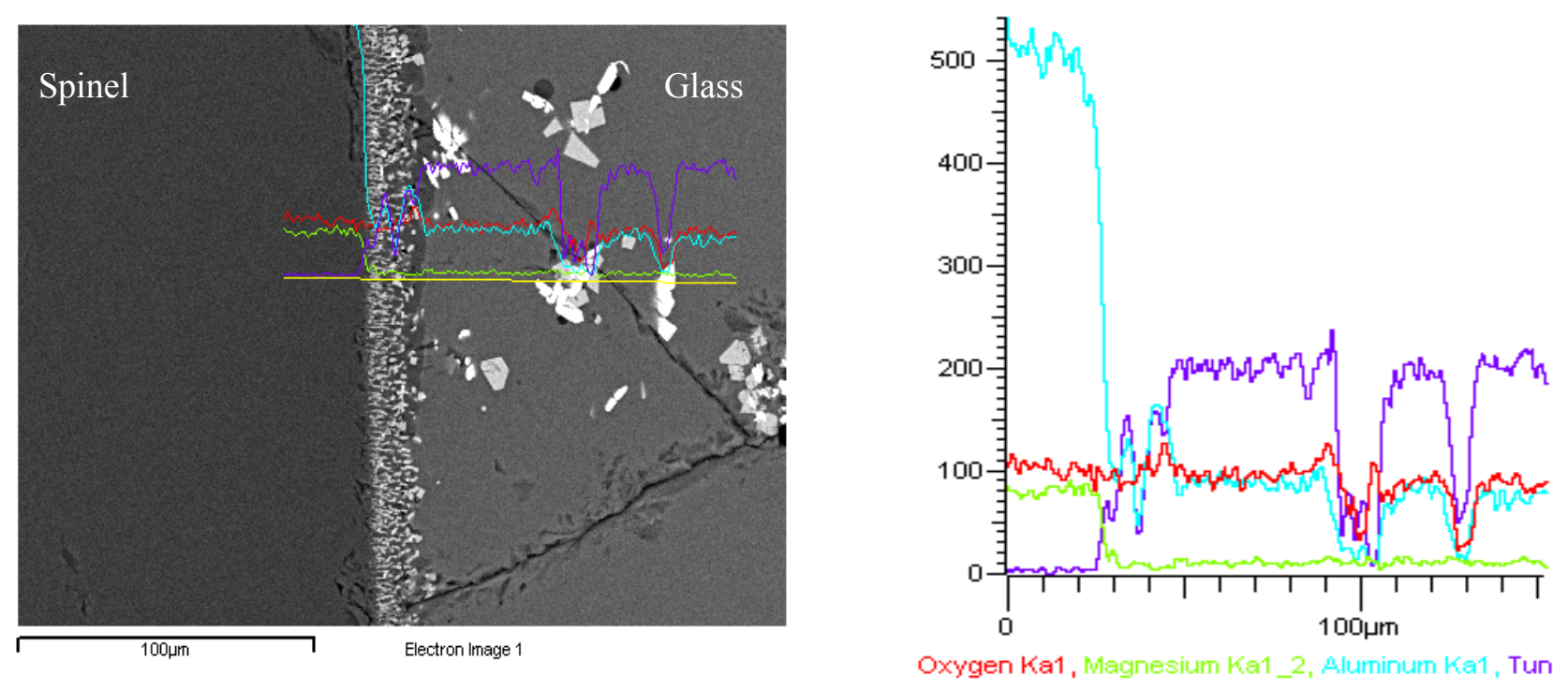

Figure A.18. SEM (Left) - Line EDS (Right) of $\mathrm{WO}_{3}$ in $\mathrm{MS}-7\left(900^{\circ} \mathrm{C} / 15 \mathrm{~h}\right)$ 

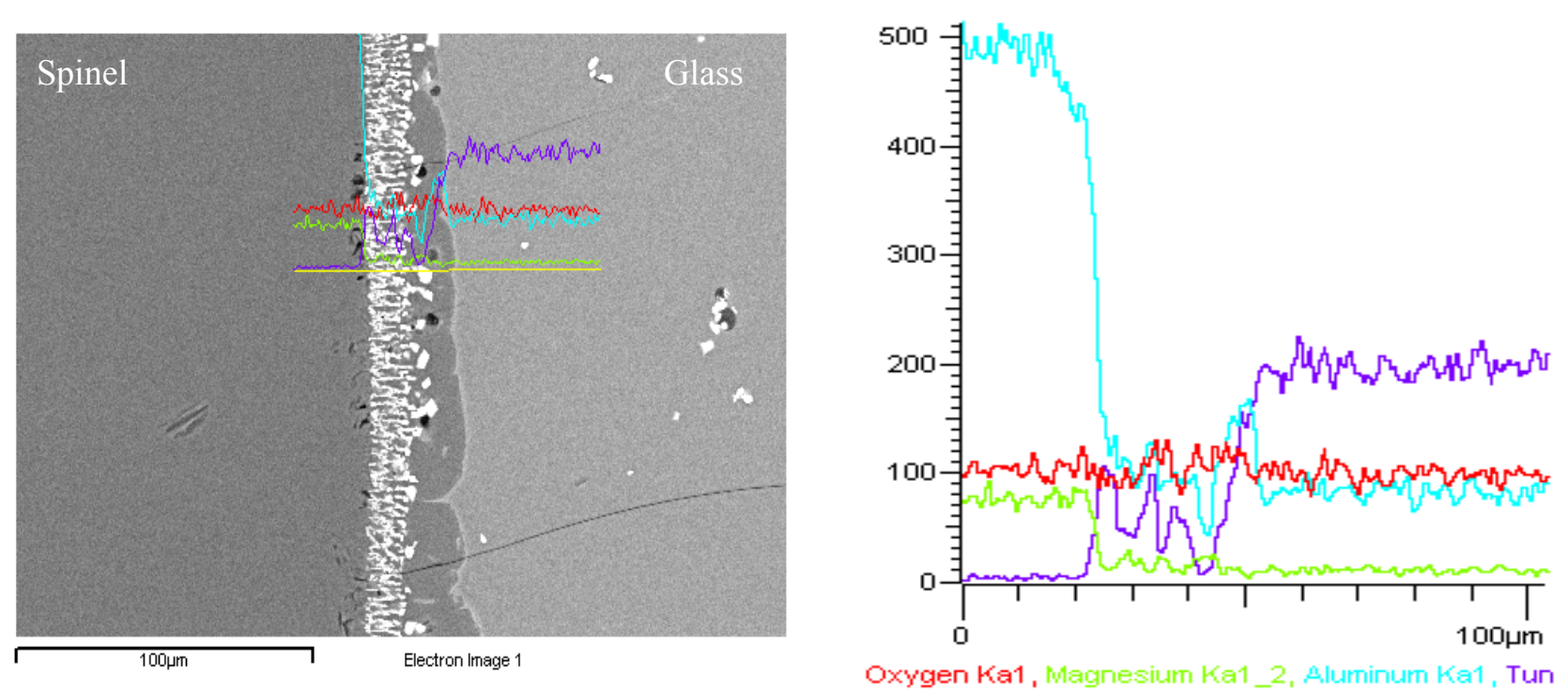

Figure A.19. SEM (Left) - Line EDS (Right) of $\mathrm{WO}_{3}$ in $\mathrm{MS}-7\left(900^{\circ} \mathrm{C} / 19 \mathrm{~h}\right)$
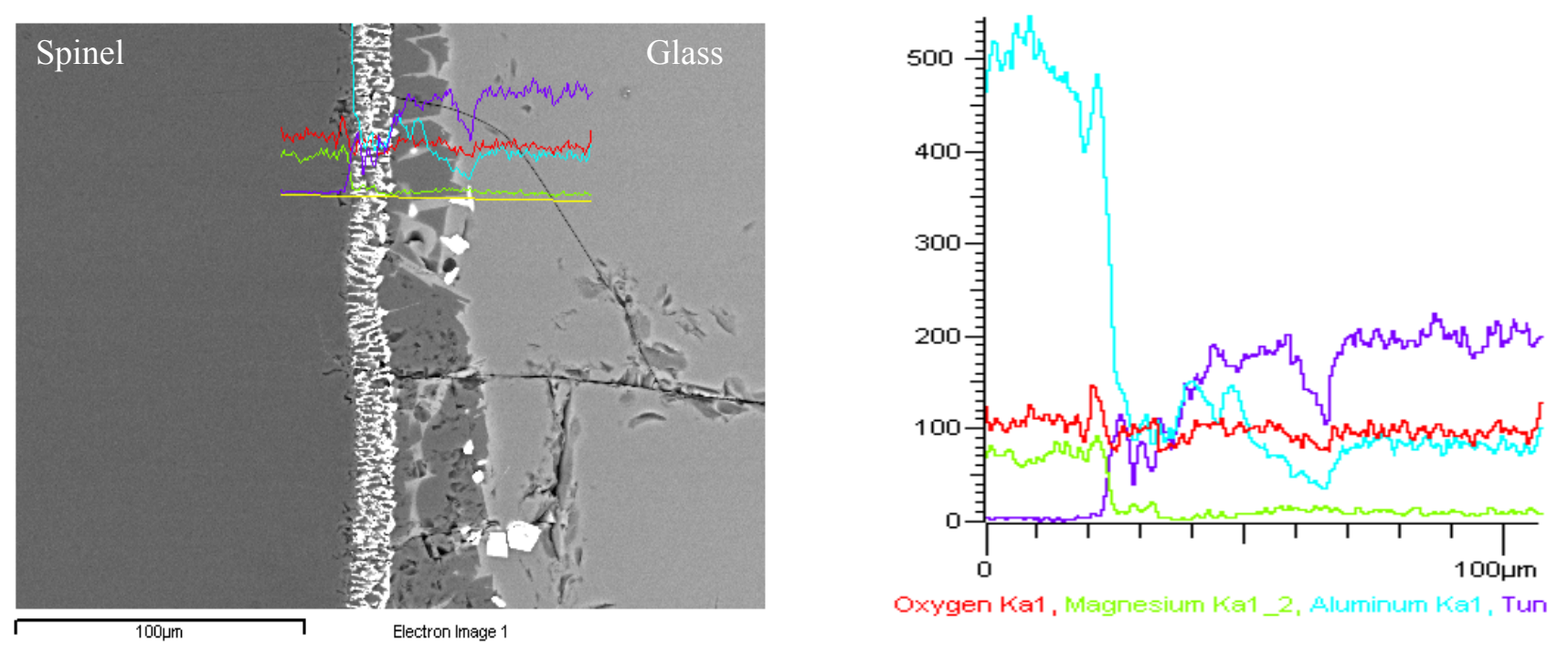

Figure A.20. SEM (Left) - Line EDS (Right) of $\mathrm{WO}_{3}$ in $\mathrm{MS}-7\left(900^{\circ} \mathrm{C} / 23 \mathrm{~h}\right)$ 
No. of

Copies

OFFSITE

2 U.S. DOE / Office of Scientific and Technical Information

1 DOE Idaho Operations Office

750 DOE Place, MSIN: 1145

Idaho Falls, ID 83402, Attn:

Kieth Lockie

15 Bechtel BWXT Idaho, Inc. (BBWI)

P. O. Box 1625

Idaho Falls, ID 83415, Attn:

A. K. Herbst

J. D. Herzog

J. L. Law

A. L. Olson

W. B. Palmer

J. Rindfleisch

T. A. Todd

J. H. Valentine

\section{Distribution}

No. of

Copies

OFFSITE

1 ENVITCO, Inc., Attn:

David M. Bennert

2 GTS Duratek Inc., Attn:

B. W. Bowan

Will Eaton

1 Southwest Research Institute, Attn:

Vijay Jain

\section{ONSITE}

MS 5218

MS 3710

MS 5218

MS 5218

MS 3211

MS 5218

MS 5218

MS 3211

DOE Richland Operations Office

P. O. Box 550, MS: K8-50

Richland, Washington 99352

T. P. Pietrok

DOE/Office of River Protection

22 Westinghouse Savannah River Co.

SRTC, Bldg 773-A

Aiken, South Carolina 29808, Attn:

D. F. Bickford

999-W

T. B. Calloway

704-1T

William E. Daniel, Jr.

704-1T

R. J. O'driscoll

704-30S

R. F. Edwards

704-25S

J. T. Gee

704-25S

C. R. Goetzman

$773-\mathrm{A}$

E. K. Hansen

704-T

E. W. Holtzscheiter

$773-\mathrm{A}$

D. C. Iverson

704-30S

W. D. Kerley

$704-\mathrm{S}$

J. C. Marra

$773-43 \mathrm{~A}$

S. L. Marra

999-W

D. K. Peeler

$773-43 \mathrm{~A}$

C. T. Randall

$773-42 \mathrm{~A}$

F. G. Smith

$774-42 \mathrm{~A}$

M. E. Smith

$773-43 \mathrm{~A}$

D. Witt

999-W

J. R. Zamecnik

$773-41$

K8-50

R. Carreon H6-60

$1 \quad$ CH2M Hill Hanford Group, Attn:

K. A. Gaper L4-07

$3 \quad$ Washington Group

J. M. Perez

$\mathrm{H} 4-02$

E. V. Morrey

$\mathrm{H} 4-02$

C. A. Musick

$\mathrm{H} 4-02$

32 Pacific Northwest National Laboratory

W. F. Bonner K9-14

T. M. Brouns K9-69

J. L. Buelt K9-09

W. L. Kuhn K7-15

R. L. Gilchrist K9-91

R. W. Goles K6-24

L. M. Peurrung K2-50

G. L. Smith K6-24

H. D. Smith K6-24

S. K. Sundaram (10) K6-24

J. S. Tixier, Jr. K6-24

J. D. Vienna K6-24

J. H. Westsik K9-91

B. J. Williams (TFA)(8) K9-69

Tech. Report Files (2) P8-55

Distr. 1 